\author{
UNIVERSIDADE DE SÃO PAULO \\ FACULDADE DE FILOSOFIA, LETRAS E CIÊNCIAS HUMANAS \\ DEPARTAMENTO DE FILOSOFIA
}

\title{
RAZÃO E SENSAÇÃO NO TEETETO DE PLATÃO
}

\author{
Anderson de Paula Borges
}

São Paulo, agosto de 2009 
Anderson de Paula Borges

\section{Razão e Sensação no Teeteto de Platão}

Tese de Doutorado apresentada ao Departamento de Filosofia da Faculdade de Filosofia, Letras e Ciências Humanas da Universidade de São Paulo para a obtenção do título de Doutor.

Orientação: João Vergílio Gallerani Cuter Agência Financiadora: FAPESP/SP

São Paulo, agosto de 2009. 


\section{Dedicatória}

À memória de minha mãe, Jurema Tavares, pela confiança no fruto do seu ventre e pelo amor que sempre nutriu pelos estudos. 


\section{Índice}

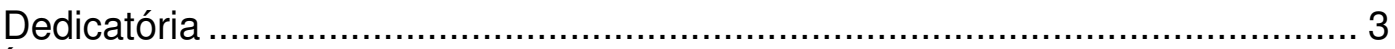

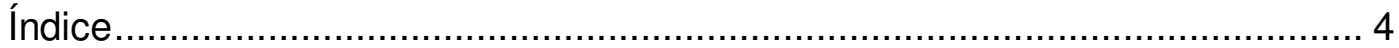

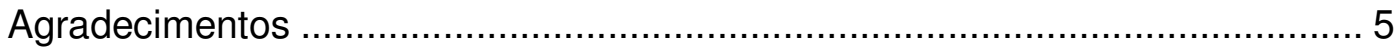

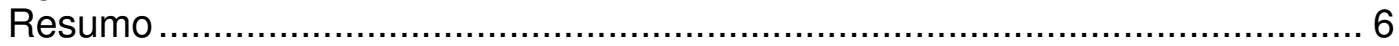

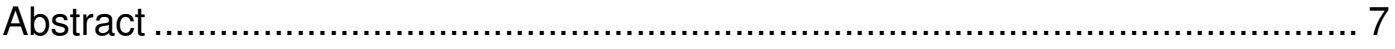

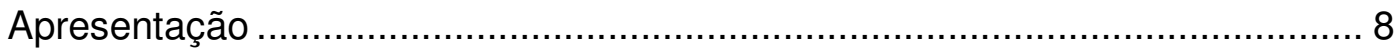

Capítulo I - Introdução .......................................................................... 10

1.1 O significado do retorno ao espírito socrático .................................. 10

1.2 O significado da Digressão Filosófica ................................................ 13

Capítulo II - Razão e Sensação em Protágoras ........................................ 22

2.1 Linhas de análise do Teeteto ........................................................ 22

2.2 A interpretação do mobilismo ..................................................... 25

2.3 Platão e o mobilismo do Teeteto ..................................................... 28

$2.4 \mathrm{O}$ argumento mobilista de Protágoras.............................................. 30

2.5 Ousia em Protágoras ..................................................................... 31

2.6 O programa da doutrina decreta .................................................. 39

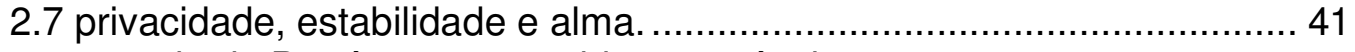

2.8 a teoria de Protágoras e os objetos estáveis . ..................................... 45

Capítulo III - Razão e Sensação em 184-6 ............................................... 50

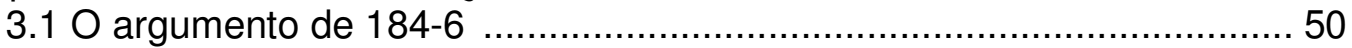

3.2 O sentido de aisthesis e a análise de Cooper ..................................... 55

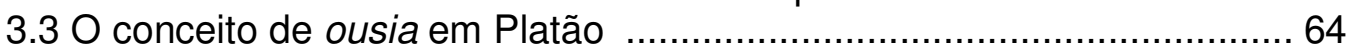

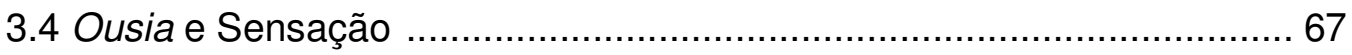

3.5 A confiança no procedimento das definições .................................... 70

3.6 A rejeição das espécies de conhecimento ........................................... 74

3.7 Separação entre razão e sensação no Fédon .................................... 77

Capítulo IV - Razão e Sensação na segunda parte do Teeteto...................... 79

4.1 Identidade e Predicação: entre o Teeteto e o Sofista ............................. 79

$4.2 \mathrm{O}$ argumento da segunda parte do Teeteto e a tese de Russell ............. 86

4.3 Análise do argumento da segunda parte ........................................... 90

4.4 A interpretação de PF na literatura secundária ................................ 93

4.5 Saber total, acquaintance model e saber efetivo ............................... 96

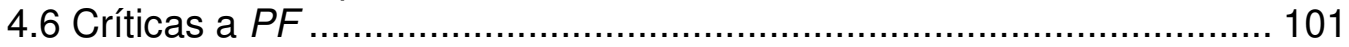

4.7 Solução do problema da opinião falsa .......................................... 110

Capítulo V - Razão e Sensação na terceira parte do Teeteto ....................... 111

5.1 Logos e composto na teoria do sonho ............................................ 112

5.2 A perceptibilidade dos elementos .............................................. 122

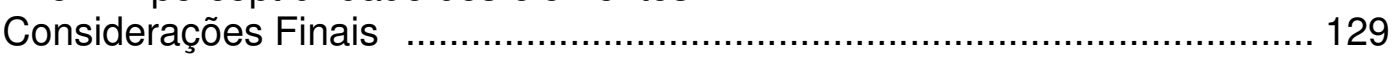

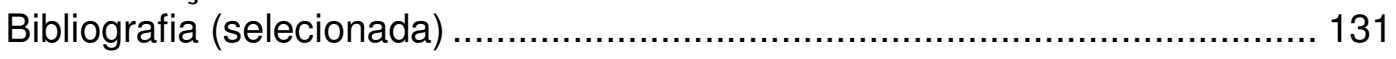




\section{Agradecimentos}

À FAPESP, pela bolsa de doutorado.

À minha mulher, Laudicéia, pela convivência, pelo amor e por compreender as exigências dessa pesquisa, sobretudo no momento que estive ausente do país.

Agradeço muitíssimo ao João Vergílio, pela orientação e confiança que sempre depositou no meu trabalho.

Ao Marco Zingano, pelo trabalho que faz na Usp em filosofia antiga e por ter me encaminhado para Oxford.

Aos colegas e orientandos de filosofia antiga da USP.

À professora Gail Fine, pela acolhida em Oxford e pelos comentários a partes desse trabalho. Ao professor Paolo Crivelli, pela acolhida.

Agradeço aos demais membros da minha família, especialmente à Jaque, pelo apoio em vários momentos.

Aos professores Roberto Bolzani e José Carlos Estêvão.

Aos amigos Carlos Eduardo e Ricardo Luiz de Mello. 


\section{Resumo}

Neste trabalho argumento que o Teeteto é um diálogo sobre a relação entre o conceito de razão, entendido como uma potência específica da alma, e a sensação, compreendida como um processo inconsciente do corpo. No primeiro capítulo examino a análise platônica da epistemologia protagoreana. Tento mostrar que nesta seção Platão não está argumentando uma tese platônica sobre o mundo sensível. Ele está explicando e criticando os princípios fundamentais da epistemologia protagoreana. No final da seção Platão explica a distinção entre razão e sensação. Na análise da segunda parte defendo que a massa de argumentos dessa seção formula uma tese platônica sobre a essência do conhecimento. Por fim, no comentário da terceira definição examino o conceito de logos da teoria do sonho e o significado da tese de que os elementos são perceptíveis. 


\begin{abstract}
In this work I argue that the Theaetetus is a dialogue about the relation between the concept of reason, understood as a kind of power of the mind, and perception, viewed as an unconscious process of the body. In the first chapter I examine Plato's analysis of Protagorean epistemology. I try to show that in this section Plato is not arguing his own view about the sensible world. He is, rather, explaining and criticizing the fundamental principles of the protagorean epistemology. At the end of this section Plato explains the distinction between reason and perception. In my analysis of the second part, I argue that the mass of arguments of this section formulates a platonic thesis about the essence of knowledge. Finally, in my commentary of the third definition, I examine Dream's concept of logos and the meaning of the thesis that the elements are perceivable.
\end{abstract}




\section{Apresentação}

O presente trabalho sobre o Teeteto tem duas características óbvias na estrutura do texto. Por um lado, procuro aproximar o diálogo de alguns argumentos da República, especialmente 523-5. De outro, tento entender como Platão trabalha o tema razão e sensação na estrutura do diálogo. Em linhas gerais, o Teeteto é uma análise das razões pelas quais devemos rejeitar as teses que manifestam alguma forma de mistura (кра̂бıs) entre razão e sensação. Parece-me que o núcleo da concepção das idéias em Platão depende dessa separação. A diferença entre o que é sensível e o que é inteligível é fundamental, sobretudo, para a consistência do conceito platônico de Forma. O Teeteto reafirma a separação entre razão e sensação, embora não mencione nominalmente as Formas.

Quanto à epistemologia da República, eu não ofereço uma análise, pois isso demandaria uma preparação mais específica. Mas vou argumentar algumas interpretações sobre certas teses que estão no corpo da obra e cujo significado será, aos poucos, esclarecido no presente trabalho. Uma destas teses é a noção de Forma ( $\epsilon \hat{i} \delta o s)$. Outra é a noção de definição como fórmula

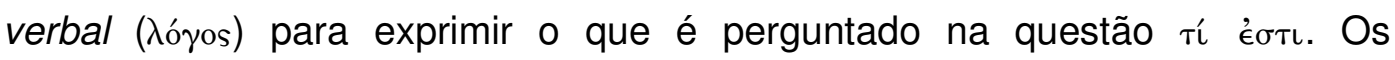
referentes do primeiro e do último compõem classes distintas. Provavelmente as Formas compõem uma classe menor que a classe que engloba os itens passíveis de definição ${ }^{1}$ e, certamente, uma Forma representa uma entidade real, enquanto que a definição é um procedimento investigativo e lingüístico que visa exprimir o elemento essencial da Forma ou de qualquer outro item. No Teeteto Platão dá grande ênfase ao aspecto unitário da definição, na abertura do diálogo, enquanto que o referente de "Forma" é ignorado em todo o texto.

\footnotetext{
${ }^{1}$ Parmênides 130c-d parece não admitir Formas para certos itens. República 596ass formula Formas para artefatos, mas Aristóteles (Met. I, 9) diz que artefatos não estão incluídos na Teoria das Formas de Platão.
} 
Uma menção tímida, talvez, é feita por meio do conceito que Platão cita em 184-6: os koiná (aspectos comuns).

Mas o tópico que dá corpo ao presente trabalho é a relação entre razão $e$ sensação no Teeteto. Considero que essa relação é o tema central do diálogo, embora não seja o único aspecto relevante. Meu trabalho procura mostrar que o tema aparece nas três seções principais: (1) 151-186; (2) 187-200; (3) 201210.

$\mathrm{Na}$ análise da primeira seção dou especial atenção ao exame da estratégia de Platão no tratamento de Protágoras, sobretudo no que Platão está propondo na passagem conhecida como Doutrina Secreta (151-6), no tema do mobilismo e no argumento de 184-6. Uma atenção redobrada é dada à última passagem. Envolvo-me ali com uma análise da interpretação de J. Cooper. O que tenho a dizer é crucial para firmar a relação entre as teses de 184-6 e República 523-5, na minha interpretação.

O tema razão e sensação é estudado também na análise da segunda parte do diálogo, onde meu exame, comparado à crítica recente, é conservador. Durante certo período de preparação do trabalho procurei ler essa seção sob a perspectiva sugerida pela maioria da crítica: o tópico do falso estaria atrelado às aporias de uma definição de conhecimento como opinião verdadeira, o que explicaria seu aspecto inconclusivo. $\mathrm{O}$ exame teria a função de mostrar que a estreiteza lógica dessa definição é incompatível com uma explanação da natureza do erro. Embora eu considere que Platão está, de fato, argumentando a simplicidade lógica do conceito de doxa, recentemente me convenci de que esse aspecto não representa todo o argumento de Platão. Há a possibilidade de que a segunda parte do Teeteto manifeste em sua trama um argumento platônico sobre as exigências do conceito de conhecimento.

Por fim, apresento um comentário da teoria do sonho. Não me dedico ao exame de todos os aspectos da terceira seção. O que me interessa é a tese nuclear da teoria do sonho, a chamada assimetria cognitiva. Procuro verificar em que medida essa assimetria nos ensina algo sobre o conceito de logos que é operativo na teoria. O tema razão e sensação aparece na análise que proponho do aspecto sensível dos elementos na teoria do sonho. 
Antes de entrar no exame do corpo principal de teses do diálogo, gostaria de dizer alguma coisa sobre algumas tendências de interpretação do Teeteto.

\section{CAPÍTULO I}

\section{INTRODUÇÃO}

\subsection{O significado do retorno ao espírito socrático na investigação do conhecimento.}

Quero examinar um aspecto que tem se tornado relevante na crítica recente do Teeteto, o suposto retorno ao socratismo, a perspectiva cognitiva do mundo que ainda não é moldada por uma metafísica platônica. A preocupação em resolver o problema da ausência, no Teeteto, de uma metafísica dos diálogos médios, levou alguns intérpretes a uma tentativa desesperada de resolver a situação por meio da seguinte hipótese: Platão escreve o Teeteto sob a influência da lógica socrática do ‘̋ $\lambda \in \gamma$ xos, por isso ele não desenvolve teses metafísicas no diálogo. ${ }^{2}$

É importante estabelecermos a medida exata desse aspecto socrático do Teeteto. Para tanto, examinemos alguns traços "dramáticos". O diálogo é uma conversa entre Sócrates e os matemáticos Teeteto e Teodoro. Quando estamos lendo esta conversa nossa posição no diálogo já deixou para trás uma cena preliminar do Prólogo ${ }^{3}$ : Euclides e Terpsion se encontraram em Mégara para trocar elogios sobre Teeteto, comentar as circunstâncias de sua morte e

\footnotetext{
${ }^{2}$ Cf. Sedley, D., The Midwife of Platonism. Oxford: OUP, 2004; LONG, A.A., 'Plato's Apologies and Socrates', in: GentZleR, J., Method in Ancient Philosophy. Oxford: OUP, 1998, pp. 113136.

${ }^{3}$ Há alguma discussão sobre o Prólogo do Teeteto em CoRnFORD, F.M., Plato's Theory of Knowledge. London: Routledge \& Kegan Paul, 1951 [1935], p. 15; StERN, P., Knowledge and Politics in Plato's Theaetetus. New York: CUP, 2008, pp. 12-31; SEDLEY, 2004, pp. 15-19;
} 
mencionar o encontro entre o jovem matemático e Sócrates, em algum momento de 399 a.C. Apesar do aspecto fictício da cena, há detalhes importantes aí. O texto principal da obra, escrito por Euclides, é na verdade um relato escrito da conversa entre Teeteto, Teodoro e Sócrates, conversa esta que forma o corpo principal do diálogo. Conforme o Prólogo nos conta, esse texto foi supervisionado diretamente por Sócrates. Muitas vezes se costuma lembrar que há uma instância disso no Banquete, pois Apolodoro também consulta Sócrates para averiguar a exatidão do relato de Aristodemo sobre o encontro de Sócrates com os participantes do Banquete (cf. 173b). Contudo, no Banquete Apolodoro parece ter consultado Sócrates somente uma vez, enquanto que, no Teeteto, a redação de Euclides é retomada com Sócrates em mais de uma ocasião.

Há uma conexão "moral" entre esse trabalho de revisão e o contexto da condenação de Sócrates. Embora o diálogo não informe quando Euclides esteve com Sócrates, limitando-se a dizer que foi pouco tempo antes de sua morte (142c7-8), há evidências de que os encontros poderiam ter ocorrido no cenário da prisão, tanto dentro da cela como nos arredores, em algum momento não muito distante dos procedimentos da acusação. Tudo isso pode ser fruto da imaginação de Platão, é verdade, mas lembremos que Platão é conhecido por dominar a arte de misturar dados históricos da vida de Sócrates com a trama fictícia de seus diálogos. Há sempre algo a se notar aí.

Há duas datas dramáticas no diálogo que nos permitem retirar alguma informação. A primeira é a data da conversa entre Euclides e Terpsion, provavelmente ocorrida cerca de 30 anos após os eventos narrados, em algum momento próximo à época da composição. Podemos estabelecer isso do seguinte modo. Euclides menciona que viu Teeteto sendo carregado, de Corinto para Atenas, com um ferimento de guerra (142b). Isso revela que o Teeteto que está ali já não é mais aquele jovem com menos de 18 anos que participa do diálogo, mas deve ser uma pessoa madura. Quanto à segunda data, trata-se do momento em que o diálogo efetivamente se desenvolve: no 
ginásio de Atenas em 399. Ao contrário da data de composição, ${ }^{4}$ admitida em torno de 369, mas sem evidências definitivas, temos certeza da segunda data dramática por causa de duas circunstâncias citadas no texto: (i) na cena inicial Euclides conta que Sócrates conheceu Teeteto "ainda adolescente" (142c); (ii) depois, no desfecho do diálogo, Sócrates diz que precisa ir ao pórtico do rei para tratar da acusação de Meleto (210d). ${ }^{5}$ Tomando estas duas informações como pontos distintos num tempo cronológico, ainda que o corpo que as contenha seja um diálogo imaginário, o fato é que os dois momentos indicam que a conversa entre Sócrates e Teeteto ocorre às portas do julgamento, quando Teeteto ainda é um adolescente.

Imaginemos que Platão está organizando em sua mente a ordem cronológica das duas cenas dramáticas. Ele precisa vincular a correção de Sócrates às visitas de Euclides a Atenas de um modo que não viole, nem a seqüência dos acontecimentos de 399, tampouco a data na qual ele está situando a conversa dos megáricos. O problema é que, entre o momento que

\footnotetext{
${ }^{4}$ A maior parte dos comentadores situa a composição do Teeteto em torno a 369 a.C. As razões são as seguintes. O Teeteto abre com a cena em que o jovem matemático é levado de Corinto para Atenas. Ele está ferido e doente devido à "guerra", mas o diálogo não diz qual. Se pudermos identificar a batalha na qual Teeteto participou, podemos obter alguma informação sobre a data de composição. Diés (1926, Notice) relata que os intérpretes se dividem entre dois episódios: a batalha de Neméia, ocorrida em 394, e os combates no istmo, quando Atenas se alia a Esparta contra Tebas, por volta de 369. O problema de aceitar a primeira data é que haveria um espaço de tempo muito estreito entre a morte de Sócrates - data dramática da conversação que constitui a essência do diálogo - e o relato de Euclides, que é um relato escrito, preparado por Euclides e lido por seu escravo. É essa leitura que forma o texto principal do Teeteto. O problema da exigüidade das duas datas não é tão grave, pois Euclides poderia muito bem retratar o que Sócrates the contou em pouco tempo, bastando para tanto recordar-se de um conteúdo que em 394 ainda seria relativamente recente. Mas Diès argumenta que, neste caso, o recurso fictício à composição feita por Euclides seria inútil, pois a função dessa composição é, precisamente, permitir a conexão entre os acontecimentos de 399 e um tempo distante, este no qual estão Euclides e Terpsion. Diès opta, então, pela data de 369. Essa data é hoje aceita pela maior parte dos intérpretes, entre os quais Burnyeat (Burnyeat, M. F., The Theaetetus of Plato. Indianapolis/Cambridge: Hackett ,1990) e Cornford (1935). Mas há discordâncias. Ver Sedley, 2004, p. 1, n. 1.
}

${ }^{5}$ Cf. LONG, 1998, p. 121. 
se dá o encontro de Sócrates com os matemáticos e o dia da morte do primeiro, há um espaço de tempo muito curto para que Euclides possa visitar Sócrates e corrigir o material do diálogo. Como Euclides teria feito seu trabalho nestas circunstâncias?

Há três possibilidades. As correções teriam acontecido: (1) na cela; (2) em algum momento durante o processo de acusação ou 3) em momentos complementares que envolvem (1) e (2). Para decidir temos dois dados relevantes. Primeiro, de acordo com o Fédon Euclides e Terpsion estavam entre os que assistiam Sócrates no leito de morte (cf. Fédon 59c). É bem plausível que Platão imagine que Euclides possa realizar o trabalho de revisão neste momento. O segundo ponto é que Sócrates esperou um mês pelo cumprimento da sentença, pois, ainda segundo o Fédon, sua condenação coincide com o período no qual Atenas festeja o êxito de Teseu em Creta. Durante estes festejos as execuções são interrompidas até que o navio ateniense retorne da ilha. Portanto, trata-se de um período de tempo mais do que suficiente para Euclides corrigir com Sócrates seu relato do Teeteto.

Tenho inclinação pela terceira opção. Penso que Platão prevê que Euclides trabalhe o texto com Sócrates principalmente na cela, embora nada impeça que parte da correção fosse feita momentos antes da prisão. Seja como for, esse trabalho não poderia ser realizado num momento muito distante da acusação, pois Sócrates termina o diálogo se dirigindo ao pórtico do rei. É a partir desse momento, quando a conversa já se concretizou, que ele poderia ter encontrado Euclides.

Nestas circunstâncias, temos: (i) um diálogo sobre o conhecimento; (ii) corrigido diretamente por Sócrates e (iii) no contexto de sua morte. Há algum significado nisso para a interpretação do diálogo? A resposta talvez esteja na Digressão Filosófica.

\subsection{O significado da Digressão Filosófica.}

A diferença entre o conhecimento socrático e os conhecimentos parciais ou domésticos da vida de Atenas constitui a atmosfera da chamada Digressão 
Filosófica. (172c-177b, daqui para frente apenas Digressão). Há um interesse todo especial de parcela da crítica do Teeteto na Digressão. É compreensível, pois se trata do único momento do diálogo em que, supõe-se, o espírito da doutrina das Formas parece entrar, sorrateiramente, na massa de argumentos que examina a epistemologia protagoreana. Entre vários aspectos, a Digressão menciona a importância de nos assemelharmos a deus em conhecimento. Seria um sinal de que o Teeteto não está distante do centro de gravidade da metafísica platônica? ${ }^{6}$

Para David Sedley o Sócrates do Teeteto é um arauto da metafísica platônica que ainda não se entregou totalmente a ela porque permanece ligado ao programa do é $\lambda \epsilon \gamma \chi$ os, com sua filosofia terapêutica, voltada ao esclarecimento dos interlocutores. Por causa desse programa, o texto do Teeteto mantém-se relativamente comedido no aspecto ontológico e nas referências às teses da República. Mas na Digressão, lembra Sedley, o autor do Teeteto recorda a distinção entre o conhecimento divino e o conhecimento humano que está na base de sua metafísica. ${ }^{7}$

Essa menção à metafísica platônica precisa ser qualificada, mas não vou discuti-la. A interpretação de Sedley é um dos poucos tratamentos justos dados à Digressão. Geralmente essa passagem é ignorada pelos comentadores, sobretudo na interpretação analítica. Contudo, tenho uma divergência com a análise de Sedley. Nela está subentendida uma tese por meio da qual Sedley lê todo o diálogo: o Teeteto presta homenagem a um Sócrates não-metafísico que conduz a investigação sobre o conhecimento sem se envolver com teses positivas. Não creio que Platão tenha exercido esse difícil despojamento de suas teses da República, e de outros diálogos, para escrever o Teeteto. Conforme o interpreto, o espírito socrático não é uma "fase"

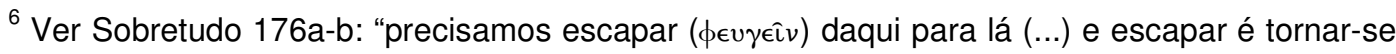

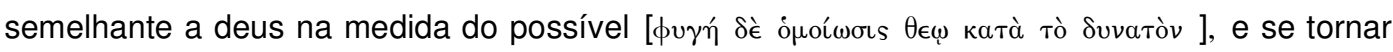

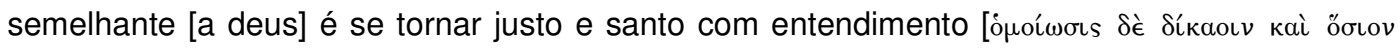
$\left.\mu \in \tau \grave{\alpha} \phi \rho o v \eta ́ \sigma \epsilon \omega s \quad \gamma \in v \in \sigma_{\sigma} \theta a u\right]$

${ }^{7}$ Cf. Sedley, 2004, pp. 62-86.
} 
do autor dos diálogos que, na velhice ${ }^{8}$, Ihe provoca saudosismo e o faz moldar o Teeteto sob o impacto dessa experiência. Entendo que o espírito socrático é um aspecto sempre atual em Platão. A monumental obra de Gregory Vlastos sobre a epistemologia socrática não desautoriza essa conclusão, pois um filósofo pode progredir dogmaticamente - pode incrementar seu manancial de convicções - e ainda assim manter uma fé no método terapêutico do exame de teses. No caso de Platão, mesmo que aceitemos, como a maior parte da crítica, que o Mênon é o texto onde Platão começa a acrescentar novas colunas ao edifício do ‘́ $\lambda \epsilon \gamma \chi{ }^{\circ}$, nem todos os aspectos que se vinculam de modo histórico a Sócrates são incompatíveis com parte desse programa.

D. Sedley e F. Cornford acham que a Digressão menciona implicitamente as teses da República. Mas eu não concordo. O programa da República não precisa ser invocado - mais do que qualquer outro diálogo sempre que um texto platônico sugere distinções ontológicas ou níveis de entendimento no campo moral ou político.

A Digressão pode ser lida como uma passagem na qual o autor do Teeteto está argumentando, contra Protágoras, a partir de uma perspectiva moral. Essa perspectiva tem um forte apelo unitário na medida em que rejeita a

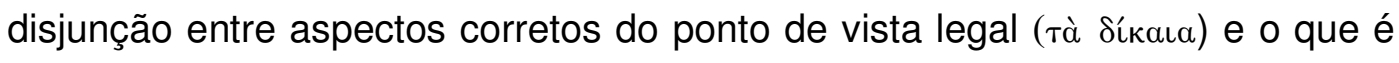
objetivamente vantajoso ( $\left.\sigma u \mu \phi e^{\prime} \rho o v\right)$. Essa disjunção é o elemento-chave do argumento, como veremos adiante. De outro lado, se é o caso de lermos o Teeteto a partir do programa da República, o diálogo como um todo pode ser interpretado a partir de alguns pontos nucleares dessa doutrina, mas isso demandaria demonstrações que não posso apresentar aqui.

Eu concordo, porém, com Cornford quando ele diz que o tema central da Digressão é contraste entre uma perspectiva filosófica que se ampara numa ontologia unitária e o discurso forense ou político, que se adapta às circunstâncias. $^{9} \mathrm{Na}$ Digressão Platão mostra que uma forma de

\footnotetext{
${ }^{8}$ Se Platão (428-347) escreveu o Teeteto por volta de 369 a.C. (ver nota 02), ele está próximo dos 60 anos e já tem umas 20 obras escritas.

${ }^{9}$ CORNFORD, 1935, p. 89.
} 
protagoreanismo permite justificar isso. Essa diferença se revela no contraste entre o filósofo e o orador, um contraste bastante explorado pela Digressão. 0 efeito mais terrível desse contraste foi a morte de Sócrates.

A Digressão mostra que a complexidade da questão sobre o conhecimento tem implicações num programa moral. Esse programa, no entanto, não pode ser plenamente desenvolvido no Teeteto, pois o diálogo já está engajado no tema epistemológico. A Digressão está ali para lembrar que o exame do conhecimento em Protágoras não é sem conseqüências para as questões éticas. Note-se, a esse respeito, que a epistemologia protagoreana referenda o ponto de vista de que os valores são relativos. A Digressão argumenta que essa linha não se limitará a justificar os predicados sensíveis sobre as propriedades da experiência comum com as coisas. Ela também será considerada válida no campo moral e político. A Digressão, nesse sentido, deve ser lida junto com a Apologia de Sócrates. Desse modo seriam lembradas as conseqüências do vínculo, aparentemente inocente, entre relativismo e política.

A Digressão pode ser lida sob a perspectiva da Apologia em vários aspectos. O Teeteto retrata um Sócrates que não tem propriamente uma definição formal de conhecimento, mas percebe uma série de equívocos e inconsistências em várias definições correntes. Especialmente no tipo de postura que se esperava dele ao se dirigir aos juízes ou às pessoas que assistiam a seu julgamento, Sócrates percebeu a inevitabilidade desse conhecimento negativo. A Digressão mostra que o saber filosófico se opõe a algumas atitudes típicas nos tribunais, entre as quais a fala marcada por tempo, a adulação dos juízes e a resposta precisa aos artigos da acusação (cf. 172d-173b).

Rachel Rue nota que na Digressão Sócrates retrata o filósofo sob o signo na inabilidade política: "é particularmente apropriado Sócrates escolher o tribunal como cenário da 'aparência ridícula' do filósofo, já que, como sabemos pelo prólogo, ele está prestes a entrar na sala de audiência." ${ }^{10}$ A Digressão

\footnotetext{
${ }^{10}$ RUE, R., 'The Philosopher in Flight: the Digression (172c-177c) in Plato's Theaetetus', Oxford Studies in Ancient Philosophy, 11 (1993), pp. 71-100, aqui p. 75.
} 
mostra que o filósofo é inábil no tribunal porque não reconhece os rituais do jogo político. É provável que Platão não aprove o retrato do filósofo que o Teeteto oferece, uma caricatura do pensador idealista que desconhece as questões da vida da cidade, mas o texto da Digressão é muito claro sobre o abismo intelectual que separa "os dois coros" (173b): o dos filósofos e o dos oradores.

Examinemos como essa diferença é mais uma das conseqüências da tese de Protágoras. Do ponto de vista da ordem dos argumentos, a Digressão está inserida num conjunto de 12 objeções à tese protagoreana. Estas objeções se iniciam em 161b, com a referência à anphidromia da tese. Antes da Digressão, são 9 argumentos: (1) objeção da percepção dos animais (160e2-161d2); (2) objeção da pesquisa filosófica (161d3-162a2); (3) objeção da percepção dos deuses (162a4-162d2); as respostas de Protágoras às três primeiras (162d3-163a6); (4) objeção da linguagem e do alfabeto (163a7-c5); (5) objeção da memória (163c5-165a3); (6) objeção do olho coberto (165a4165d2); (7) objeção dos advérbios (165d2-e4); segue a Defesa de Protágoras (165e4-168c2) onde o sofista responde aos argumentos anteriores nesta ordem: 5, 6, 1, 2, e 7; (8) objeção chamada peritropē (168c2-171c7) ou autorefutação; (9) objeção sobre o divórcio entre benefício e justiça (171c7-172b9); a Digressão (172c1-177b8); (10) objeção das especialidades (177b8-179b9); (11) objeção do mobilismo (179c1-183c2) e a refutação final sobre a distinção entre percepção e conhecimento (183c3-187a9).

Não é possível, obviamente, tratarmos dos detalhes destes argumentos. ${ }^{11}$ Mas a descrição da estrutura da crítica permite perceber que a Digressão se segue à nona objeção: a proposição do divórcio entre justiça e benefício. A crítica a esta posição principia de modo indireto, sendo explícita somente na Digressão. Inicialmente, a crítica se apresenta sob a forma de uma nova defesa de Protágoras. Tendo concluído a análise da oitava objeção, o argumento da auto-refutação, Sócrates diz que o ataque a Protágoras foi muito violento (171c7). É preciso retomar o dito a partir de uma base "mais sólida".

\footnotetext{
${ }^{11}$ Para uma análise de todas as objeções na ordem que aparecem no texto ver CHAPPELL, T., Reading Plato's Theaetetus. Indianapolis/Cambridge: Hackett, 2005, sobretudo pp. 86-149.
} 
Reelaborando os elementos da Defesa de Protágoras (166d-167a), Sócrates divide o dito em dois níveis: em matéria de sensações, o que percebemos é o que define o ser de cada objeto. Chamemos essa posição de (a). De outro lado, se Protágoras admitir que existem casos nos quais alguns homens são superiores a outros, ele deve estar preparado para conceder isso em assuntos como saúde ou política. Chamemos a última posição de (b).

Sócrates argumenta os dois níveis do dito da seguinte forma. Primeiro, na esfera política temas como justo e injusto, o que é aceitável religiosamente ou não, honra, etc., são valores que as cidades podem conceber segundo os parâmetros do relativismo sensível que temos em (a). É um relativismo dentro de um regime político. Sobre tais temas não há critérios objetivos e as cidades ou os indivíduos julgam conforme suas inclinações (cf. 171e-172). Mas suponha que se trata de decidir acerca do que é vantajoso (ovvф́́pov) no interesse da cidade. Neste caso estamos no terreno de (b), isto é, não é correto proceder da mesma forma que na situação anterior, onde os valores são relativos. Isso significa que Sócrates reclama que haja pelo menos uma classe de valores que as cidades precisam considerar conforme um critério objetivo de verdade. Sócrates, evidentemente, não aceita essa visão porque ele não limita desse modo os valores, mas ele não critica diretamente isso nesta parte do diálogo. O que então o teria levado a conceder uma plausibilidade provisória ao protagoreanismo no campo político?

Penso que a concessão se justifica porque a intenção de Sócrates é mostrar as conseqüências desta posição na Digressão e no que a segue. Antes da Digressão ele trabalha com o dito naqueles dois níveis que mencionei. O primeiro nível é o núcleo da tese protagoreana, núcleo este que tem por essência uma tese cognitiva baseada na sensação como critério. No texto Sócrates passa dos predicados sensíveis quente, seco, doce para os predicados justo e injusto num único passo, propondo que os últimos sigam a mesma lógica dos primeiros no âmbito da cidade. Todavia, quando cita o tema do que é vantajoso, Sócrates retém a perspectiva da objetividade.

A linha geral dessa análise da Digressão está propondo o seguinte. Sócrates concede aos sujeitos da epistemologia protagoreana a possibilidade 
de sustentarem suas convicções conforme a demanda particular ou social nas cidades, ao mesmo tempo que procura garantir para o Estado uma esfera mínima de valores em torno do que é benéfico e prejudicial. É esse o sentido do "vantajoso". Temos aqui, explicitamente, um divórcio entre justiça e benefício que, como afirma Chappell ${ }^{12}$, não é muito diferente da distinção entre prudência política e moral na sociedade moderna.

Alguns comentadores notam que não é clara a posição de Sócrates sobre esse divórcio. Contudo, penso que a Digressão indica que Sócrates se mantém numa defesa da perspectiva cognitiva para os temas da vida política, sem dar detalhes dessa posição. Na Digressão Sócrates defende que é mais apropriado pensar aqueles temas (justiça e bem) num processo de investigação que aproveita o tempo de estudo, do que concebê-los no ritmo agitado e rigidamente controlado da cena política. É por isso que o primeiro assunto da Digressão é a diferença entre o tempo de que dispõem os filósofos e o tempo dos oradores. Na primeira frase da Digressão, em 172c1, Sócrates menciona que os filósofos gozam de scholē, a disponibilidade de tempo. Notese que scholē é a mesma palavra usada por Euclides no Prólogo, ao relatar que "quando tinha tempo" trabalhava no texto do diálogo (143a).

O tema do tempo dedicado à argumentação faz os dois interlocutores professarem uma tese sobre o alcance dos aspectos epistemológicos e o alcance dos aspectos políticos da tese de Protágoras. Sócrates diz que o aspecto político exige um exame mais demorado que o epistemológico, o que surpreende, porque o argumento epistemológico é o mais longo do diálogo (cf. 151-186). Essa tese é proferida quando Sócrates alega que o assunto a ser tratado dali em diante (na Digressão) é a "passagem de um argumento

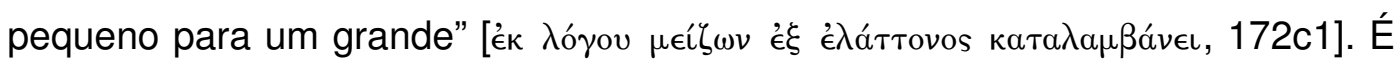
então que Todoro diz que ambos gozam de tempo para investigar o argumento mais longo. Mas não fica muito claro, à primeira leitura, a que argumento Sócrates se refere. Ao lermos a Digressão, porém, percebemos que o argumento maior é o argumento por meio do qual se desenvolve o contraste

${ }^{12}$ Chappell, 2005, p. 120. 
entre o filósofo e o orador, isto é, a tese de Protágoras sob a perspectiva política. O argumento menor, por seu turno, pode ser tanto a reelaborarão da tese, em 171c-172b, ou o conjunto da análise sobre os aspectos epistemológicos do dito, em toda a parte I do diálogo. Como já indiquei acima, penso que esse é o caso do argumento maior.

$\mathrm{Na}$ análise de Burnyeat a referência a esse argumento longo tem 0 seguinte motivo. ${ }^{13} \mathrm{O}$ edifício da sociedade entrará em colapso se aceitarmos a premissa protagoreana do saber conforme a nova defesa, ou seja, a separação entre justiça e benefício. Platão está consciente disso, mas como a demonstração do ponto exigiria uma obra nos moldes da República ou do Górgias, Platão prefere valer-se de um recurso menos argumentativo: a Digressão.

Depois da menção à scholē, Sócrates comenta que não é surpresa o fato de que os que estudam a filosofia tenham uma postura ridícula no tribunal. Para Sócrates este local é uma arena para escravos. Já os que estudam a filosofia são considerados "homens livres" (172c). A comparação dos filósofos a homens livres é defendida na afirmação de que os filósofos utilizam sua scholē para examinarem as perspectivas que os próprios argumentos impõem (cf. 172d). Eles não se perturbam pela brevidade ou extensão dos argumentos

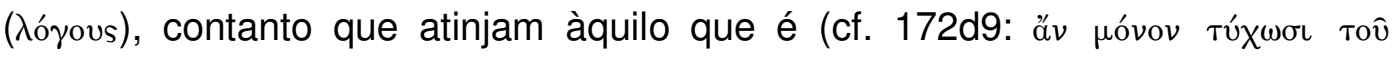
óvтos). De outro lado, os oradores são escravizados por regras rígidas no discurso. Nos casos jurídicos, precisam ler o resumo dos artigos da acusação perante o acusado (cf. 172e4) e sob o ouvido atento deste. Além disso, seus discursos são controlados pelo relógio de água e pelo juiz.

Nas porções mais centrais da Digressão o acento é sobre o alheamento do filósofo acerca de temas como o caminho da ágora, a linhagem política, a propriedade privada, as disputas por cargos e assim por diante. Sócrates diz que o filósofo está na cidade somente enquanto corpo, ecoando, talvez, o Fédon, mas também uma passagem bem conhecida da República, em 493a-

\footnotetext{
${ }^{13}$ BURNYEAT, 1990, p. 33-4.
} 
498c, onde a decadência da filosofia é atribuída ao trabalho dos sofistas. A Digressão é o testemunho de que mesmo no seio de um diálogo ocupado com questões técnicas sobre o conhecimento, Platão ainda considera que o sentido desse trabalho é firmar-se como perspectiva oposta às doutrinas que emitem

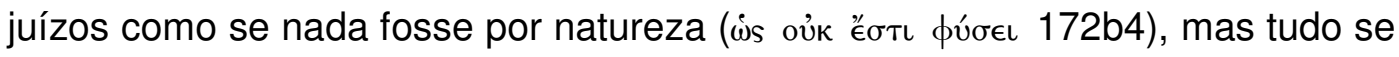
ajustasse às particularidades da política. A Digressão é um encômio à realidade daquilo que se chama, em bom platonismo, de paradigma ou ontos on.

Segundo Alex Long, parte dos diálogos de Platão demonstra que o filósofo "continua escrevendo a Apologia". ${ }^{14}$ Em cada diálogo Platão mobiliza argumentos para esclarecer a si mesmo - e à audiência filosófica - traços do pensamento de Sócrates que exercem fascínio ou que, provavelmente, ainda soam enigmáticos. No Teeteto há sinais desse projeto no Prólogo, como vimos, mas também na referência à maiêutica em 150b-151d e, pelo que argumentei acima, na própria Digressão. Se o Prólogo tem o propósito de situar o diálogo nos acontecimentos de 399, Long tem razão em destacar que o Teeteto se desenvolve sob o enigma de Sócrates. Na medida em que contribui para desvendar parte do enigma, o Teeteto pode ser compreendido como uma obra em dois níveis: uma argumentação cerrada sobre temas relacionados ao saber, de um lado, e um conjunto de referências ao contexto da vida de Sócrates, de outro.

Meu trabalho de interpretação do diálogo tem as características de uma abordagem sobre o núcleo do elo entre estes dois aspectos. Penso que esse elo é implicitamente defendido na opção platônica de escrever um diálogo sobre o conhecimento conforme os procedimentos históricos do método socrático. Uma questão relevante é como o autor da República pôde escrever um diálogo inteiro sobre conhecimento sem mencionar nada do que se costuma chamar de Doutrina das Formas. Aqui abundam hipóteses: (i) Platão nunca argumentou a teoria das Formas: (ii) ele argumentou, mas já não está

${ }^{14}$ Cf. LONG, 1988, p. 124. 
satisfeito com ela; (iii) ele vê dificuldades na teoria para explicar os problemas da participação.

Prefiro pensar que à época do Teeteto (e do Parmênides) Platão percebeu que existem aspectos problemáticos na relação entre as Formas e seus participantes. Ele deseja dar um tratamento mais crítico aos problemas mencionados acima, sobretudo quando escreve o Parmênides, o Teeteto e Sofista. Na segunda seção desse trabalho comento alguns aspectos dessa fase crítica.

Agora é o momento de examinar a primeira parte do diálogo e estabelecer as linhas gerais do argumento de Platão contra a epistemologia protagoreana.

\section{CAPÍTULO II}

\section{RAZÃO E SENSAÇÃO EM PROTÁGORAS}

\subsection{Linhas de análise do Teeteto ${ }^{15}$}

O Teeteto mostra que Platão considera relevante discutir as formas de relativismo e mobilismo que as doutrinas epistemológicas gregas defendem. Nossa análise da Digressão, no capítulo anterior, nos mostrou o aspecto político desse relativismo e os problemas que Sócrates vê nesse aspecto.

\footnotetext{
${ }^{15}$ Devido ao conteúdo predominantemente epistemológico e às evidentes antecipações de problemas típicos da epistemologia contemporânea, o Teeteto tem recebido estudos provenientes, em sua maior parte, da tradição inglesa e americana de interpretação. Nessa linha há vários livros publicados. Na leitura que apresento aqui as seguintes análises gerais, listadas em ordem de publicação, foram cruciais em meu estudo do Teeteto: (i) Plato's Theory of Knowledge (1935), de F. Cornford; (ii) Plato: Theaetetus (1973), de J. McDowell; (iii) Plato's Theaetetus (1988), de D. Bostock; (iv) The Theaetetus of Plato (1990), de M. Burnyeat; (v) The Midwife of Platonism (2004), de D. Sedley e Reading Plato's Theaetetus (2005), de T. Chappell. Entre os papers a lista de débitos é imensa, alguns dos quais serão mencionados a partir das referências feitas nas notas de rodapé.
} 
Agora é o momento de examinarmos os alicerces epistemológicos. Seria razoável começarmos por um exame do que Platão já disse sobre sua epistemologia em outros diálogos e confrontar os argumentos platônicos com as novas idéias do Teeteto, mas a relação entre o Teeteto e a obra de Platão é objeto de uma disputa entre os intérpretes. Do ponto de vista do enquadramento do diálogo no platonismo, podemos identificar duas vertentes principais de interpretação. Timothy Chappell, em sua tradução comentada do diálogo ${ }^{16}$, propõe uma classificação entre "unitários" e "revisionistas".

Os unitários defendem uma doutrina relativamente homogênea entre os tópicos dos diálogos médios (sobretudo Fédon, Banquete, Fedro e República) e o conteúdo dos chamados diálogos tardios, principalmente o Parmênides, o Teeteto, o Sofista, o Político, o Filebo e o Timeu. Os revisionistas, de seu lado, argumentam que há modificações importantes na forma como Platão se posiciona sobre seus temas clássicos nestes dois conjuntos de diálogos. Tais modificações estariam ligadas aos seguintes temas centrais: (a) relação entre

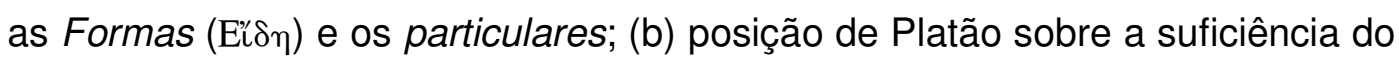
logos na definição de conhecimento (cf. Teeteto 201-210); (c) problema da estabilidade e cognoscibilidade do que é sensível; (d) problema do aspecto unitário das Formas (o que Owen e Ryle chamam o "atomismo lógico" de Platão). De certo modo, a posição comum que articula todos estes temas é a hipótese de que, entre República e Parmênides, Platão percebeu que seu conceito de Formas precisa de uma revisão. É preciso explicar como uma Forma pode cumprir dois papéis de modo consistente: (i) ser a unidade de uma multiplicidade e (ii) dar conta dos problemas da participação discutidos no Parmênides e no Sofista.

A divisão entre unitarismo e revisionismo não é exaustiva, pois há interpretações relevantes que não se alinham ao esquema. Alguns defendem um unitarismo moderado, ao mesmo tempo que reconhecerem as novidades introduzidas pelos diálogos do período pós-República. ${ }^{17}$ Por outro lado, certos

\footnotetext{
${ }^{16}$ CHAPPELL, 2005, pp. 16-24.

${ }^{17}$ Um exemplo recente de um intérprete que defende uma visão unitária do pensamento de Platão, mas reconhece as mudanças entre a dupla Fédon-República e o platonismo da tríade
} 
intérpretes da tradição analítica - tradicionalmente uma fonte de comentários revisionistas - admitem um sentido comum para o que Platão entende por Formas e não concordam que o autor dos diálogos as tenha abandonado ou substituído por alguma teoria mais sofisticada.

Embora possa ser identificado em linhas gerais, o esquema unitarismorevisionismo é pouco útil para a interpretação dos problemas específicos do Teeteto. Essa disjunção não faz justiça à complexidade do que se produz no atual corpo de papers e livros sobre a epistemologia platônica.

Tome-se, como exemplo, o seguinte caso. Na tradição analítica a obra de Gail Fine é uma referência na interpretação da epistemologia de Platão. É evidente que a interpretação de Fine partilha a tese de G. Ryle e de M. Burnyeat de que os argumentos platônicos devem ser vistos à luz daquilo que a epistemologia contemporânea discute. No entanto, quase nada do que revisionistas como Ryle argumentaram sobre o pensamento maduro de Platão permanece de pé na leitura de Fine. Em On Ideas (1993), por exemplo, ela

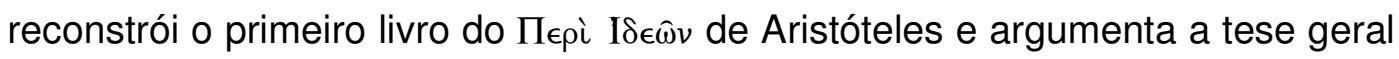
de que Platão tem problemas específicos em cada diálogo, mas que, no âmbito dos diálogos médios, a compreensão platônica da doutrina das Formas não sofre alterações, podendo ser identificada a uma tese sobre a prioridade da compreensão de propriedades naturais para o entendimento do que subjaz à realidade. Devido ao escopo de seu projeto, Fine é econômica em sua análise dos diálogos do período pós-República. Há sinais, contudo, de que ela não se alinharia à tese de que a doutrina das Formas seja muito diferente nestes diálogos.

Para um rápido delineamento de como essa questão é vista por intérpretes franceses, é útil a Introdução de Jean-François Pradeau a Platon:

Parmênides, Teeteto e Sofista é Charles Kahn em 'Why Is the Sophist a Sequel to the Theaetetus?', Phronesis 52 (2007), 33-57. Outro unitário declarado é D. Sedley (2004). A obra de Gail Fine, sobretudo FINE, G., On Ideas: Aristotle's Criticism of Plato's Theory of Forms. Oxford: OUP, 1993, é um caso mais complexo, mas considero que no conjunto esse trabalho apóia a tese unitária. 
Les Formes Intelligibles (2001), assim como os artigos no interior do livro. Há argumentos revisionistas em vários artigos de G. L. E. Owen, sobretudo no

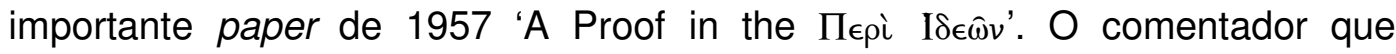
definitivamente estabelece o programa do revisionismo é Gilbert Ryle em seu artigo (em duas partes) sobre o Parmenides (1939) e em 'Letters and Syllables in Plato' (1960). Há uma análise da interpretação ryleana feita por Antonia Soulez em 'Le Travail de La Negation', in: AuBENQUE, P. (1991). Relevante para a tese revisionista é também o comentário de Owen em 'Notes on Ryle's Plato', em OWEN, (1986) ${ }^{18}$.

No que se refere à epistemologia platônica do Teeteto, um dos aspectos discutidos na literatura é o debate sobre o tipo de fluxo que Platão atribui ao mundo sensível. Aqui se vê que a oposição unitarismo-revisionismo é muito esquemática para refletir as linhas em conflito.

\subsection{A interpretação do mobilismo}

No presente trabalho apresento uma interpretação de alguns aspectos do mobilismo no Teeteto. Procuro explicitar em que sentido podemos entender a discussão do mobilismo e por que Platão considera importante conectar o mobilismo com Protágoras.

O que o mobilismo significa no Teeteto é uma questão menos complexa do que o sentido do mobilismo para Platão. As posições argumentadas na literatura são as seguintes. Suponhamos (1) que a argumentação da primeira parte do diálogo (sobretudo 151-6 e 181-3) seja uma análise do mundo

\footnotetext{
${ }^{18}$ As referências completas são: Fine, G., On ldeas. Oxford: OUP, 1993. Pradeau, JeanFrançols (Coord.), Platon: Les Formes Intelligibles, Paris: PUF, 2001; RYLE, G, 'Plato's Parmenides', Mind 48, n. 190 (abr. 1939), 129-51, "Plato's Parmenides', Mind 48, n. 191 (jul 1939), 302-325; "Letters and Syllables in Plato', Philosophical Review (1960), 431-51. SoulEz, A., 'Le Travail de La Negation', in: Aubenque, P. (dir.), Etudes Sur Le Sophiste de Platon. Paris:

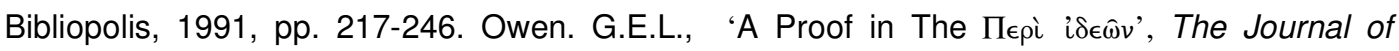
Hellenic Studies, Vol. 77, Part 1 (1957), pp. 103-111; 'Notes on Ryle's Plato', in: OwEN, G.E.L., Logic, Science and Dialectic: Collected Papers in Greek Philosophy (Ed. M. Nussbaum), Cornell University Press, 1986, 85-103.
} 
sensível a partir de premissas aceitas pelo próprio Platão. Se for verdadeira, essa hipótese salienta a tese de que a teoria da percepção desenvolvida nessa argumentação exibe os aspectos essenciais do heracliteanismo platônico. Essa posição é defendida por intérpretes como Cornford e Cherniss. ${ }^{19}$

De outro lado, supondo (2) que as premissas do argumento da primeira parte não são platônicas, mas representam teses atribuídas aos oponentes de uma perspectiva platônica de cognição, temos duas possibilidades:

(2.1) Toda a teoria da sensação desenvolvida em 151-156 é construída por Platão para mostrar a inconsistência da doutrina epistemológica dos oponentes, especialmente Protágoras. De acordo com essa análise, o sentido geral do argumento da primeira parte do Teeteto seria o seguinte: a teoria da percepção, incluídos aí os detalhes da chamada "doutrina decreta" em 151-6, é uma teoria constituída para dar corpo à definição "sensação é conhecimento", a fim de que percebamos quais são suas implicações. ${ }^{20}$

(2.2) Pode-se dizer também que Platão se liga a algumas partes da doutrina. Ele atacaria (a) o uso dos elementos da teoria para argüir uma tese epistemológica e (b) os heracliteanismo extremo (criticado em 181-3), mas manteria a doutrina secreta como descrição válida da sensação. (2.2) é a posição de Bostock (1988) e Owen (1957), (2.1) é a interpretação de Burnyeat (1990) e Fine (em vários artigos).

Vejamos alguns detalhes da disputa. No Teeteto 151-186 Platão vincula Protágoras a uma doutrina sobre o mobilismo sensível. No platonismo dos diálogos esse mobilismo característico do mundo da experiência é uma doutrina admitida. O problema para os intérpretes é explicar o significado da tese de que o mundo sensível está sob efeito do fluxo. Costuma-se confrontar

\footnotetext{
${ }^{19}$ Cf. Cornford, F.M., Plato's Theory of Knowledge. London: Routledge \& Kegan Paul, 1951 [1935]. ChERNISS, H. 'The Relation of the Timaeus to Plato's Later Dialogues', The American Journal of Philology, Vol. 78, No. 3. (1957), pp. 225-266.

${ }^{20}$ Essa interpretação é argumentada por Myles Burnyeat em 'Idealism and Greek Philosophy: what Descartes Saw and Berkeley Missed', The Philosophical Review, Vol. 91, No. 1. (Jan. 1982), pp. 3-40. Ver também sua Introdução à edição do Teeteto em BURNYEAT, 1990, na linha interpretativa que Burnyeat nomeia "leitor B".
} 
a tese (i) que o mobilismo é físico, é inerente às estruturas orgânicas do mundo natural, com a tese (ii), que sustenta que o mobilismo é metafórico, uma qualidade de "tokens" e "types" que não conseguem evitar o fato de serem em si mesmos $\mathrm{F}$ e não-F.

Essa disputa é típica da interpretação do mobilismo dos diálogos médios. Mas no Teeteto há uma perspectiva incomum. O mobilismo é uma premissa numa teoria epistemológica, algo que não vemos em nenhum outro lugar do corpus. Estrategicamente, a epistemologia mobilista é afirmada e depois criticada. Quando critica o mobilismo em 181-3, Sócrates argumenta que o mobilismo não pode ser um aspecto fundamental no conhecimento porque essa posição é auto-refutante. Contudo, Sócrates não tem a mesma postura em relação àquela doutrina da sensação em 151-6. O fato de essa doutrina ser abertamente mobilista e Sócrates não refutá-la, poderia sugerir que a doutrina é aceita pelo autor do Teeteto. De outro lado, é possível que a crítica de Platão em 181-3 não se destine a uma linha de heracliteanos, mas a toda forma de mobilismo que procura negar aspectos permanentes nos objetos, sobretudo nos objetos da sensação. Se a crítica tem esse escopo, Platão não tem motivos para reter, em sua visão da sensação, "partes" daquela doutrina de 151-6. Essa é a visão de Burnyeat.

A perspectiva unitária ligada a Cornford e Cherniss, de outro lado, defende que a crítica em 181-3 se dirige à forma extrema de mobilismo. Essa forma extrema propõe uma tese que Platão nunca teria defendido, pelo menos não há nada nos diálogos que indique um argumento sobre a coincidência dos processos sensíveis com a estrutura do que é cognoscível. Em 181-3, conforme aqueles intérpretes, teríamos uma crítica sobre a inconsistência da posição epistemológica de Protágoras e Heráclito. Isso é argumentado no texto sob a forma da versão extrema de mobilismo cognitivo. Platão estaria mostrando que, para poder ser cognitiva, a teoria precisa ser complementada por uma tese ontológica radical sobre a inexistência de estruturas fixas no mundo. Mas aí se mostraria em 181-3 que, embora o mobilismo seja verdadeiro do mundo sensível, ele não pode ser verdadeiro das descrições sobre o mundo sensível. 
Como se vê, a divergência reside no alcance da crítica ao mobilismo. Para alguns, como Owen (1957), a passagem 181-3 do Teeteto é uma crítica que impõe estabilidade (e conhecimento) ao mundo sensível, rechaçando o mobilismo. Para outros, como Cornford (1935), essa passagem é uma crítica que continua afirmando que o mobilismo é válido como tese sobre o mundo sensível.

$\mathrm{Na}$ seção seguinte procuro disciplinar alguns aspectos dessa disputa. Meu foco não será 181-3, mas a doutrina de 151-60.

\subsection{Platão e o mobilismo do Teeteto}

$\mathrm{Na}$ interpretação da primeira seção do Teeteto que apresento na seqüência, desenvolvo uma análise que retrabalha alguns elementos de uma das perspectivas sugeridas por Burnyeat em seu livro de 1990 (na linha que ele nomeia "leitor B"). O aspecto chave dessa interpretação é o destaque à conexão entre protagoreanismo e heracliteanismo. Essa conexão é interpretada como uma articulação dialética, criada por Platão, para dar consistência ao argumento. Burnyeat confronta essa linha com a hipótese, sustentada por Cornford e outros, que lê as teses do argumento como descrições platônicas da sensação. $O$ assunto, no entanto, é complexo, pois não se trata apenas de decidir entre duas linhas que, não por acaso, possuem iguais chances de serem verdadeiras. Burnyeat optou pela hipótese de que Platão está em todo o texto examinando teses adversárias, mas deixou claro que não encontrou argumentos válidos para descartar a hipótese alternativa, a idéia de que certos elementos de 151-6 são descrições platônicas do fenômeno da sensação. É por causa dessa indefinição que Burnyeat mantém na estrutura de seu livro de 1990 a contínua referência às duas linhas de interpretação. ${ }^{21}$

Talvez o problema de saber se partes ou o conjunto de 151-6 são mantidos por Platão - em alguma teoria da sensação válida - não possa ser

\footnotetext{
${ }^{21}$ Cf. Burnyeat, 1990, especialmente pp. 7-65.
} 
decidido em termos definitivos, pois se trata do tipo de posição que Platão não julgou necessário indicar no Teeteto.

Minha análise desse aspecto do diálogo se limita a defender o seguinte. Se as teses $\mathrm{P}$ (Protágoras) e $\mathrm{H}$ (Heráclito) representam posições complementares numa teoria da sensação que pretende ser uma teoria epistemológica - minha interpretação se encarrega do ônus dessa demonstração -, o fato de Platão desejar demonstrar a inconsistência do arranjo que, supostamente (cf. a hipótese) faria sentido na teoria, implica que seu objetivo é, exclusivamente, examinar a consistência desse arranjo na pretensão epistemológica. Nesse quadro, não há nada a ser dito sobre o que é o mundo sensível em si. Mas, de outro lado, de nada adianta o intérprete mostrar que a descrição da sensação na doutrina decreta (151-6) do Teeteto não é refutada e, eo ipso, é válida para Platão. De fato ela não é refutada em parte alguma do texto, mas não se pode esquecer que essa descrição é parte de um todo e esse todo é refutado por meio da demonstração da inconsistência de seu princípio básico: o mobilismo. Qual o ganho que o intérprete julga obter - para o conceito de sensação em Platão - ao tentar retificar os "destroços" da teoria? Penso que não é aí que reside o interesse dessa seção do Teeteto.

Se o exame do argumento a partir do problema de saber se Platão retém ou nega alguma parte de 151-6 é pouco útil, quais são, então, os temas relevantes? Os argumentos relevantes são os que contrastam a epistemologia de Protágoras com a perspectiva platônica de cognição. Minha análise, no tópico seguinte, procura mostrar que o argumento de Platão demonstra a incompatibilidade entre estas duas perspectivas, além de descrever a fissuras internas do protagoreanismo.

Pode parecer um tema óbvio demais para uma literatura que, atualmente, se ocupa das mais exasperantes disputas sobre o corpo do texto. Meu trabalho não nega o valor dos temas específicos do diálogo. Contudo, o que pretendi fazer é uma interpretação a partir do tema clássico do platonismo: a oposição entre razão e sensação. Penso que o Teeteto foi escrito por um Platão que quer explorar, filosoficamente, esse tema. Não podemos ignorar que, conforme certas datações (ver nota 02), o Teeteto é um diálogo "de 
velhice" 22 e, como tal, tende a ser uma ocasião para um relaxamento das doutrinas, filosóficas ou não. Nada disso, no entanto, precisa nos vincular a qualquer tese sobre o abandono do programa da República.

\subsection{O argumento mobilista de Protágoras}

Há um sentido em que os argumentos de 151-6 e as teses defendidas em 184-6 exprimem proposições incompatíveis. Na primeira seção nós temos a tese (i) que $x$ é $F$ para qualquer valor de $F$ que está na crença do sujeito e que foi resultado de sua percepção privada. Em 184-6 nós temos (ii) a tese de que a estrutura de pensamento " $x$ é $F$ " é uma estrutura apreendida pela razão por meio de entidades nomeadas "comuns" (коเvá, cf. 185a9-10, 185c5-186b9: ser, igualdade, identidade, diferença, número, não-ser, semelhança, dessemelhança, oposição). Como nenhum dos koiná é apreendido pela percepção, a afirmação em (ii) é, formalmente, negada em (i), e vice-versa. Em seu famoso artigo "The Place of the Timaeus in Plato's Dialogues", Owen considera que nestas duas passagens “...the Theaetetus states and explodes the thesis that $\gamma^{\prime} \in \in \in \sigma \iota s$ excludes oưoía. "23 Owen acredita que a parte que sugere a exclusão da ousia do vir-a-ser ( $\gamma^{\prime} \in \operatorname{v\in \sigma \iota s)}$ é 151-6 e a parte que nega essa exclusão é 184-6. Na primeira passagem temos as afirmações cruciais da conexão entre protagoreanismo e heracliteanismo, mas na segunda passagem o argumento examina o conceito de percepção. A conclusão deste último argumento é que não há nada no conceito de percepção que permita sustentar o que se sustentou em 151-6.

O objetivo de Owen é defender que a incompatibilidade entre $\gamma^{\prime} \in \operatorname{v} \in \sigma \iota s$ e oúoía não é o tipo de argumento que o autor do Teeteto adota na estrutura da primeira parte do diálogo. De acordo com Owen, uma evidência adicional de

\footnotetext{
${ }^{22}$ Roberto Bolzani Filho coloca o Teeteto nessa fase em sua excelente Introdução à tradução da República in: Prado, A. L. A. A., Platão A República. São Paulo: Martins Fontes, 2006, pp. VI-XLII, aqui $p$. XI.

${ }^{23}$ OwEN, G. E. L., 'The Place of the Timaeus in Plato's Dialogues', The Classical Quarterly, Vol. 3, No. 1/2 , 1953, 79-95, p. 85.
} 
que não se trata dessa estratégia é o fato que, em 185a-c e 186b, Platão atribui

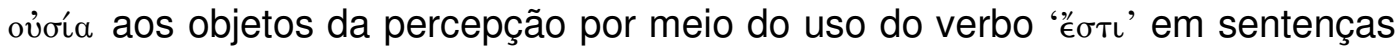
empíricas sobre objetos sensíveis como som e cor. Se Platão não se vale da tese, atribuída ao platonismo, que o mundo sensível é um mundo trespassado pelo vir-a-ser radical, com base em que argumento Platão julga que é possível refutar a tese de que a sensação é conhecimento? A resposta a essa pergunta depende de uma compreensão do termo "oủoía" no Teeteto. Se Owen está certo, Platão desenvolve no texto duas perspectivas de apreensão de ousia.

No Teeteto a expressão ousia aparece em várias situações, revelando que há um argumento baseado nesse conceito no diálogo. Minha interpretação propõe que, se compreendermos o conceito de ousia que Platão atribui a Protágoras, podemos entender o papel do mobilismo nessa primeira parte, assim como o sentido da crítica em 181-186.

\subsection{Ousia em Protágoras}

Em 160a-e Sócrates finaliza o desenvolvimento da teoria da percepção que vinha sendo desenvolvida. O objetivo dessa teoria foi amparar a tese de que a sensação é conhecimento. Em 160c7-8 Sócrates argumenta que

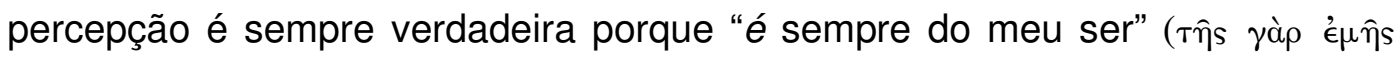

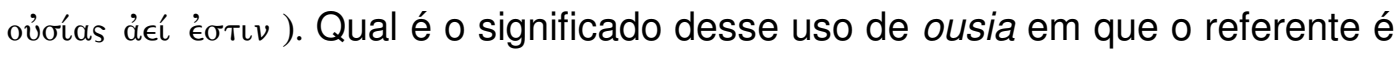
algo próprio ao sujeito? Para responder essa questão nós precisamos interpretar alguns movimentos cruciais de Sócrates na primeira parte do diálogo. Essa tarefa não é fácil porque a seção se tornou objeto de distintas e incompatíveis leituras. No que segue tento dar um sentido ao modo como Platão descreve os aspectos centrais da doutrina secreta e do protagoreanismo até 160.

No início da discussão, quando Sócrates conclui o primeiro argumento para a assimilação entre a definição (conhecimento é sensação) e a tese de Protágoras, ele diz: "percepção, portanto, é sempre do que é e é infalível,

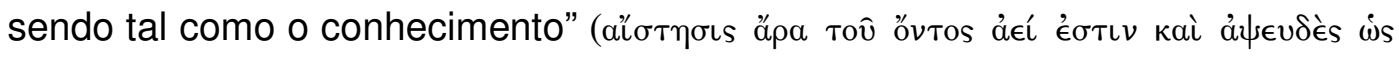




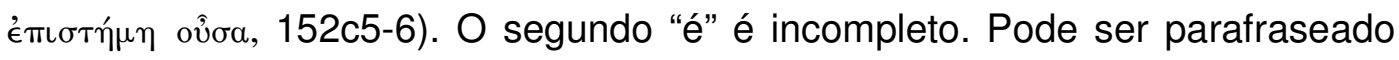
como "o modo como alguém percebe ser o caso". ${ }^{24}$

Há uma alternativa para a interpretação que apresentei na tradução de 152c5-6. Alguns comentadores sugerem que se leia a frase como a tese de

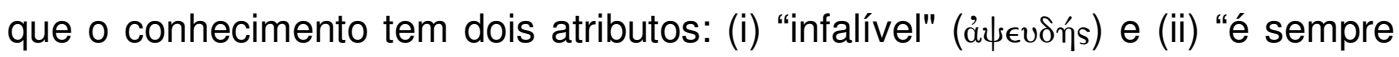

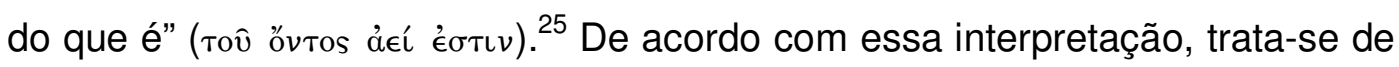
afirmar que, por ser conhecimento, a sensação apresenta os atributos mencionados acima. Essa interpretação só possui respaldo no material conhecido do conceito de conhecimento em Platão, geralmente relacionado com o aspecto estável das fórmulas que apresentam a $F^{\text {dade }}$ nos diálogos. $O$ segundo atributo é familiar nesses contextos e o primeiro, um tanto raro, também pode ser associado à noção de conhecimento em Platão.

Penso, todavia, que a estrutura gramatical da frase e o contexto no qual ela está inserida não favorece essa interpretação. A estrutura da frase indica uma interpretação conforme a análise de McDowell. Ele propõe que o sujeito da frase é a percepção e que os atributos são aspectos derivados do que está sendo expresso na argumentação anterior. Essa argumentação, nota McDowell, é a interpretação platônica da tese de Protágoras no trecho de 152b1-c7: "if someone perceives something as being $f$, then it is $f$ for him". ${ }^{26}$ No argumento dessa seção há uma identificação entre três elementos: aparência

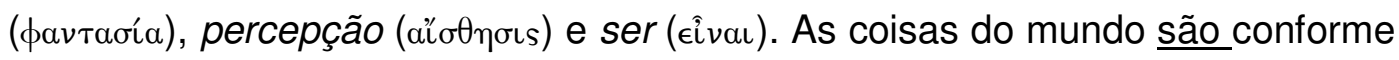
aparecem ao sujeito na percepção.

Além dessa evidência, vejo outra razão para defender a leitura de McDowell. Se Platão estivesse argumentando a infalibilidade do conhecimento e procurando verificar se a sensação protagoreana exibe esse atributo,

\footnotetext{
${ }^{24}$ CF. McDowelL, J., Plato: Theaetetus. OUP: 1973, p. 120.

${ }^{25}$ Cf. Cornford, (1935) p. 32; Gerson, L. P., Knowing Persons: a study in Plato. Oxford \& New York, OUP, 2003, 197ss.

${ }^{26}$ McDowell, Plato: Theaetetus. OUP: 1973, p. 120. Para uma análise mais detalhada ver

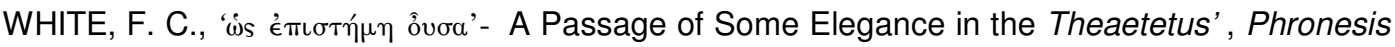
17, 1972, 219-226.
} 
deveríamos esperar alguma menção à infalibilidade do conhecimento em 1846, na passagem que finaliza o grande movimento de interpretação do pensamento de Protágoras, o qual tem início, precisamente, nessa primeira abordagem, em 151-2. Mas não há nada disso em todo o trecho de 151-186. Não encontrarmos nenhuma defesa da tese de que o conhecimento é infalível nessa primeira seção. Nesse caso, é mais provável que Sócrates não está argumentando a infalibilidade do conhecimento aqui, apesar de que um argumento sobre infalibilidade certamente está em jogo na segunda parte do Teeteto e, provavelmente, em outros diálogos. Além disso, a infalibilidade é uma marca do conhecimento em Platão. ${ }^{27}$

Penso que o ponto de Sócrates aqui é argumentar a infalibilidade da percepção. A infalibilidade da percepção é um atributo que esta possui porque sua estrutura é capaz de retratar o que aparece sob a perspectiva do que tem "ser". Vejo aqui o primeiro movimento do diálogo em direção a uma tese sobre a ontologia do mobilismo. O mais importante aspecto dessa ontologia é o fato de a palavra ousia receber nela um significado que não é o referente platônico para "ta onta", a configuração do mundo que o conhecimento das Formas permite apreender, mas um estado de coisas que a percepção apreende. É em Protágoras que essa perspectiva fará sentido, embora os alicerces da teoria ainda não estejam explicitados em 151-2, pois falta apresentar a complexa descrição do mecanismo da percepção, o que só ocorrerá a partir de 152c.

Não é apenas no Teeteto que Platão atribui a Protágoras uma apreensão da ousia de forma distinta da apreensão que costumamos atribuir ao platonismo. No Crátilo, em 385e5-386a4, Sócrates diz que, para Protágoras,

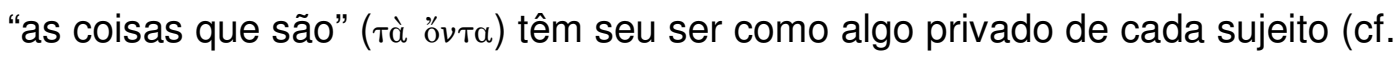

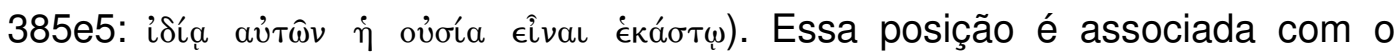

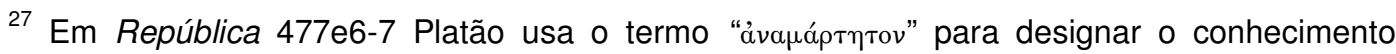
infalível. Gerson ( 2003, 197ss ) argumenta que não é o mesmo sentido que "å $\psi \epsilon u \delta$ ys" tem em 152c5-6, mas não considero seu argumento convincente. No Teeteto 200e4-5 Platão usa

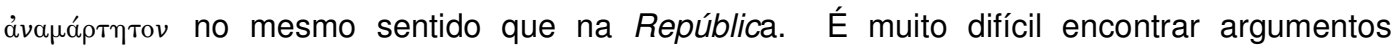
platônicos organizados por meio da distribuição de palavras.
} 
convencionalismo de Hermógenes.$^{28}$ Como no Teeteto, Sócrates descreve a doutrina do homem-medida no Crátilo como a tese de que, na aparência do que apreendemos do mundo, nós captamos o ser e o não-ser das coisas. Não se trata apenas de negar a oposição entre o ser e o não-ser por meio de uma ontologia generosa que aceita tudo sob o critério da percepção. Trata-se, antes, de algo mais extremo. Para vermos a exata medida desse conceito de ousia em Protágoras, precisamos avançar um pouco mais no entendimento da descrição que o autor do Teeteto faz da epistemologia protagoreana.

Interpretar Protágoras no Teeteto implica se envolver com as divergências sobre a interpretação do mobilismo. Como já mencionamos, existem perspectivas em conflito e há boas razões para se argumentar uma e outra. Não precisamos, no entanto, nos envolver com todos os aspectos do problema. Basta que tenhamos uma perspectiva unitária sobre o propósito do mobilismo na conexão com Protágoras, deixando aberta a questão do comprometimento platônico com os detalhes da teoria da sensação.

De acordo com Gail Fine, em seu artigo "Conflicting Appearances", a melhor pergunta que devemos fazer ao texto da primeira parte não é "o que Platão pensa?", mas "qual versão do heracliteanismo oferece o melhor suporte a Protágoras?" e "com qual versão do heracliteanismo Protágoras está

\footnotetext{
${ }^{28} \mathrm{~A}$ posição do texto do Crátilo em relação ao protagoreanismo (386a1-3) é essencialmente a mesma do Teeteto. Protágoras defende que cada um é medida das propriedades atribuídas aos seres existentes. A sensação é uma espécie de meio natural no qual "formamos" essas propriedades pelo contato entre os dados provenientes dos objetos e os órgãos sensíveis. Negando distinção entre "aparência" (phantasia) e sensação (aisthesis), Protágoras afirma a identidade entre ser e sentir (cf. hoîa gàr aisthánetai hékastos, toiauta hekásto(i) kaì kinduneúei eînai, 152c2-3). Ao colocar-se, no Crátilo, contra o relativismo protagoreano, Sócrates abre o caminho para a defesa do naturalismo lingüístico. Penso que esse naturalismo se apresenta na seqüência da rejeição de Protágoras por uma razão: o diálogo defende um naturalismo dos nomes regrado por uma technē e a tese de Protágoras é tida, por Platão, como a fórmula típica da negação de especialidades. Reside aí, portanto, o vínculo entre o relativismo protagoreano e convencionalismo.
} 
comprometido?". ${ }^{29}$ Fine percebe que a questão sobre a exata relação entre as teses da primeira parte, assim como as questões sobre a posição de Platão acerca da sensação ali desenvolvida, ao contrário do que alguns estiveram defendendo na literatura, não são as melhores questões do texto. McDowell, por exemplo, argumenta que o que Platão expressa sobre "ser" na Doutrina Secreta tem um paralelo com Timeu 27d5-28a4 e 37e5-38b5. De modo similar, Cornford descreve o heracliteanismo dessa seção como a tese platônica de que tudo o que é sensível está em perpétuo movimento. ${ }^{30}$ Esse paralelo só pode ser admitido com uma série de qualificações que não posso explicitar aqui. ${ }^{31}$

A melhor questão é perguntar por que o autor do Teeteto desenvolve a visão de Protágoras e Heráclito numa teoria única sobre a percepção? Com base na leitura de Fine, vou defender que Platão está desenvolvendo uma teoria infalibilista do conhecimento baseada nas aparências sensíveis. Seu objetivo com essa teoria é criar para Protágoras um mundo onde as proposições privadas (o discurso cognitivo) possam fazer sentido sem que tenham que se chocar com estruturas de objetos ou de crenças disponíveis.

Essa interpretação não se coaduna com a tese de que Platão constrói para Protágoras uma espécie de relativismo perceptual apenas parcialmente envolvido com o mobilismo heracliteano. Se quisermos descrever com acurácia a tese do Teeteto, temos que entender Protágoras a partir dos pontos extremos da doutrina mobilista. A doutrina desenvolvida por Platão para Protágoras é a tese de que as aparências coincidem com o modo com as coisas estão estruturadas no mundo. Para que a tese de que conhecimento é sensação faça

29 Cf. 'Conflicting Appearances', in FINE, G. "Plato on Knowledge and Forms". Oxford: OUP, 2003, 160-83, aqui p. 164.

${ }^{30}$ Cf. MCDowell, 1973, p. 124-8; CoRnFord, 1935, p. 36; Ver também Frede, M., 'Being and Becoming in Plato', OSAP Supplementary Volume 1988, 37-52.

${ }^{31}$ Os intérpretes sempre mencionam a relação entre o Teeteto e o Timeu no problema da descrição do mundo sensível. Creio que a melhor análise é a de DAY, J.M., 'The theory of perception in Plato's Theaetetus', OSAP 15, 1997, 51-80. Day argumenta que há aspectos incompatíveis irreconciliáveis sobre a descrição da sensação nos dois diálogos. 
sentido, Platão pensa que Protágoras precisa argumentar uma doutrina epistemológica baseada numa mudança genuína na estrutura dos objetos existentes. Isso está bem retratado na distinção entre um mero relativismo perceptual e o que Fine nomeia "infalibilismo". A primeira posição não requer nenhuma tese sobre a mudança inerente aos objetos, enquanto que a segunda precisa dessa tese.

Vejamos como o relativismo cognitivo, fundamentado num relativismo perceptual, é insuficiente para explicar o que Platão está propondo no Teeteto. A tese do relativismo perceptual afirma que as propriedades (o que é ser $x$, os aspectos das coisas, os estados de coisas) são relacionais. Essa tese pode ser descrita do seguinte modo. Nossos órgãos sensíveis são estimulados por aspectos dos objetos, um fenômeno que produz em nós uma aparência privada. É esta aparência que dá nascimento à crença no conteúdo do que estamos experienciando naquele momento. O conteúdo dessa aparência pode ser descrito como "é deste ou daquele modo para mim". Por meio da identificação entre ser, aparência e percepção, (cf. o argumento de 151-2) obtemos o relativismo que a doutrina protagoreana requer. Platão está, aqui, atribuindo a Protágoras uma tese relativista baseado no princípio de que tudo o que é experienciado pelo sujeito deve ser avaliado conforme o critério "é verdadeiro para mim", uma regra que passa a ser o critério de verdade.

Platão está, de fato, atribuindo essa tese a Protágoras, mas se supormos que esse aspecto da verdade relativa está no coração da doutrina de Protágoras e constitui, desse modo, a articulação nodal de toda a doutrina epistemológica que Platão está atribuindo ao sofista, devemos concluir que a conexão com o heracliteanismo é ociosa. A epistemologia baseada no relativismo perceptual não precisa de Heráclito. O primeiro problema, portanto, é o problema da ociosidade do heracliteanismo no argumento.

É fácil ver que o relativismo da verdade é um componente crucial, mas não esgota a doutrina. Quando ataca Protágoras na auto-refutação (168c171c), é esse tipo de relativismo da verdade que interessa a Platão. O mobilismo só será atacado depois. 
A crítica de Platão ao relativismo da verdade em 168c-171c tem a seguinte estrutura. A tese protagoreana oferece dificuldades quando o conteúdo da tese é avaliado unicamente como tese da relatividade da verdade. O procedimento de "avaliar" o que a tese " $p$ para $x$ " significa já é um passo auto-refutativo ou, no melhor dos casos, um procedimento que 0 protagoreanismo precisa assumir que não é permitido. Se Protágoras defender que tudo é relativo, incluindo, sobretudo, o conceito de verdade, a tese protagoreana não pode ser considerada verdadeira, digamos, por "duas pessoas", pois isso mostraria que há pelo menos um estado de coisas nãorelativo, a tese protagoreana "sendo" verdadeira para duas pessoas. Isso mostra que não podemos afirmar que a fórmula "p para x" é a fórmula correta que retrata a estrutura cognitiva no universo protagoreano, pois a asserção de que a formula "p para $x$ " retrata a condição cognitiva válida no mundo protagoreano é incompatível com o que "p para x" significa. Será que a insistência nos qualificativos (é verdade para) resolve o problema? Essas questões estão no coração da chamada auto-refutação protagoreana em 168c171c. O autor do Teeteto procura refutar a fórmula por meio da identificação de uma inconsistência entre o que a tese significa e o que se pode dizer ou pensar "de verdadeiro" sobre ela. Como meu objetivo é avaliar o papel do mobilismo no argumento, os problemas da auto-refutação não serão abordados aqui. $^{32}$

O argumento acima é completo na medida em que refuta o aspecto relativista da tese protagoreana enquanto tal, mas ele não é suficiente para desmontar todo o edifício da definição protagoreana de conhecimento. Se o conceito de verdade relativa fosse suficiente nessa definição, o mobilismo

\footnotetext{
${ }^{32} \mathrm{O}$ argumento da auto-refutação tem recebido uma atenção crescente na literatura. Algumas análises relevantes estão em LEE, MI-KYOUNG, Epistemology After Protagoras: responses to relativism in Plato, Aristotle, and Democritus. Oxford: OUP, 2005, pp. 46-72; BURNYEAT, M., 'Protagoras and Self-refutation in Later Greek Philosophy' Philosophical Review 85 (1976), 4469; Burnyeat, M., 'Protagoras and Self-refutation in Plato's Theaetetus', Philosophical Review 85, 172-95; FINE, G., 'Plato's Refutation of Protagoras in the Theaetetus', Apeiron 31/3 (1998), 201-34;. Chappell, T., Reading Platos's Theaetetus. Indianapolis/Cambridge: Hackett, 2005, pp. 108-117.
} 
inerente aos objetos deixaria de ser necessário. ${ }^{33}$ Neste caso a doutrina secreta, elaborada a partir de 152c, sobretudo o aspecto da sugestão de reforma da linguagem que se vale do verbo einai, tornar-se-ia supérflua.

As dificuldades encontradas para explicar o que Platão quer com a associação entre sensação, protagoreanismo e mobilismo constituíram algumas alternativas de interpretação. Alguns propuseram que o mobilismo da doutrina secreta é um aspecto das propriedades e não atinge a estrutura intrínseca dos objetos. Os objetos sensíveis manteriam suas características. Somente no encontro entre objeto e sujeito teríamos uma mudança nas propriedades dos objetos, pois o que o sujeito percebe é privado. Essa interpretação é desenvolvida - como uma tese platônica - por Crombie, mas, no final, ele não a endossa. ${ }^{34}$

Prefiro pensar que os objetos da doutrina decreta são objetos do mundo protagoreano e nesse mundo eles não são entidades discretas. Um aspecto dessa leitura já foi sugerido, mas não argumentado, por Nakhnikian: "the

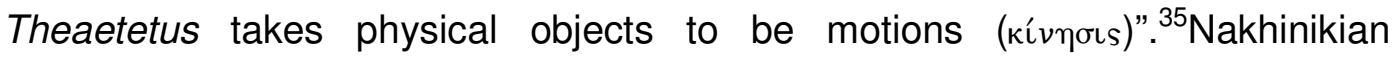
entende que a doutrina da sensação em 152-6 é platônica e acredita que o criticismo em 181-3 alcança somente o heracliteanismo extremo, i.e., o heracliteanismo sobre valores e opiniões. Há uma alternativa ao heracliteanismo em Platão, no entanto, que não assume o mobilismo na natureza dos objetos. Essa alternativa é defendida por Owen, Nehamas, Irwin e Fine, que argumentam um tipo de fluxo nomeado "compresence of opposites". $O$ aspecto central dessa espécie de fluxo é a co-presença de aspectos contrários em types e em tokens. A seção do vento é um exemplo desse tipo de fluxo. ${ }^{36} \mathrm{O}$ vento em si mesmo não é frio ou quente. O vento (universal)

\footnotetext{
${ }^{33}$ Bostock parece perseguir o mesmo ponto em 1988, 47ss.

${ }^{34}$ Crombie, An Examination of Plato's Doctrines, vol. II. New York, Routledge \& Kegan Paul, 1963, pp. 12ss

${ }^{35}$ NAKHINIKIAN, G., 'Plato's Theory of Sensation' , Review of Metaphysics, 9 (1955/1956) 129148, p. 134.

${ }^{36}$ A interpretação é defendida por Irwin em IRWIN, T. 'Plato's Heracliteanism', The Philosophical Quarterly, Vol. 27, No. 106 (1977), 1-13, especialmente p. 02. Em relação a esse problema, há
} 
figura no argumento como um evento capaz de ser F e não-F. Quando é associado a Protágoras, o exemplo do vento ajuda a corroborar a identificação entre aparência e conhecimento, mas o mundo protagoreano só será completamente descrito na Doutrina Secreta a partir de 152c, o que implica que o exemplo do vento ainda é um exemplo neutro entre, de um lado, os argumentos platônicos da República sobre a instabilidade do mundo sensível e, de outro, o mundo mobilista da epistemologia protagoreana.

\subsection{O programa da Doutrina Secreta}

Minha razão para defender que os objetos da doutrina secreta são os objetos do mundo protagoreano se ampara no fato que uma interpretação dessa problemática deve dar um sentido plausível à conexão entre Protágoras e o mobilismo sem, porém, sobrecarregar Platão com uma tese improvável acerca do mobilismo do mundo sensível. ${ }^{37}$ Penso que o programa da doutrina secreta oferece elementos suficientes para caracterizar o universo mobilista da epistemologia protagoreana.

O Heracliteanismo providencia para o protagoreanismo um mundo sem objetos estáveis. O programa da Doutrina Secreta tem um princípio geral que sustenta essa configuração do mundo: "nada é algo uno em si mesmo" (êv $\mu \grave{\epsilon} v$

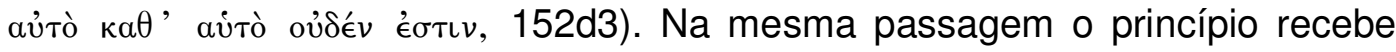
algumas qualificações restritivas. Não se pode falar como se existisse um

uma passagem no Teeteto em 153d-154b que já fez muita gente esquentar a cabeça. Em "Conflicting Appearances" Fine contribui bastante para esclarecer essa difícil seção do diálogo (cf. FINE, 2003, p. 160-83). Tenho a impressão que Fine oferece uma boa resposta aos problemas descritos por Bostock em seu comentário da seção dos "dados". Ver Bostock, 1988, 45-83, especialmente p. 83.

${ }^{37}$ Isso não significa que não se possa encontrar no Teeteto um argumento mobilista sobre o mundo sensível que satisfaça as condições impostas por Platão. K. Sayre apresenta boas razões para avaliarmos a hipótese de que a doutrina da sensação do Teeteto retrata uma das versões do conceito platônico de mundo-sensível. Cf. SAYRE, K., Plato's Late Ontology: a riddle resolved, with a new introduction. Parmenides Publishing, 2005, pp. 206-218. 
"item-sujeito" $(\tau \iota)$ ou uma "qualidade-predicado" (ómoเovov̂v $\tau \iota) .{ }^{38}$ McDowell nota que essas restrições podem ser interpretadas conforme uma distinção entre duas espécies de asserções que alguém pode fazer sobre um tema ou sobre um objeto. ${ }^{39}$ Ele explica a diferença da seguinte forma: (a) dizer de um objeto que ele é um item especificado é responder à questão: "o que é?". A segunda opção seria: (b) dizer de um objeto que ele é qualificado de certo modo é dizer "com o que ele se parece". Poderíamos argumentar qual das opções representa o ser de um objeto em Platão, mas o aspecto principal aqui (não necessariamente o exclusivo) não é o que um objeto é ou o que um objeto qualificado de certo modo significa para Platão, mas o que significa para Protágoras um objeto ser algo e ter uma qualidade, se isso é explicado sem referência a alguma noção objetiva. Conforme minha leitura, nós temos nesse argumento o mais importante movimento de um novo mundo epistemológico construído no Teeteto: o mundo protagoreano. Os limites desse mundo são o espaço entre o percipiente e o objeto percebido. É nesse limite que um "itemsujeito" e uma "qualidade-predicado" encontrarão um modo de expressão.

Esse mundo desprovido de itens discretos e propriedades estáveis será criticado em 181-3. Platão argumentará em 181-3 contra a mudança genuína, i.e., o que estive chamando de mobilismo extremo. A maior parte dos intérpretes está de acordo sobre isso, inclusive Owen. Mas o que defendo é que esse argumento também atinge a Doutrina secreta, na medida em que essa doutrina dá suporte a Protágoras. Estou assumindo que o interesse de Platão nessa doutrina é o mundo epistemológico que ela configura para que as proposições, que no universo protagoreano expressam conteúdos cognitivos, sejam, de fato, fundamentadas na verdade da tese segundo a qual o homem é a medida de todas as coisas. Platão pensa que esse mundo precisa ser caracterizado sem objetos discretos e sem noções objetivas.

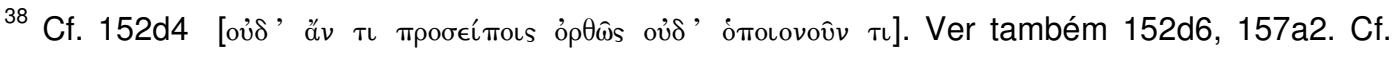
SEDLEY, 2004, p. 39.

${ }^{39}$ MCDOWELL, 1973, p. 122. 
Estou assumindo também que "objetos discretos" é uma noção geral que inclui propriedades e matéria. Não penso, todavia, que seja possível sustentar que no universo protagoreano não há "matéria". Mas também não é possível dizer que existem "substâncias", ao modo aristotélico da Metafísica, que povoam o mundo. Os objetos no mundo protagoreano não estão lá para serem responsáveis pela sensação, tal como, numa teoria causal da sensação, poderíamos argumentar. ${ }^{40}$ Mesmo que o status de uma matéria sem propriedades fixas, no protagoreanismo, seja um tema difícil de explicitar, o Teeteto permite afirmar que os objetos "são movimentos", sem esclarecer o que sobra de estável numa ontologia dos objetos em Protágoras.

Minha análise mostra que 0 criticismo de Protágoras e Heráclito tem implicações mútuas. A conjunção de teses configurou um universo sem propriedades estáveis e sem sujeitos fixos. No que segue quero explorar o aspecto privativo da consciência individual no mundo protagoreano.

\subsection{Privacidade, Estabilidade e Alma.}

David Sedley argumenta que o protagoreanismo construído por Platão no Teeteto apresenta uma noção de "incorrigibility of our sense-data limited to the incorrigibility of sense-perception" ${ }^{\prime 4}$. Sedley, no entanto, manifesta algumas dúvidas sobre a extensão dessa noção. Como Protágoras crê que o conceito de privacidade mental possa conviver com o conceito de um mundo externo? $\mathrm{O}$ problema pode ser caracterizado da seguinte maneira. A Doutrina Secreta, assumida como descrição do mundo protagoreano, se desenvolve como uma "interação" entre órgãos sensíveis e aspectos provenientes dos objetos. É uma relação entre o que é interno e o que é externo. A passagem seguinte mostra isso:

\footnotetext{
${ }^{40}$ Cf. H. P. Grice \& Alan R. White, 'The Causal Theory of Perception', Proceedings of the Aristotelian Society, Supp. Vol. 35 (1961), pp. 121-168.

${ }^{41}$ SedLEY, 2004, p. 42.
} 
Sigamos o que dissemos há pouco e estabeleçamos que nada é algo uno em si mesmo. Nessa linha, entenderemos que o preto, o branco e qualquer outra cor serão geradas da colisão dos olhos com o movimento apropriado. $O$ que dizemos ser determinada cor não será, nem o objeto que colide, nem o que sofre a colisão, mas algo peculiar que se forma entre eles. ${ }^{42}$

Nessa passagem são rejeitadas duas hipóteses para o status ontológico da cor: não é algo que se identifica com o objeto e nem é algo que se identifica com o percipiente, mas é algo intermediário. Não temos nenhuma explicação mais precisa sobre a natureza disso que se forma entre o olho e o objeto. $O$ que se afirma em todo o argumento sobre Protágoras é que o conhecimento segue essa lógica. O que é cognoscível não é uma propriedade dos objetos e nem é uma propriedade da alma ou dos órgãos sensíveis do sujeito. É algo intermediário. É importantíssimo notar aí que o exemplo da cor não é uma analogia para explicar o relativismo perceptual, mas uma instância do princípio mobilista que, no trecho acima, é claramente universal: "nada é algo uno em si mesmo".

Agora, se Platão estivesse propondo para Protágoras uma tese sobre a privacidade subjetiva do conhecimento, esse processo teria que se dar no âmbito mental. De fato, algumas passagens depois, em 156ss, Sócrates menciona fenômenos associados a "delusions" (alucinações), um conceito conectado à noção de privacidade mental (mental privacy). Parece, portanto, que a fronteira entre o mental e o não-mental no exame de Protágoras não é muito clara.

A interpretação correta, como observa Sedley, é que o conceito de privacidade mental é insuficiente para explicar o protagoreanismo. O tipo de incorrigibilidade que Platão está argumentando para Protágoras não se explica pela noção de algo privativo que se constitui na mente do sujeito, uma espécie

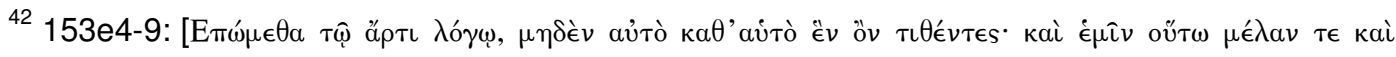

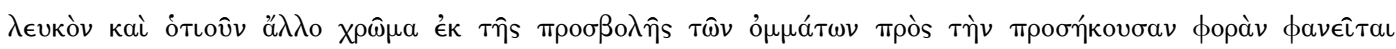

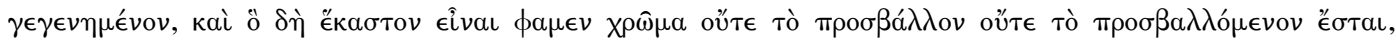

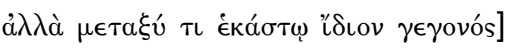


de consciência unificadora de todas as experiências sensíveis. $O$ protagoreanismo não é uma epistemologia baseada na tese que, se não há qualquer item objetivo no mundo, a única fonte de cognição seria a própria consciência individual.

Na hipótese de essa "inspeção privada" se realizar exclusivamente em minha mente e coincidir com a noção de verdade proposta pela epistemologia protagoreana, por que não posso sustentar que Protágoras está, de fato, propondo uma epistemologia subjetivista nesse sentido? O problema é que uma epistemologia subjetivista no sentido de uma privacidade cognitiva no âmbito mental é compatível com a estabilidade dos objetos e, inclusive, trata-se de um aspecto de nossa vida comum, independentemente de aceitarmos a epistemologia protagoreana ou a platônica. Nós provavelmente não seríamos os seres humanos que somos se não pudéssemos dispor desse conceito de privacidade mental. É improvável que Platão não concorde com isso.

Vejamos por que o argumento do protagoreanismo não coincide com 0 conceito de privacidade mental. Em 157e-158a Sócrates acrescenta mais exemplos para explorar as conseqüências da tese protagoreana. Do ponto de vista do senso comum, esses exemplos mostram que "existem falsas

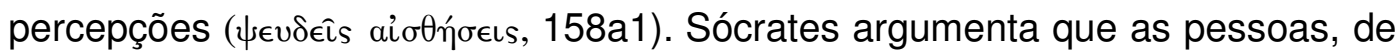
um modo geral, consideram que casos de doenças, loucura ou outras formas de perturbação psíquica, assim como falsas opiniões sobre o "bem" e o "belo (cf. 157d), revelam a possibilidade de julgamentos equivocados sobre o que existe lá fora, no mundo. Assim, temos que confrontar esse fato, trivial, com a negação dessa possibilidade pela teoria protagoreana. Sócrates se apóia no fato de que se as pessoas acreditam que há falsas percepções, pode-se argumentar que há um ponto de vista verdadeiro e um ponto de vista falso sobre as coisas. Protágoras precisa refutar isso. Para explicar essa inconsistência entre o que o senso comum percebe e 0 argumento de Protágoras, Sócrates desenvolve um argumento sobre a condição do sujeito e do objeto na percepção (158e-c). Nessa passagem Sócrates argumenta que o sujeito não mantém a mesma condição durante a percepção. A cada percepção há uma mudança no estado mental do sujeito, mudança esta que 
acompanha o mobilismo inerente aos objetos. No final desse argumento ele conclui com a seguinte afirmação:

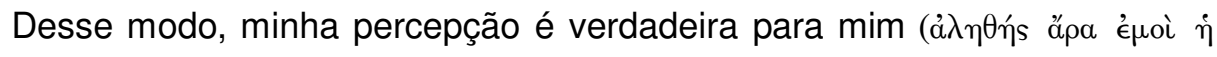

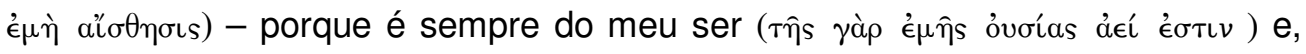
como Protágoras disse, cabe a mim decidir, das coisas que são, que elas são, e das coisas que não são, que elas não são. (160a7-9)

O vínculo com a frase de 152c não poderia ser mais claro: "percepção, portanto, é sempre do que é e é infalível, sendo tal como o conhecimento"

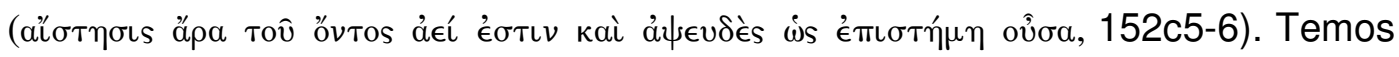
aqui uma noção de privacidade eminentemente protagoreana para a teoria da percepção. O conceito de ousia, mencionado aqui, deixa de ser uma nominalização para propriedades ou estados de coisas existentes objetivamente para se tornar, na epistemologia de Protágoras, uma referência à privacidade da cognição. Mas não é uma subjetividade de tipo cartesiana. $O$ mundo protagororeano admite uma noção de ousia, porém lhe dá uma forma de apreensão distinta da platônica. O conceito de ousia em Protágoras expressa a perspectiva cognitiva de um sujeito que nunca erra porque tanto ele quanto os objetos estão sob efeito do mobilismo. Não se trata da tese de que a estrutura mental privada do sujeito garante o acesso à verdade, mas do fato de que nem no sujeito e nem no mundo há estabilidade. O conceito de infalibilidade da percepção é, portanto, um conceito de incorrigibilidade total e irrestrita amparado em certa configuração mobilista do mundo.

Essa conclusão, no entanto, é o estágio final de um longo argumento. $\mathrm{O}$ princípio do argumento está em 153e4-5: "nada é algo uno em si mesmo"

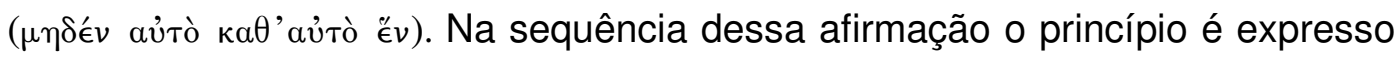

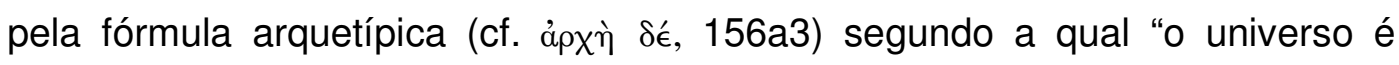

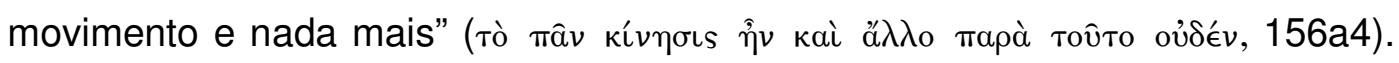
Em teorias complexas (no sentido cartesiano de compostas) é comum identificarmos princípios e aspectos derivados. Os princípios possuem a função de dar suporte à teoria como um todo. Isoladamente eles não indicam muita coisa, mas no arranjo proposto no texto eles dão coerência à teoria. No tópico 
seguinte explico como leio a relação entre os princípios da teoria e as conseqüências derivadas.

\subsection{A teoria de Protágoras e os objetos estáveis}

Toda a análise que o Teeteto faz do de Protágoras tem no mobilismo o princípio básico. De outro lado, a teoria apresenta certas afirmações que qualificam o princípio. Uma delas é a exclusão do verbo "einai". Em 157a-b8 Sócrates argumenta que palavras como "algo", "alguém", "isto", "aquele" e "meu" (uma lista que considero representativa, não exaustiva) precisam ser excluídas da epistemologia protagoreana. Essa qualificação é uma clara afirmação de que as coisas não "persist through time", como afirma McDowell. ${ }^{43}$ De acordo com McDowell isso significa uma negação da referência no mundo, pois palavras como "isto" ou "aquilo" sempre "pegam" (pick-up) entidades com alguma estabilidade (cf. Crátilo 439d8-11, Timeu 49d4-e4). McDowell aproxima a exclusão do verbo "ser" com a impossibilidade de referência por meio da linguagem, i.e., a impossibilidade de ser referir a "algo". O que sobra, no entanto, para a percepção, nota McDowell, não é claro. Sem nada que siga os critérios de um "isto", "algo" ou "aquilo", não há absolutamente nenhuma coisa individual e nós não podemos descrever nada que esteja acontecendo na percepção.

Segundo McDowell, para descrevermos algo na percepção precisamos de um conceito que esteve, propositadamente, ausente da discussão até aqui: a mente. A ausência do conceito não significa que Platão esteja sugerindo que a "medida" protagoreana é um critério usado por um "homem sem mente". O que Platão quer mostrar é que o conceito de mente ou alma, fundamental na percepção, não teve nenhum papel ativo na teoria até aqui.

É fácil ver a razão disso. Se aceitarmos qualquer agência da alma, na linha do que é argumentado em 184b8-d6, precisamos admitir alguma coisa estável, pois "mente ou alma" significa, no Teeteto, "pensar sobre" ou "obter

${ }^{43}$ Cf. McDowell, 1973, 141. 
algo por meio de". Pretendo esclarecer isso mais adiante. Nesse momento, é suficiente dizer que a alma surge no argumento do Teeteto quando Sócrates começa a elaborar a tese de que a sensação é um jogo cego de fluxos e que, para ser efetivamente um processo sensório, precisa admitir um agenciamento externo ao fluxo. Esse agenciamento será atribuído, notadamente, à alma.

Há outro aspecto relevante que decorre da introdução do conceito de alma. Se admitirmos que a alma tem algum papel na sensação, temos que admitir o conceito de algo que "penetra" na alma. Trata-se do conceito de um objeto externo que "causa" a percepção por meio dos órgãos. Os movimentos dos órgãos adentram a alma e atingem a consciência do sujeito. Mas se algo causa minha percepção, sou obrigado a admitir que existe uma entidade que possui "persistência" no campo exterior à percepção. É bastante claro que Protágoras não pode admitir isso sem admitir também o acolhimento, em sua epistemologia, do aspecto estável que o verbo ser descreve e das entidades fixas que as palavras costumam exprimir.

O status dos objetos no protagoreanismo, porém, continua sendo um problema na interpretação. Crombie ${ }^{44}$ nota que a concepção de "coisas" (things) na soutrina secreta, embora seja consistente com uma teoria causal da percepção, é inconsistente com o texto. Ele discute a opção "metafórica" de interpretação, uma linha que interpreta toda a descrição de 151-6 como retrato analógico do que ocorre na sensação. Crombie abandona essa interpretação porque considera que a crítica de 181-3 assume que 151-6 é uma doutrina descritiva e não metafórica, o que implica que o argumento de 181-3 atinge 151-6.

A posição final de Crombie na análise é um tanto evasiva: ele defende que Platão deseja, na Doutrina Secreta, obter uma teoria causal da percepção, mas Platão não está bem esclarecido sobre como fazê-lo, especialmente porque não decidiu o que é uma coisa é o que é um sense-datum. Todas as dificuldades discutidas por Crombie, num dos mais lúcidos tratamentos do tema na literatura, poderiam ser minimizadas se Crombie aceitasse que são

${ }^{44}$ Crombie, 1963, pp. 18-19. 
problemas para Protágoras e não para Platão. Protágoras não pode aceitar uma teoria causal, portanto, ele precisa explicar a natureza dos objetos que são definidos como "movimento".

Gostaria de finalizar a análise da epistemologia protagoreana retomando o ponto da infalibilidade. Platão descreve essa epistemologia como afirmação das teses professadas no núcleo duro da doutrina, em 151-6. A doutrina não é uma doutrina da sensação compatível com processos cognitivos que se dão num meio "público", i.e., num meio onde há uma esfera pública de percepção de objetos. Seria possível, para Platão, argumentar uma doutrina da percepção como fenômeno privado $\mathrm{e}$, sem nenhum problema de inconsistência, argumentar que a existência de um sense-datum, que não é perceptível a mais ninguém, não implica que todos os aspectos da sensação sejam privados nesse sentido. Russell desenvolve essa compatibilidade de um modo que parece retratar o conceito de sensação tal como Platão o descreveria:

"The core of the sort of occurrence which is usually called a perception of an external object is an event having two characteristics: (I) It is causally connected with a train of previous events having, so to speak, a centre in a certain region of physical space; (2) it can be "known" by a "person", i.e. it has relations of the kind implied when one says that it is "experienced". These two characteristics are not necessarily connected. Events having the first characteristic constitute the physical world; events having the second constitute the mental world. Thus what constitutes the occurrence called an external perception is both mental and physical; but such occurrences do not constitute the whole of the physical world, nor yet the whole of the mental world" ${ }^{\text {" }}$

No mesmo artigo Russell cita o exemplo do triângulo e do ponto negro, dois objetos facilmente identificados pela percepção. Quando digo "eu vejo um ponto preto" ou "eu vejo um triângulo", estou retratando experiências distintas

\footnotetext{
${ }^{45}$ RusselL, B. 'Perception', Journal of Philosophical Studies, Vol. 1, No. 1 (Jan., 1926), pp. 7886 , aqui p. 86.
} 
de experiência "há um ponto preto" e "há um triângulo". Nesta última frase, de acordo com Russell, a ocorrência da percepção, como tal, não explica o fato de eu estar percebendo que existe um triângulo. Na frase "há um triângulo" o que se refere ao verbo "há" (there is) pressupõe um espaço e o que se refere à palavra "triângulo" pressupõe um objeto público cuja existência é atestada por nossa memória. Essa análise é a negação do universo protagoreano do Teeteto. Embora o ataque russelliano ao conceito de "existência" em Platão seja bem conhecido, o ponto de Russell neste artigo de 1926, no JPS, não menciona o conflito com Platão, apesar de Russell conhecer bem a tese de 184-6. ${ }^{46} \mathrm{O}$ que temos aqui é uma afirmação sobre o equívoco de uma teoria da percepção que não descreve a sensação como um evento complexo no qual o que é físico e o que é mental se cruzam para formar a sensação. Esse cruzamento não interfere, todavia, na distinção formal entre o que é físico e o que é mental. Assim, pode-se defender que o que é estritamente privado na

${ }^{46}$ Como atesta o seguinte trecho do artigo: "Cognition is of various sorts. Take, as important kinds, perception, memory, conception, and beliefs involving concepts. Perception is the ordinary awareness of sensible objects: seeing a table, hearing a piano, and so on. Memory is awareness of a past occurrence, when this awareness is direct, not inferred or derived from testimony. Conception is more difficult to characterize. One may say, as a way of pointing out what is intended, that we "conceive" whenever we understand the meaning of an abstract word, or think of that which is in fact the meaning of the word. If you see a white patch of snow, or recall it by means of images, you do not have a concept; but if you think about whiteness, you have a concept. Similarly if, after seeing a number of coins, you think about roundness as a common characteristic of all of them, you have a concept. The object of your thought, in such a case, is a universal or a Platonic idea. Every sentence must contain at least one word expressing a concept, and therefore every belief that can be expressed in words contains concepts” (Russell, B, 'Perception', Journal of Philosophical Studies 1, vol. 1 (jan 1926), p.7886, aqui p. 79. ). O que Russell chama 'the object of thought', em casos como redondez, tem alguma similaridade com o argumento de Platão no Teeteto 184-6. A noção russelliana de "common characteristic", no exemplo da moeda é, por exemplo, uma reminiscência da noção platônica de koiná. Digo "reminiscência" porque em History of Western Philosophy (London: George Allen \& Unwin LTD, 1957, p. 174ff.) Russell comenta o Teeteto 184-6 e aceita parte (no caso dos números) da visão platônica sobre os koiná. Ele critica, obviamente, a redução que o argumento propõe da capacidade da percepção no conhecimento. 
percepção é a percepção de aspectos dos objetos que nenhum outro sujeito pode perceber, mas essa percepção precisa da contraparte física, fornecida por um mundo composto de objetos estáveis. É necessário que exista lá fora um mundo mais ou menos estruturado que "cause" a percepção.

Sabemos que Russell defendeu que o conhecimento desse mundo exterior é tarefa da física. Platão, no Teeteto, descreve esse conhecimento como um deslocamento do ponto de vista protagoreano em direção á compreensão do papel da alma na percepção, o qual estabelece um ponto de litígio com Russell. Para Platão a distinção entre percepção e razão é uma distinção entre eventos que são exclusivamente físicos e eventos que são exclusivamente mentais, tanto no interior da percepção, com forte predominância da razão, como na reflexão propriamente dita. Já Russell prefere dizer que a percepção é uma experiência onde o mental e o físico não podem ser distinguidos.

Para Protágoras, no entanto, nem a descrição russelliana da complementaridade das esferas física e mental, nem a descrição platônica da necessidade de um agenciamento da alma na percepção, retratam aspectos necessários ao conhecimento. O que é necessário é que a aparência seja efetivamente uma apreensão infalível do mundo. Se algo nesse mundo for público, qualquer sujeito pode perceber. Por isso, para Platão, a simples relatividade das crenças dos sujeitos não garante aquilo que o protagoreanismo diz que é necessário: a identidade entre aparência, percepção e ser.

Em síntese, a análise que Platão faz da epistemologia protagoreana mostra que há uma plausibilidade na tese de que percepção é conhecimento se, e somente se, definirmos o conhecimento de um modo que exclua o significado ordinário da palavra ousia. Para esse movimento de interpretação fazer sentido, porém, é necessário garantir duas condições: (i) a verdade precisa ser definida como a consciência perceptiva da pessoa numa dada situação; (ii) não podem existir objetos estáveis. Os objetos são "movimento".

O conceito de ousia em Protágoras tem as características identificadas por M. Frede em sua análise do Teeteto: 
"It seems to me that in the context of the discussion in the Theaetetus 'to become' might means something like this: 'to temporarily take on, or display, or be made to display the outward character or marks of an $\mathrm{F}$, to come to give or to give the appearance of an F". In this ways the contrast between being and becoming would be the contrast between what is a real $F$ and what just takes on or displays the superficial marks of an $\mathrm{F}$, without being one." ${ }^{47}$

Por que, em vez de dizer "há um F que é de tal e tal tipo" ou "algo é F" ou "nós somos F", devo dizer que "há um F que é de tal e tal tipo somente no meu campo perceptivo"? Por que sem essa doutrina não há infalibilidade da percepção no mundo protagoreano. A idéia de que "há um F" que apenas exibe temporariamente o caráter de F é inusitada e anti-platônica. Frede defende aqui que não é uma menção à tese de que instâncias e universais podem ser $F$ e ser não-F. O argumento de Platão não segue essa linha, familiar ao Fédon e à República. Pode-se dizer que o argumento segue uma linha "diferente". A epistemologia protagoreana tem as características de uma epistemologia conseqüente. Ela tem uma noção de ousia apreendida pela sensação.

\section{CAPÍTULO III}

\section{RAZÃO E SENSAÇÃO EM 184-6}

\subsection{O argumento de 184-6}

Em 184-6 ${ }^{48}$ Platão tem dois propósitos. Primeiro, ele argumenta que há uma relação entre o corpo e a percepção. Depois, ele argumenta que, do ponto

\footnotetext{
${ }^{47}$ FREDE, 1988, p. 43.
}

48 A passagem tem importantes contribuições em HolLAND, A. J. 'An Argument in Plato's Theaetetus: 184-6', The Philosophical Quarterly, Vol. 23, No. 91. (1973), p. 97-116; COOPER, J. M., 'Plato on Sense-Perception and Knowledge' (Theaetetus 184-6), Phronesis, 15 (1970), 123146, reimpresso in IRWIN, T., (ed.), Plato's Metaphysics and Epistemology, New York \& London, Garland Publishing, 1995; FREDE, M., 'Observations on perception in Plato's Later Dialogues', 
de vista da definição de conhecimento, a percepção não é cognitiva. Em relação ao primeiro ponto, Sócrates desenvolve em 184-185 um argumento que visa obter a tese de que o corpo e os sentidos são uma espécie de canal para a percepção. Platão defende aí a tese de que a mente e o corpo cooperam na percepção, mas seu ponto favorito é destacar que, na percepção, é a mente que faz o trabalho fundamental. A mente trabalha sobre os dados fornecidos pelos sentidos.

Platão também defende no argumento um contraste entre esse trabalho cooperativo entre mente e corpo e um trabalho "exclusivo" que se dá no inteiro domínio da alma. Ele parece argumentar que a natureza da alma é examinar o conteúdo da percepção ou o conteúdo de qualquer outro item não-sensível. É nesse trabalho que Platão identifica a importância da apreensão da ousia como um termo-dispositivo para qualquer estrutura de pensamento que exibe a forma $x$ é $F$.

No entanto, há uma situação curiosa defendida por certos intérpretes. Acredita-se que Platão está sendo "ambíguo" em relação a um dos termos que está no centro desse argumento, o termo "aisthesis". A situação é curiosa porque o objetivo declarado de 184-6 no diálogo é promover a desambiguação de aisthesis, sua redução a um sentido limitado de consciência, em contraste com o sentido epistemológico que foi dado ao termo na parte construtiva (151160) do argumento sobre Protágoras. Como Platão pode estar confuso sobre o significado de um termo que ele deseja esclarecer?

Penso que se Platão está expressando um argumento como uma conclusão seguida de premissas verdadeiras - e não apenas uma obscura distinção entre percepção e juízo - nós podemos saber de modo objetivo qual é o conteúdo desse argumento e, desse modo, obter uma visão clara sobre o sentido de aisthesis no argumento de 184-6. Não estou assumindo que as

in IRWIN 1995, pp. 389-94; BuRnYeat, M., 'Plato on the Grammar of Perceiving', Classical Quarterly, Vol 26, n. 1 (1976) pp. 29-51; Bostock, D., Plato's Theaetetus. Oxford: OUP, 1988, pp. 110-45; MCDoweLL, J., Plato: Theaetetus. Oxford: OUP, 1973, pp. 185-93; LORENZ, H. The Brute Within. Oxford: OUP, 2006, pp 76-94. 
premissas usadas por Platão no argumento são sem ambigüidade. Pelo menos em um caso, no argumento do objeto próprio, há dificuldades para se decidir o sentido da tese.

Em relação à ousia, parece haver também entre os intérpretes certa indecisão sobre seu sentido preciso no argumento. Mas eu vejo no texto um conceito bruto de ser que pode ser associado à idéia de koinon: a ousia é algo

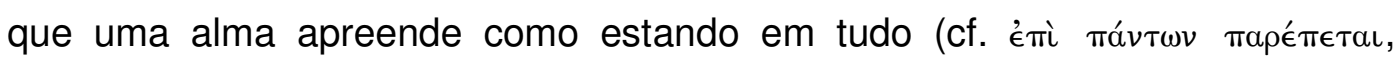
186a2) e pode ser lida como uma nominalização para ser em geral, um termo-

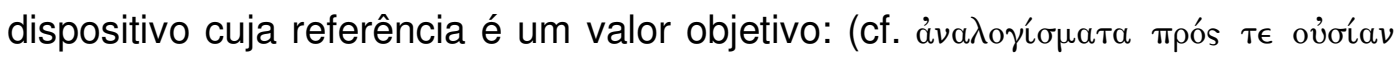

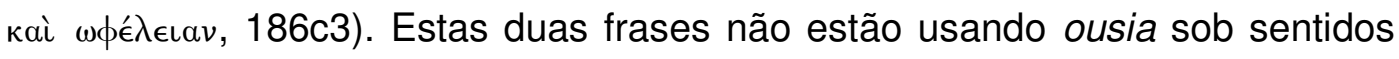
distintos e isso é reconhecido por Khan (1981) ${ }^{49}$. Khan mantém, porém, uma indecisão entre os seguintes sentidos de ousia em 184-6: (i) predicativo ( $\mathrm{S}$ is P); (ii) verídico, ousia como "verdade" ou "realidade". Kahn corretamente ampara sua análise no significado que Platão atribui à tese de Protágoras. Essa tese, no argumento que Platão Ihe dá, é interpretada como uma doutrina sobre a forma como captamos a "verdade do mundo". Como vimos na seção anterior desse trabalho, há na doutrina de Protágoras um conceito operativo de ousia que também define uma forma de captar a verdade do mundo. É esse conceito que será retomado e redefinido no argumento de 184-6.

Para vermos como Platão compreende ousia precisamos, primeiro, de uma análise do argumento. Começo pelo que considero a primeira tese do argumento: (i) o contraste entre corpo e mente.

Sócrates argumenta em 184d7-184e6 que precisamos examinar se não há algo em nós [ê้ $\tau \omega v \dot{\eta} \mu \hat{\mu} \omega]$ com o qual apreendemos, não apenas as coisas

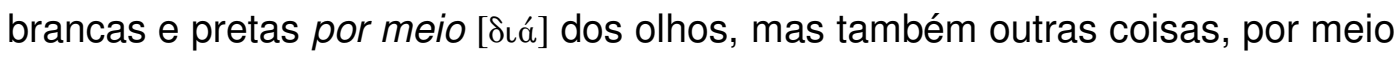

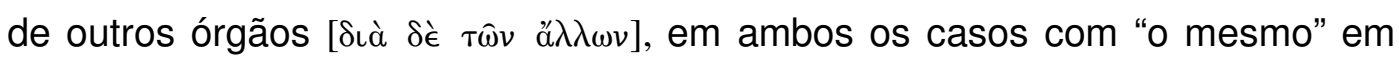

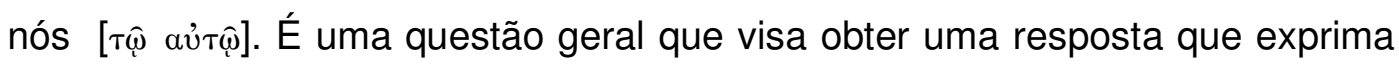
uma diferença entre as coisas que são estritas da sensação e as coisas que envolvem a alma. Mas Sócrates procede por estágios. Primeiro ele obtém de Teeteto o acordo de que existem coisas que são estritas da sensação.

${ }^{49}$ Cf. KAHN, C., 'Some Philosophical Uses of 'to be' in Plato', Phronesis 26, 1981, 105-134. 
Sócrates pergunta se as coisas por meio das quais [ $\left.\delta \iota^{\prime} \hat{\omega} v\right]$ nós percebemos 0 que é quente, duro, leve ou doce nós as classificamos como (i) pertencentes ao corpo ou (ii) a algo diferente. A reposta de Teeteto é: (i) elas pertencem ao corpo.

Nessa passagem Sócrates parece interessado na seguinte questão: $\epsilon$ "l

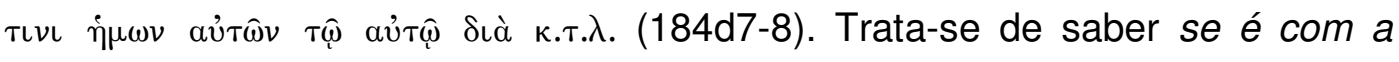
mesma [parte] de nós mesmos que certas experiências na sensação ocorrem. Essa perspectiva, em que há um "mesmo" que opera como ponto unitário a partir do qual certas coisas são apreendidas, é um importante elemento do argumento de Platão aqui. Platão entende que a sensação não tem essa capacidade de operar como um "por meio de" [ $\delta$ เá]. Burnyeat ${ }^{50}$ disse que essa tese tem certo paralelo com República 436a, onde também não temos a

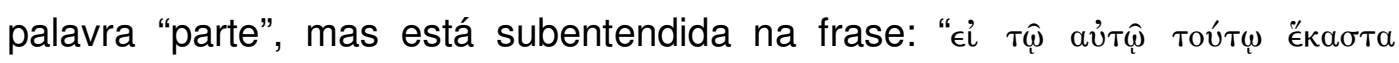

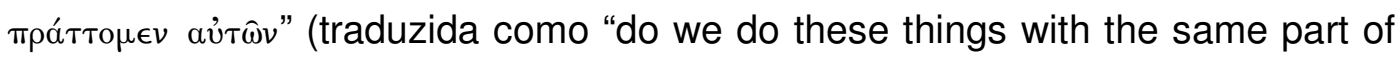
ourselves" in Cooper, Plato Complete Works; "se realizamos cada atividade graças à mesma faculdade" por A. L. A. A. Prado, 2006. ). O texto é similar a $184 d 78$ e o paralelo é sugestivo porque nas duas passagens Platão está argumentando um tipo de autonomia cognitiva da alma.

Mas há uma diferença que Burnyeat não menciona. No Teeteto esse agenciamento unitário (e singular) é contrastado com a falta de subordinação das sensações que, no trecho de 151-160, constituiu a marca do argumento de Protágoras. Na República, de outro lado, o argumento é sobre o sentido em que se pode entender a autonomia de cada uma das "partes" da alma. Se estiver certa a linha que interpreta a tripartição como "real" e não "metafórica", são duas perspectivas diferentes de alma. Por outro lado, talvez essa diferença não seja importante se lermos as duas passagens como um argumento sobre a autonomia do elemento ao qual a locução tō autō se refere. Tratar-se-ia de um argumento sobre o elemento que, em nós, é responsável pela recepção de itens não articulados.

\footnotetext{
${ }^{50}$ Burnyeat, M., 'Plato on the Grammar of Perceiving', Classical Quarterly, Vol 26, n. 1 (1976) pp. 29-5, aqui p. 37
} 
(ii) No segundo ponto importante do argumento, temos uma tese nomeada na literatura de "argumento do objeto próprio". Em 184e8-185a Sócrates requer o assentimento de Teeteto para a tese de que, se percebemos uma categoria de aspectos sensíveis por meio da visão, não podemos perceber a mesma categoria por meio da audição. Depois de Teeteto concordar, Sócrates conclui [äpa]: se há algo [ $\left[\begin{array}{ll}\epsilon^{\prime} & \tau \iota\end{array}\right]$ com que você pensa

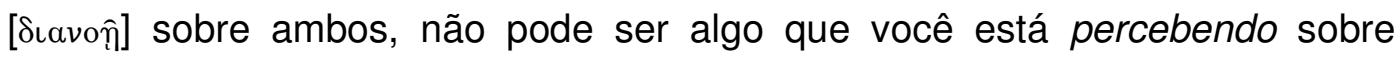
ambos, seja por meio de um dos instrumentos (órgãos sensíveis), seja por meio de outro. Teeteto confirma o raciocínio.

Há duas opções interpretativas para o que Sócrates está defendendo aqui. Vamos chamar de argumento do objeto próprio (AOP)

AOP1 - Nada que é percebido por meio da visão pode ser percebido por meio da audição, e vice-versa; o mesmo vale para outros sentidos;

AOP2 - Cores e aspectos de cores que são percebidas por meio da visão não podem ser percebidas por meio da audição; sons e aspectos de sons que são percebidos por meio da audição não podem ser percebidos por meio da visão; o mesmo vale para os demais sentidos. ${ }^{51}$

É difícil decidir, pois as duas alternativas podem ser o sentido de APO. Há algumas diferenças importantes entre elas, porém. Somente (i) assume a tese forte de que cada sentido está confinado em sua percepção própria, sendo incapaz de perceber qualquer tipo de aspecto comum a outro sentido. De outro lado, (ii) permite percepções de formas e tamanhos, que são percepções comuns, e o faz sem violar o princípio. O primeiro tem a vantagem de ser geral, argumenta Burnyeat, mas somente o segundo é verdadeiro, pois retrata uma tese correta sobre a sensação.

Uma análise do texto revelará que Sócrates não precisa de APO1 para defender seu argumento se, no final, esse argumento for, apenas, uma tese sobre a capacidade da alma como centro de reflexão e raciocínio, sem que isso implique a exclusão, da esfera da percepção, de toda forma de apreensão de aspectos gerais nas coisas. Por exemplo, na função reflexiva da alma posso

${ }^{51}$ Cf. BuRnYEAT, 1990, p. 56. 
pensar que o vermelho é um caso de uma classe de "cores". Para tanto, preciso dessa função reflexiva da alma. Mas, talvez, nos limites da minha percepção, eu possa "reconhecer" que o aspecto vermelho está em contraste com o verde, sem precisar, nesse contexto, da alma em meu uso da idéia de "contraste". Mesmo assim, isso teria que ser qualificado, pois Platão poderia argumentar que se essa percepção descamba para o pensamento da idéia de contraste, qua conceito, já não é mais sensação. Note-se que isso pode se dar no mesmo ato perceptivo. De outro lado, se Sócrates está argumentando uma tese extrema, por exemplo, que a simples percepção de um aspecto que não seja a pigmentação do vermelho, já é, como processo perceptivo, um trabalho da alma sobre a percepção, nesse caso talvez devamos assumir APO1 e afirmar que a sensação é estritamente o caso de percepção de aspectos próprios. Qualquer aspecto como forma, tamanho, relação espacial, etc., deixará de ser sensação.

Não vou optar por uma das alternativas, mas vou argumentar que não precisamos decidir isso. É um contraste que retrata um problema importante na epistemologia da percepção, mas não retrata as opções que realmente importam no argumento de Patão. Não se trata de decidir o sentido de sensação, que me parece, como vou mostrar adiante, claro o suficiente para o que Platão quer dizer, mas geral demais para certas perguntas que nós podemos fazer. O ponto no texto é saber se, na percepção, a apreensão de um aspecto bastante amplo e abstrato, como a idéia de identidade, envolve reflexão ou acontece exclusivamente no âmbito físico do corpo. No próximo tópico talvez possamos oferecer algum esclarecimento sobre o escopo da sensação nesse problema.

\subsection{O sentido de aisthesis e a análise de Cooper}

Segundo Cooper o texto que estamos examinando é indeciso sobre duas concepções de percepção: (i) percepção com certa cognição e (ii) percepção bruta, sem nada de cognitivo, nem mesmo a atribuição de nomes à percepção. A última opção define aisthesis como sensação pura, uma forma de estímulo que acontece ao corpo devido às ocorrências físicas próprias aos órgãos 
sensíveis, mas sem o tipo de consciência ou de pensamento que formulamos por meio de cláusulas que se iniciam, formalmente, por um "que". Por exemplo, percebo x, que é uma cor, mas não penso nisso no momento da sensação. Apenas vejo a cor. Mas perceber "que x é..." já não é sensação. Isso é o que Crombie chama de pensamento por meio de "that clauses". 52 A palavra "percepção" pode, portanto, ter dois sentidos: (i) um deles é carregado cognitivamente, onde se admite algum raciocínio na percepção, e (ii) o outro é desprovido de qualquer cognição. J. Cooper marcou a literatura do Teeteto ao escrever, na revista Phronesis em $1970^{53}$, um artigo no qual acusa Platão de não ter se decidido sobre esses dois sentidos. O artigo de Cooper é fundamental para se entender a interpretação do argumento de 184-6 e eu não vou disputar, nesse momento, nada além de sua interpretação de aisthesis no argumento.

De acordo com Cooper é importante sabermos qual o conceito exato de aisthesis que está em jogo em 184-6. Cooper diz que Platão "shifts from saying that a person perceives through sensory powers of the body organs (cf. $184 \mathrm{~b} 9, \mathrm{c} 6-7,8)$ to saying that $(185 \mathrm{c} 8, \mathrm{e} 6-7,186 \mathrm{~b} 3)$ the mind perceives through the senses". ${ }^{54}$ No texto, no entanto, essa mudança inexiste. Não temos a tese de que uma pessoa "percebe" por meio da capacidade sensória. O que Cooper quer dizer nessa parte da frase é que os órgãos dos sentidos são o centro da percepção. No entanto, o argumento defende que o centro da percepção é a alma.

Como já se notou em algumas análises, Cooper lê 185b9-c3 de modo apressado. Nessa passagem temos o que Sócrates considera ser um ponto adicional para argumentar a importância da alma como agente de reflexão. Ele diz: se fosse possível colocar a questão de se ambos [som e cor] são salgados ou não, a resposta deveria ser que é por meio da língua que se examinaria

\footnotetext{
${ }^{52}$ Cf. Crombie, 1963, p. 3ss.

${ }^{53}$ CoOPER, J. M., 'Plato on Sense-Perception and Knowledge' (Theaetetus 184-6), Phronesis, 15 (1970), 123-146.

${ }^{54}$ COOPER, 1970, p. 129, n. 09.
} 
esse ponto. Cooper lê: "we investigate whether a couple of things are bitter by means of a bodily power" (p. 132), argumentando que Platão não está claro aqui sobre quem é o agente da percepção, já que acaba de dizer que a sensação "investiga", quando deveria dizer que é a alma que faz isso. Platão estaria oscilando entre a hipótese dos órgãos como agentes, tal como nesse caso em que cita a língua, e a hipótese da alma como centro da percepção.

Uma análise mais atenta, contudo, não referenda a leitura de Cooper. $\mathrm{Na}$ passagem nós temos um argumento "per impossible", o que diminui a força do que Sócrates está exemplificando. Na questão se a cor e o som "são salgados ou não", o caso dativo ( $(\hat{\omega})$ usado em $185 \mathrm{c} 1$, poderia, separadamente, significar autonomia dos órgãos, na linha do que Sócrates argumentou em 184b7-d1, no

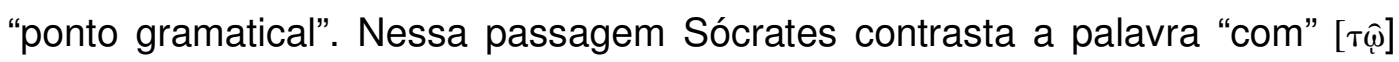
com a locução "por meio de" [ $\delta \iota$ 'ov̉]. A importância do contraste é para se perceber que quando digo que vejo com os olhos ou ouço com os ouvidos, estou destacando, consciente ou inconscientemente, que os órgãos são responsáveis pela percepção. Mas se digo que vejo por meio dos olhos ou por meio dos ouvidos, descrevo a percepção de modo mais correto, pois deixo claro que os órgãos não realizam todo o trabalho. Mas, de volta a $185 \mathrm{c}$, note-se que Platão usa "dia + genitivo" em c3 (resposta de Teeteto), o que, de acordo

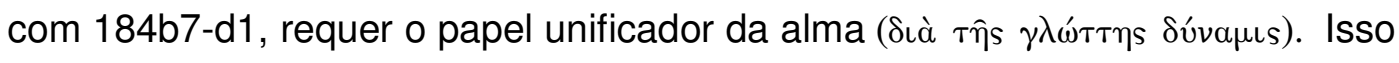
indica que Sócrates não mudou seu ponto de vista em relação ao que é argumentado no ponto gramatical, em 184b-d.

Minha leitura do argumento em 185b-c é a seguinte: se pudéssemos imaginar uma questão sobre o fato, impossível, de som e cor serem salgados, continuaríamos no âmbito da alma, mas neste caso da alma que, em cooperação com o órgão sensível da língua, unifica a experiência que chamamos "salgado". 55

\footnotetext{
${ }^{55}$ Para análises semelhantes ver Bostock, D., Plato's Theaetetus. Oxford: OUP, 1988, p. 13237; Sedley, D., The Midwife of Platonism. Oxford: OUP, 2004, p. 106. Para uma análise diferente da minha, mas também contra Cooper, ver KanaYAMA, Y., "Perceiving, Considering, and Attaining Being (Theaetetus 184-6)', OSAP 1987, 29-81.
} 
O próximo passo de Cooper deixa de lado essa hipótese da percepção como tarefa dos órgãos e passa a examinar a alternativa que a percepção é uma questão de "acts of the mind". Aqui, diferentemente do tópico anterior, Cooper explora no texto de Platão um problema genuíno. Na medida em que temos um "ato" da alma na percepção, podemos esperar alguma consciência nesse ato, isto é, algum tipo de trabalho cognitivo. Podemos, sobretudo, defender que há diferentes níveis cognitivos e que a percepção é capaz de obter pelo menos um nível. Mas, se Platão vê assim, qual o sentido da tese de que a sensação não é conhecimento? Cooper tem aqui, portanto, uma questão relevante, embora ele não possa defender que Platão é refém de uma ambigüidade.

Não estou certo se Platão entende o termo "cognição" na percepção do modo como Cooper o entende. Para Cooper cognição significa, entre outras coisas, "giving names", nomear, exclusivamente na esfera da percepção, o que está em seu alcance. Penso que em 184-6 Platão está interessado na classe de juízos que são pré-requisitos para o conhecimento. É uma classe ampla que se enquadra na categoria da doxa. Se conceder nomes ou reconhecer coisas na percepção envolve a doxa, então envolve um trabalho reflexivo que a percepção não pode fazer. O que interessa a Platão aqui, como se pode ver a partir de 187, é o trabalho cognitivo que está nesse conceito de doxa.

O ponto claro da relação entre alma e percepção é a tese de que a alma tem um papel crucial na percepção, que é o de providenciar a parte de nossa experiência perceptiva que nomeamos "consciência". Mas isso não implica carregar essa consciência com capacidades cognitivas, pois em Platão cognição é um estado mental que apreende um aspecto ou um estado de coisas sob a forma $x$ é $F$ e isso já ultrapassa os recursos da percepção. É comum hoje dizermos que milhões de experiências físicas acontecem em nosso corpo e nós sequer sabemos. Porém, como nota Bostock, "Plato can reasonably distinguish, as at $179 \mathrm{c}$, between the occurrences of theses changes 


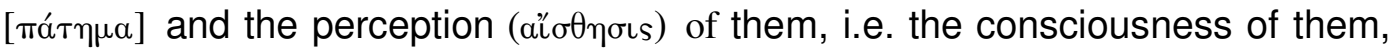
without admitting that perception includes judgement". 56

Parece que a distinção entre meras ocorrências e consciência é o pontochave da divisão de trabalho que o argumento propõe entre corpo e alma, quando estamos no âmbito estrito da percepção. É tudo o que Platão quer dizer com a tese de que a alma apreende os dados da percepção (cf. 184e). Mas em outras partes do argumento, Platão tem propósitos mais ambiciosos que envolvem a idéia de apreensão do ser na percepção. Como argumenta Fine: "his emphasis on being here is offered as part of an effort to distinguish between two models of perception, on one of which it is below the cognitive threshold and on one of which it is not'. ${ }^{57} \mathrm{O}$ primeiro modelo é o conceito protagoreano e o segundo é o conceito platônico de percepção.

(iii) Passo agora ao exame do terceiro aspecto do argumento: os koiná e a apreensão do Ser-ousia. Quero analisar essa passagem tendo República 523-5 como pano de fundo, pois penso que ali Platão expressa de forma canônica sua tese de que o pensamento tem uma natureza distinta da sensação.

A premissa do argumento sobre os koiná é expressa por meio de uma pergunta em 185a9: "Sobre o som e a cor. Antes de tudo, não pensas justamente isto acerca deles: que ambos são? (Peri dē fōnēs kai peri khroas prōton men auto touto peri amfoterōn ē dianoē(i), hoti amfotérō eston;]. Segundo Holland ${ }^{58}$, a função do argumento do objeto próprio é dar suporte à idéia que um sentido específico não é capaz de captar aspectos comuns às sensações, como o fato de um som e uma cor partilharem o mesmo predicado: ambos existem. Holland afirma que o ponto de Platão é que a existência

\footnotetext{
56 Bostock, 1988, p. 143.

${ }^{57}$ FINE, G., 'Plato on Perception', OSAP 1988 (suppl. Vol.), 15-28, p. 26.

58 Holland, A. J. 'An Argument in Plato's Theaetetus: 184-6', The Philosophical Quarterly, Vol. 23, No. 91. (1973), p. 104
} 
daquilo que ouvimos e daquilo que vemos não é em si mesmo algo que vemos ou ouvimos. ${ }^{59}$

O que o autor do Teeteto pretende mostrar com a tese que sentidos distintos não captam um aspecto como existência? Para se responder essa questão é preciso observar que a tradução da frase hoti amfoterō eston como "que ambos existem" é uma possibilidade, mas não se adapta bem ao todo do argumento de 184-6. Muitos intérpretes rejeitam essa tradução, entre os quais D. Bostock (1988), M. Burnyeat (1976) e H. Lorenz (2006). Há uma alternativa melhor. A frase de $185 a 9$ pode ser lida como a eventualidade da percepção do som e da cor como coisas definidas ou como itens que são isto ou aquilo. Se interpretarmos 185a9 nesta linha, a tradução adequada é "que ambos são", em que o complemento do verbo pode ser "isto ou aquilo". Essa tradução é provavelmente a opção que melhor retrata a tese de Sócrates sobre os aspectos que a alma é capaz de apreender acerca dos dados sensíveis. Como observa Lorenz:

A primeira coisa que alguém pensaria sobre o som e a cor, ele [Sócrates] acaba de dizer, é que ambos são ou possuem ser (hoti anfoterō eston). Nestas poucas sentenças, em 185a11-b5, o verbo 'Ser' não ocorre novamente, mas os predicados usados - 'diferente', 'o mesmo', etc. - devem ser entendidos como complementos a eston [são, existem] em 185a9. ${ }^{60}$

Lorenz argumenta o que tem sido um consenso nos trabalhos de Kahn, Owen e L. Brown sobre o verbo ser em grego. ${ }^{61}$ Frases sem complemento podem ser elípticas. $\mathrm{Na}$ frase "Sócrates ensina" podemos

\footnotetext{
59 HolLAND, 1973, p. 105. Holland considera outra alternative: "Plato may have in mind "apprehending that $\mathrm{x}$ exists" or even "apprehending that $\mathrm{x}$ is $\mathrm{P}$ ". I am not confident that we can speak of his having one or other of these definitely in mind." (p. 107)

${ }^{60}$ LORENZ, H. The Brute Within. Oxford: OUP, 2006, p. 79.

${ }^{61} \mathrm{O}$ artigo de L. Brown (Brown, L., 'Being in the Sophist: a syntactical enquiry', OSAP, 4 (1986), 49-70) é capital para uma mudança na forma de se entender o contraste completoincompleto no uso do verbo. Basicamente se passou de uma disjunção "completo ou incompleto" para um cruzamento entre os dois usos. O uso completo não se destina a captar o aspecto existencial em oposição à predicação. Ele pode ser complementado.
} 
perguntar "ensina o quê?" e a resposta irá colocar ali um complemento. O mesmo pode ser feito na frase de 185a9: as frases "que ambos são" ou "que ambos existem" podem chamar as perguntas "são o quê?", "existem como?". Quando Sócrates diz, portanto, que acerca da cor e do som os sentidos não podem apreender "que ambos são" ou "que ambos existem", podemos interpretar a tese da seguinte forma: o pensamento sobre aspectos comuns para coisas distintas é uma atribuição da alma. Entre os aspectos comuns ( $\tau \grave{a}$ кoเvá) que a alma focaliza sobre a cor e o som o argumento dispõe: que são diferentes entre si, mas idênticos a si (185a11), em conjunto são dois e separados são um (185b2), possuem aspectos de semelhança e nãosemelhança (185b4-5). Note-se que na pergunta de Sócrates estão presentes três elementos: (i) som; (ii) cor e (iii) o predicado comum: ambos são/existem. A primeira coisa que a alma percebe em sua tarefa reflexiva é que os dois itens, som e cor, possuem alguma característica específica, o som é isto ou aquilo, a cor é isto ou aquilo.

Vista desta perspectiva, a passagem seguinte, que menciona explicitamente o princípio dos opostos, torna-se relevante:

Percebo a dureza do que é duro por meio do toque e a leveza do que é leve do mesmo modo, não é isto mesmo? Sim. Mas seu ser e que ambos são, e sua oposição um ao outro, e o ser mesmo desta oposição, são coisas que a alma, por si mesma, tentar decidir para nós, analisando-as e comparando-as entre si $(186 \mathrm{~b} 2-10)^{62}$

A expressão "por meio de" (cf. 184c6-7: $\delta \iota$ 'oû) indica que é a alma, por meio dos sentidos, que percebe a dureza. Pensemos na passagem dos três dedos, em República 523-5, onde a frase "algumas [sensações] não convidam a inteligência à reflexão, como se lhes fosse suficiente o julgamento feito pela sensação." Aqui Platão parece precisar (e não modificar) a descrição da República, pois a sensação do que "é duro" ou "é mole" na República é não-

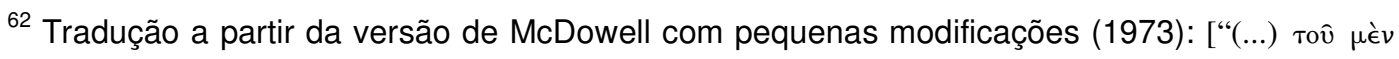

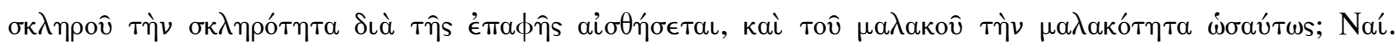

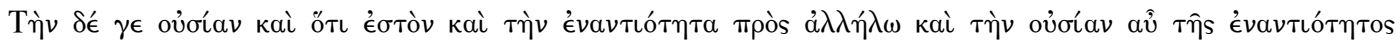

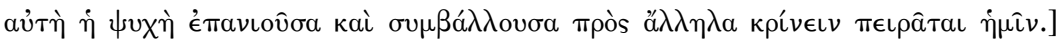


problemática até que a alma aplique no exame dessas propriedades o que está no coração do princípio dos opostos, citado aqui: o estudo das identidades e dissimilaridades dos itens. Esse passo leva o percipiente ao núcleo do "ser da oposição", como relata Sócrates aqui.

Evidência de que é disso que se trata é o fato que os mesmos predicados usados na passagem dos três dedos estão aqui no Teeteto. A única diferença é a cláusula "por meio dos sentidos" em 184c6-7, ausente da República, mas sem grandes conseqüências para aquele argumento, pois não se deve supor que ao imaginar uma situação não-problemática na sensação Platão conceba que a alma não está envolvida.

A menção ao ponto gramatical (diferença entre perceber com os sentidos e perceber por meio deles) só é importante no contexto onde se quer opor a exata diferença entre uma tese platônica sobre o que significa pensar com os recursos próprios da alma e uma tese protagoreana que insiste na validade do testemunho dos sentidos. Mas num contexto onde se trata de determinar que tipo de situação específica, na sensação, pode requerer o

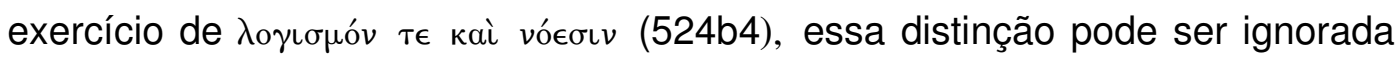
sem grandes conseqüências. De fato não é essa distinção que ampara o argumento sobre a percepção das propriedades essenciais na República, tampouco o é no Teeteto, mas a tese que só se pode pensar nas propriedades a partir do momento que a alma exerce a reflexão que caracteriza o $\lambda$ o c $\sigma \mu o ́ v$ no princípio dos opostos: a percepção de relações de identidade e relações de diferença. ${ }^{63}$

\footnotetext{
${ }^{63}$ Cf. República 524. Isso não significa que a distinção não seja relevante em 184-6. Burnyeat fez uma excelente análise disso (BuRnYeat, M., 'Plato on the Grammar of Perceiving', Classical Quarterly, Vol 26, n. 1 (1976) pp. 29-5), praticamente estabelecendo um marco nos estudos do Teeteto. O que estive chamando de "ponto gramatical" é introduzido com certa cerimônia quando Sócrates diz que a atenção aos termos e expressões verbais ( e não aos referentes dos termos e expressões - é, em geral, sinal de má formação. Tendo expresso isso, Sócrates diz que vai permitir uma exceção para introduzir a diferença entre sentir com $(\hat{\omega})$ os olhos ou ouvidos e sentir por meio ( $\delta i$ ov̉) dos olhos ou ouvidos (cf. 184c).
} 
$\mathrm{Na}$ passagem dos três dedos a tese de base é que as oposições surgidas no âmbito da sensação incitam a alma à reflexão. A alma verá que tais oposições são idéias que correspondem a referentes distintos, exatamente o ponto do princípio dos opostos, o qual diz que forças ou idéias contrárias não podem habitar o mesmo sujeito na mesma relação. ${ }^{64}$ Penso que o que está em jogo nestas formulações sobre opostos é a tese platônica que a razão é uma capacidade que, ou está inerte na alma, ou está atuando em sua potência máxima, a habilidade de determinar o ser, as relações e as oposições. Se a percepção não traz contradições, como é o caso da visão de um "dedo" qua dedo, faz sentido dizer que a alma não atua e que o que a sensação retrata

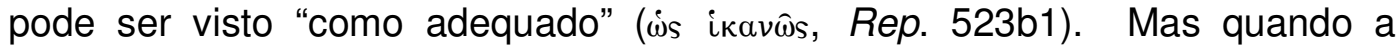
sensação apresenta contradições, tais informações só são "contraditórias" do ponto de vista desta apreensão inicial, que é sensível. Deixam de sê-lo, com efeito, no momento que a alma se debruça sobre elas e estuda as oposições e o "ser mesmo das oposições", como diz Sócrates na passagem do Teeteto mencionada acima. ${ }^{65}$ Voltarei ao argumento da República 523-5 mais adiante.

\footnotetext{
${ }^{64}$ Cf. República IV. Os comentadores procuram se debruçar sobre o Princípio dos Opostos (ou Princípio dos Contrários, como prefere BOBONICH in: Plato's Utopia Recast, 2002) para tentar entender 0 que está em jogo na tese que a alma possui três gêneros $(\epsilon i \delta \eta)$. $O$ texto que expressa o princípio é o que segue. "É evidente que o mesmo sujeito não poderá, ao mesmo tempo, fazer e sofrer coisas contrárias, pelos menos no mesmo sentido e em relação à mesma

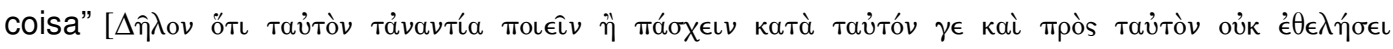
ă $\mu$, 436b9-10] (trad. de A. L. A. A. Pradol in: Platão, A República. São Paulo: M. Fontes, 2006). $\mathrm{O}$ trecho "Dēlon hoti tauton tanantia poiein è paschein... ouk ethelēsei hama" expressa a tese geral do princípio. Numa tradução literal seria "é evidente que o mesmo não poderá fazer e sofrer contrários ao mesmo tempo". As cláusulas "katà tautón ge kaì pròs tautòn" o qualificam: no mesmo e em relação ao mesmo.

${ }^{65} \mathrm{~J}$. MOLINE discute de forma bastante sensata República 523-5 e outras passagens clássicas sobre o conceito de Forma e o que está pressuposto aí. Cf. Moline, J. Plato's Theory of Understanding. Wisconsin: The University of Wisconsin Press, 1981, sobretudo pp. 79-117. Ele argumenta que não temos "argumentos" para a existência das Formas no corpus, mas passagens onde elas são assumidas.
} 


\subsection{O conceito de ousia em Platão}

Toda essa análise sobre as relações entre percepção e apreensão de aspectos comuns no Teeteto nos faz indagar se Platão possui uma perspectiva comum sobre apreensão da ousia entre os diálogos Fédon, República e Teeteto. O que me parece claro é que Platão tem a mesma tese sobre por que a sensação não pode captar a estrutura predicativa que aplicamos às coisas do mundo. Resta saber se o modo como Platão entende essa idéia de predicação sofreu alguma alteração entre aqueles diálogos. Precisamos primeiro examinar o conceito de ousia de uma perspectiva mais ampla.

Quando examinamos o conceito de ousia em Platão nos deparamos com um termo que cobre duas classes de coisas: (i) aqueles itens que "possuem ser", que são isto ou aquilo e (ii) certa figuração no mundo que se refere ao que, na filosofia contemporânea, denomina-se "fatos". O que vou defender foi argumentado por Kahn. ${ }^{66} \mathrm{O}$ segundo sentido que dei à ousia acima sugere que em Platão ousia é um termo-dispositivo (device) para certa configuração objetiva e real do mundo. Embora, em alguns casos, o uso de ousia faz referência à verdade enquanto propriedade de sentenças, em geral o termo não tem esse significado, mas apresenta o sentido de "realidade" ${ }^{67} \mathrm{~A}$ questão, como não podia deixar de ser, é controversa na literatura. Há uma linha que interpreta ousia em Platão conforme a crítica de Aristóteles a Platão, expressa na Metafísica. Nessa linha ousia tem o sentido de "essência" e significa "universal". Ler ousia em Platão como "universal", no entanto, tem alguns problemas.

\footnotetext{
${ }^{66}$ Cf. KAHN, C., 'Some Philosophical Uses of 'to be' in Plato', Phronesis 26, 1981, 105-134, aqui pp. 119-120. Ver também a interpretação da Teoria das Formas apresentada em KAHN, C., Plato and The Socratic Dialogue.Cambridge, CUP, 1996, pp. 331-370.

${ }^{67}$ Ver a respeito MASON, A. 'The Good, Essences and Relations', in Pursuing the Good: Ethics and Metaphysics in Plato's Republic, ed. by Cairns, D., Herrmann, F. G., and Penner, T., Edinburgh Leventis Studies 04, 2007, p. 199.
} 
Allen ${ }^{68}$ nota que nos universais há uma diferença entre o que nomeamos "teoria sobre universais comutativos" e as Formas platônicas. Para Allen a Forma platônica é uma entidade real, um puro ser, independente de qualquer mente ou qualquer época, característica que os universais não possuem. Haveria, então, um problema para quem entende que, no platonismo, $x$ contém $F$ porque $x$ é uma instância particular de uma propriedade $F$, cujo conceito coincide com o que nomeamos "universal". Allen procura rebater essa interpretação da seguinte forma. As Formas não podem ser um universal porque os universais são menos concretos que os particulares, e as Formas não podem ser menos concretas que os particulares. Allen diz também que nos universais a relação entre gênero e espécie é uma relação de algo mais abstrato para algo mais concreto. A propriedade universal "vermelho", entendida como propriedade lógica abstraída da multiplicidade de tons que exibem esta qualidade, é menos real que este ou aquele vermelho que vemos. Para Allen esse aspecto está em conflito com uma característica das Formas platônicas: elas possuem "mais ser" que as coisas das quais elas são a unidade. Dada a interpretação da Forma como universal, porém, teríamos o caso, em Platão, de um universal mais real que suas instâncias, o que implica pensar que na teoria das Formas de Platão os gêneros são mais "concretos"69 que as espécies.

$\mathrm{O}$ argumento de Allen tem um dado interessante em relação a Aristóteles. Ele claramente retira seu argumento da tese aristotélica de que os universais não são substâncias. Mas Allen retira também uma lição diferente daquela exposta nos argumentos de Metafísica A6, A9, M4 e M9. Aristóteles não argumenta que as Formas não são universais. Ele parte das Formas como universais e argumenta a partir daí que elas não podem ser substâncias

\footnotetext{
${ }^{68}$ Allen, R. E., 'Participation and Predication in Plato's Middle Dialogues', The Philosophical Review, Vol. 69, No. 2 (1960), pp. 147-164.

${ }^{69}$ Há uma linha em que se pode pensar na origem desse aspecto "concreto" como uma idéia primitiva do verbo Ser nos gregos. Ver a respeito KAHN, C. 'Retrospectiva do Verbo Ser e do Conceito de Ser', in: Sobre o verbo grego ser e o conceito de ser. Trad. Maura Iglesias e al. Rio de Janeiro: Núcleo de Estudos de Filosofia Antiga, Departamento de Filosofia da PUC-RJ, 1997, pp 155-195, sobretudo pp. 156-7.
} 
aristotélicas. Allen usa o "espírito" da crítica de Aristóteles para negar uma leitura que Aristóteles considera, sob certas condições, válida: as Formas como universais.

Os argumentos de Allen são, no entanto, plausíveis, pois refletem um aspecto da discussão platônica das Formas: o aspecto aprendido de Parmênides: se $x$ é $F$ e x é um particular, a sentença "x é F" não se fundamenta logicamente nos atributos de $\mathrm{x}$, mas na natureza de $\mathrm{F}^{\text {dade }} .70$

Há outra razão para rejeitarmos a interpretação das Formas e do conceito de ousia como referência a universais. Trata-se de um importante aspecto do є̌ $\lambda \in \gamma \chi$ os, notado por Nehamas ${ }^{71}$. Segundo Nehamas, é falso afirmar que os interlocutores de Sócrates oferecem respostas inadequadas às perguntas socráticas porque, enquanto Sócrates está requerendo um aspecto geral para "justiça", "beleza", "coragem", etc., os interlocutores propõem instâncias ou particulares (este x é belo, aquele y é corajoso). Nehamas argumenta que os interlocutores geralmente oferecem respostas que apresentam certo grau de generalidade. Cito como exemplo (semelhante aos casos estudados por Nehamas no corpus platônico) a definição de justiça

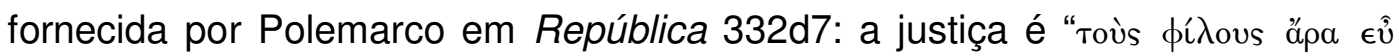

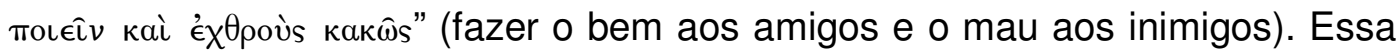
resposta não cita um token (ocorrência) de justiça, mas um type, uma definição geral (universal). Conforme a definição, todos os casos que se enquadram na fórmula são casos de justiça. Sócrates critica a definição mostrando que ela exibe propriedades contrárias (fazer o mal e fazer o bem). A idéia de que a definição falha porque não garante uma pureza na fórmula (pois compreende

\footnotetext{
${ }^{70} \mathrm{Cf}$. "In the Phaedo, Socrates holds that the $\mathrm{F}$ itself can never be not- $\mathrm{F}$ and that it is the single explanation of why all $F$ things are $F$. He considers these two ideas as jointly necessary and sufficient conditions for an adequate definition of the $F$ itself", NeHAMAS, A., "Confusing Universals and Particulars in Plato's Early Dialogues" The Review of Metaphysics, Vol. 29, No. 2 (1975), pp. 287-306, aqui p. 301, n. 17. As Formas aí são, claramente, um paradigma. Para uma análise dos problemas que decorrem dessa tese das Formas como Paradigmas, ver o estudo de Zingano, M., "Auto-Predicação, Não-Identidade, Separação", Analytica vol. 3, n. 2, 1988, pp. 241-259.

${ }^{71}$ Em "Confusing Universals and Particulars in Plato's Early Dialogues", cf. nota anterior.
} 
aspectos contrários), tem uma infinidade de variações nos argumentos dos diálogos, mas é raro o caso em que o argumento socrático identifica no argumento do interlocutor a noção de particularidade, individuação ou instância de uma propriedade como a razão pela qual a resposta não é validada.

Segundo Nehamas, Sócrates quer a compreensão da "unidade" do tema e não o entendimento da universalidade. Uma fórmula como a de Polemarco, nesse aspecto, é tão geral que reúne o que é familiar ao conceito de justiça e o que é familiar ao conceito de injustiça (os inimigos). A resposta não pode fornecer uma fórmula tão geral, pois precisa cumprir a exigência parmenídica da $\mathrm{F}^{\text {dade }}$, que requer que a definição seja explanatória de todos os casos de $\mathrm{F} e$ não contenha em si mesma nenhum aspecto que represente não-F.

\subsection{Ousia e Sensação}

Para Platão a sensação não está apta a lidar com a apreensão da ousia. Por isso a alma se encontra em estado de aporia diante das contrariedades sensíveis quando se vê na necessidade de decidir se determinado objeto é pequeno ou grande. Na República, na passagem que citamos acima, Platão argumenta que a alma precisará determinar se cada informação recebida

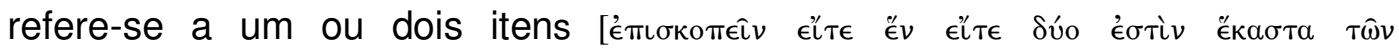
$\left.\epsilon i \sigma \alpha \gamma \gamma \in \lambda \lambda_{0 \mu} \mu^{\prime} v \omega \nu\right] "$. Esse estudo tem por foco as informações recebidas na sensibilidade: pequeno, grande, mole, duro, pesado, leve. Não há impasse na experiência com estas sensações se os sentidos retratam a sensação de uma perspectiva não-problemática. Quando sinto que alguém pega em meu braço posso relatar tal experiência na frase "uma mão pesada me tocou!" Neste caso há várias formas de indecisão que podem ocorrer. É preciso certa pressão da mão em meu braço para que a experiência seja sentida dessa maneira. Por outro lado, posso não conseguir determinar se o que me tocou é uma mão grande ou pequena, leve ou pesada. Segundo Platão, quando estou nesta situação, minha alma se depara com itens de uma natureza distinta da sensação, porque "grande" e "pequeno" são idéias que possuem uma realidade. Se se trata de pensar a razão pela qual algo é grande ou pequeno, pode-se dizer que a alma "se depara" com o referente de tais predicados. 
Nesta condição, ela se pergunta se há algo ao qual o predicado "grande" se refere e se há algo ao qual o predicado "pequeno" se refere.

Posso alegar que minha inaptidão para decidir se agora faz calor ou faz frio nem sempre é uma ocasião especial para a reflexão sobre a natureza (€îঠos $)^{72}$ dos predicados "quente" e "frio". Mas Platão poderia responder que quando alguém se põe a pensar se determinado objeto é grande ou pequeno, é possível que ele já tenha se deparado com tais predicados e não precise, no momento presente, refletir como na primeira vez. Neste caso sua sensação lhe permite formular o juízo "a mão que me tocou é pesada". ${ }^{73}$ Mas permanece

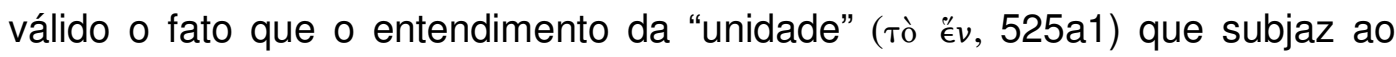
predicado "pesado" ou ao predicado "leve" é uma categoria de pensamento cuja compreensão se obtém de modo imperfeito pelos sentidos, ainda que, como claramente testemunha a passagem 523-5, seja em contextos sensíveis que a alma se torna consciente disso. Platão mostra que para se identificar o tipo de entidade que define a natureza daqueles predicados é preciso permitir que a alma seja despertada para esse problema. Analisemos a seguinte passagem:

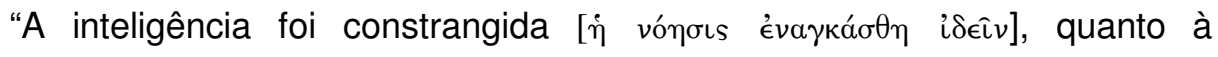
grandeza e à pequenez, a vê-las não confundidas, mas distintas, em oposição ao que acontecia com a vista”. (...) Pois bem. Era isso que tentava falar há pouco,

\footnotetext{
${ }^{72}$ Cf. Eutífron 6d11, Mênon 72c7 (citados a partir de COOPER, 1997.)

${ }^{73}$ No Teeteto 184-6 Platão argumentará que é uma alma que faz esse juízo a partir dos dados da sensação. Os comentadores que vêem nessa passagem do Teeteto uma diferença em relação à República parecem ignorar o seguinte. O fato de uma alma ser responsável pelo juízo na percepção não diz nada a respeito da validade desse juízo. Platão está descrevendo as funções da alma em relação ao que ocorre na percepção e em relação ao pensamento por meio de entidades formais. Ele não diz nada ainda sobre a correção dos juízos perceptivos da alma. Na segunda parte do diálogo é que esse tema será examinado a partir de uma noção de

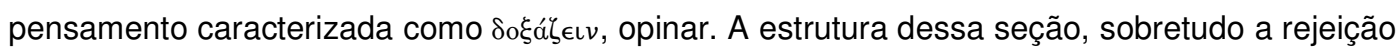
das cinco hipóteses sobre a opinião falsa, revela duas coisas: (i) Platão considera complexa a explicitação da gênese do erro; (II) ele distingue a partir de 184-6 a descrição do pensamento como capacidade de se valer de entidades formais para dizer o que é o caso e a explicação do que ocorre na alma quando essa capacidade não obtém o conhecimento. Em 184-6 Platão só trata do primeiro aspecto. Na seqüência do diálogo o segundo ponto é então examinado.
} 
quando dizia que certos objetos incitam a inteligência e outros não, definindo como incitantes os que atingem um sentido e simultaneamente os sentidos opostos e, de outro lado, dando como incapaz de despertar a inteligência tudo que não o atinge" (524c-d)

A tese de que a gênese do pensamento está na apreensão mental de qualidades contrárias é muito clara aqui, pois Platão diz que apesar de a visão ver a grandeza e a pequenez (que $x$ é pequeno, que x é grande, etc.), a percepção não consegue discerni-las. Ela as conjuga ou confunde (cf. 524c4:

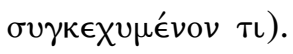

Alguns comentadores observam que há certas diferenças importantes nessa passagem da República 523-5 e no argumento do Teeteto em 184-6. Nas situações em que a razão não está atuante, i.e., de acordo com 523-5, nos casos que a percepção não é problemática, Platão parece conceder que algum tipo de articulação ou expressão é possível na sensação. Isto é "sugerido" na frase do texto que destacamos acima: "como se lhes fosse suficiente o julgamento feito pela sensação (523b1)". ${ }^{74}$ Cooper e Lorenz estão convencidos de que essa frase e alguns aspectos da forma como Platão argumenta a passagem dos três dedos mostra o comprometimento de Platão com a tese que a sensação tem autonomia na percepção, i.e., ela expressa predicados a partir de seus recursos. Platão estaria corrigindo isso no Teeteto 184-6.

Quanto ao Teeteto, eu creio ser claro que à sensação não é permitido formular nenhuma forma de predicação (x é y), mas me parece que Cooper, Burnyeat e Lorenz exageram o papel da autonomia predicativa da sensação na passagem da República. Cooper diz que Platão, em vários momentos do argumento de 523-5, retrata os sentidos como capazes de expressar isto ou aquilo. No entanto, o significado dessa sugestão não me parece ser literal, pois não creio que Platão esteja atribuindo isso à percepção enquanto capacidade. Burnyeat $^{75}$ tentou tornar aceitável a análise de Cooper ao propor que na República Platão não foi capaz de argumentar as deficiências da sensação a

\footnotetext{
${ }^{74}$ Cf. COOPER, 1970, p. 145. Ver também LORENZ, 2006, pp. 88-94.

75 1976, pp. 35ss
} 
partir de uma concepção unificada da alma, como no Teeteto, por causa de seu comprometimento com a tese da tripartição. Os dois temas, no entanto, são distintos. A tripartição é uma tese sobre a difícil convivência entre as exigências da razão e a natureza das tendências apetitiva e emocional da alma. Embora nada impeça que Platão esteja, em 523-5, pensando nas conseqüências do argumento da tripartição, desenvolvido no livro IV, o ponto que ele deseja expressar em 523-5 pode ser defendido tanto da perspectiva de uma alma unificada como na linha da tripartição. Podemos sintetizar esse ponto do seguinte modo: é um fato trivial que nos contextos sensíveis as propriedades pesado, leve, etc., são vistas, ora como $F$, ora como não-F. É também comum encontrarmos casos em que a sensação testemunha a presença de um dedo, uma casa ou um homem sem que a razão entre em apuros. Mas no momento que essa tranqüilidade é perturbada por questões relativas à natureza daqueles predicados, convém abandonar a inércia da sensação para examinar com rigor do que se trata.

No Teeteto, por outro lado, Platão examina a sensação como capacidade e ali, de fato, ele não concede aos sentidos o uso dos termos empregados na

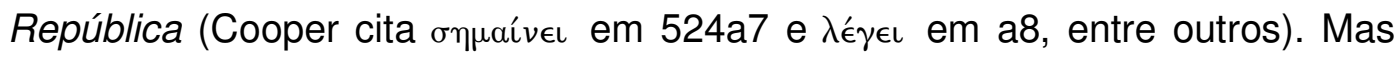
note-se que esse exame tem uma motivação que não se assemelha aos problemas da tripartição. Trata-se da teoria da sensação protagoreana.

Em suma: se Platão não exprimiu em 523-5 uma tese rígida sobre a capacidade cognitiva da sensação, daí não se segue que sua intenção no Teeteto, ao professar tal tese, seja corrigir a República por não tê-lo feito. No Fédon, que examino adiante, ele já tinha mostrado que a sensação, em si, não é cognitiva. Em alguns pontos a análise do Teeteto é mais sofisticada. Platão pode estar apresentando uma análise específica e detalhada, em contraste com o argumento sintético de 523-5.

\subsection{A confiança no procedimento das definições}

Há certa conexão entre ousia e o tema das definições em Platão. A ousia é uma propriedade ou um complexo de características que são reais. A definição 
é um logos que visa exprimir este aspecto. Platão argumenta no Teeteto que é possível definir uma propriedade do conhecimento.

A importância das definições no conhecimento foi reconhecida por Aristóteles, que julga que uma definição é um procedimento de investigação cuja meta é exprimir o que é universal, razão pela qual Sócrates foi tão incisivo sobre sua importância. Sócrates pensava que a definição era um meio de exprimir aquele aspecto que o indivíduo deve compreender se manifesta a pretensão, consciente ou inconsciente, de conhecimento do tema, como é o caso dos interlocutores dos diálogos socráticos. Para Aristóteles, como para Sócrates, não é possível atingir o conhecimento sem a apreensão desse elemento geral nomeado "каөódov" (universal). ${ }^{76}$ Neste aspecto, Platão e Aristóteles seguem os passos de Sócrates.

Creio que o desenvolvimento que Platão deu ao socratismo acrescentou ao universal um refinamento: o que é universal, em Platão, é um paradigma que tem as características de um puro ser, uma idéia que está associada ao conceito de Forma. Mas quando menciona, no Teeteto, a tese da prioridade da definição, Platão parece querer apenas explorar esse aspecto de sua teoria das Formas: há numa propriedade - no Teeteto se trata de uma propriedade do conhecimento - possível de ser identificada por meio do én $\lambda \in \gamma \chi$ os.

Já se defendeu que o sentido dessa propriedade nos diálogos é um significado, uma noção comum que preside o uso de um termo. Tratar-se-ia, no Teeteto, de esclarecer o significado do termo conhecimento em todos os contextos de saber. É provável, porém, que Platão não estivesse interessado no significado ordinário de tais termos. Se os diálogos socráticos e o Teeteto estivessem interessados na semântica dos termos, o resultado final de qualquer investigação socrática não poderia pretender algo mais ambicioso do que uma lista dos sentidos correntes de palavras como conhecer, justiça ou virtude, mais ou menos nos moldes daquilo que um dicionário oferece. Se as perguntas socráticas estivessem voltadas para o depósito de informações

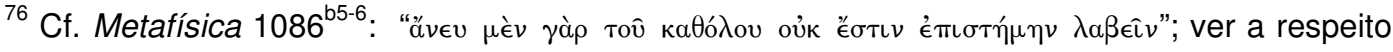
SHIELDS, C. 'Plato and Aristotle in the Academy', in: Fine, G. (ed.), The Oxford Handbook of Plato. Oxford: OUP, pp. 504-55, aqui p. 508.
} 
socialmente aceitas que os dicionários descrevem, poderíamos legitimamente questionar o pressuposto do socratismo, pois o que ele estaria propondo seria um inventário do que já está na prática lingüística da comunidade. Pelo que se pode observar nos diálogos, todavia, Sócrates e Platão parecem se preocupar com os aspectos que presidem ou informam esse uso a partir do que é ditado pela própria estrutura do item investigado.

O parágrafo anterior já sugere uma interpretação para o conceito de ousia em Platão. Essa interpretação aproveita o que há de mais firme no ‘’ $\lambda \epsilon \gamma \chi$ s $^{\circ}$ : uma clara oposição entre um perspectiva realista e as demais, sejam nominalistas, generalistas ou de tal e tal tipo. A ontologia platônica é realista com base no seguinte argumento: no estado de coisas em que "branco" é verdadeiro de um objeto, uma análise nos revela dois itens distintos: (i) "branco" se refere a uma propriedade e (ii) o objeto é um particular. Uma ontologia platônica defenderá que "branco" se refere a uma propriedade existente que está numa relação $\mathrm{R}$ com um objeto. Esta relação retrata um esquema ontológico povoado por, pelo menos, duas entidades: propriedades e objetos.

Numa interpretação clássica do platonismo, essa ontologia reduziria os objetos a itens desprovidos de qualquer característica "em si". Tal interpretação, porém, não é plausível se defende a negação de aspectos aos objetos da experiência ordinária, o que atribuiria a Platão uma ontologia de predicados sem "coisas". Defendi, na análise de 151-6, que o protagoreanismo é escolhido por Platão para ser a ontologia que pretensamente descreve predicados sem "coisas" ou sem "sujeitos".

Uma ontologia nominalista, de outro lado, procurará negar existência às propriedades e assumirá que a entidades genuínas são os particulares, sejam substâncias ou qualquer outra forma de itens que não se definam como idéias. ${ }^{77}$ Nessa ontologia as propriedades são universais ditos (verdadeiros de) de particulares.

\footnotetext{
77 Cf. Hochberg, H., 'Nominalism, Platonism and "Being True of"', Nous, vol. 1, n. 04 (1967), pp. $423-419$.
} 
O mencionado realismo sobre as propriedades tem, para Platão, a seguinte justificativa: devemos optar pela descrição de um universo de entidades inteligíveis mais firmes e epistemologicamente confiáveis que aqueles aspectos derivados de uma prática nominalista ou das crenças cambiantes. Há duas fontes básicas de uma prática nominalista: a subjetividade e o conjunto de crenças sociais. Platão rejeita ambas. Como escreve Nicholas White:

"Nor does Plato believe that ordinary opinion or usage is a reliable guide on questions of particular application of terms to objects. There is no sign of the view that the mere fact that a particular action is called "just", say, is by itself sufficient ground for saying that it is just or that the term "just" is in fact true of it". ${ }^{78}$

O Teeteto não discute o significado desse pressuposto que vou chamar de "realismo das propriedades definidoras", mas o diálogo claramente veicula a confiança na tese de que o conhecimento tem uma propriedade real. Essa confiança é típica dos diálogos socráticos. Quando investiga um tema Sócrates parece assumir que há uma propriedade na constituição ou na estrutura do item e a pergunta "o que é?" está, precisamente, requerendo ao interlocutor a compreensão e a explicitação dessa propriedade. É um procedimento que reaparece no Teeteto, o que leva muitos comentadores a notarem, como Bostock, que o Teeteto exibe em suas linhas "the life and sparkle of many of Plato's earlier writings". ${ }^{79}$ A similaridade mais óbvia com os diálogos socráticos é, talvez, o fato que o tema central segue a fórmula "o que é $x$ " e no corpo de cada resposta há um conjunto de teses que fracassa na tentativa de expressar a natureza de $\mathrm{x}$.

Um aspecto importante nesse espírito socrático que o Teeteto exibe é a rejeição de respostas à questão central que "enumeram" ou "listam" tipos de itens na tentativa de responder ao problema posto por Sócrates. Já vimos que esses itens descartados raramente são tokens e geralmente são types. $O$ Teeteto não foge à regra. É o entendimento desse aspecto que penso estar em jogo na definição de barro (146d-147c) e no exercício sobre as potências

\footnotetext{
${ }^{78}$ WHITE, N. P., Plato on knowledge and Reality. Indianapolis/Cambridge: Hackett, 1998 [1976], p. 16

${ }^{79}$ Bostock, D., Plato's Theaetetus. Oxford: OUP, 1988, p. 12.
} 


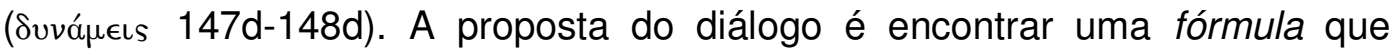
apresente os aspectos do conhecimento numa definição que não admita aspectos contraditórios, como o não-conhecimento, o falso e, se pudermos atribuir a Platão a parte positiva da terceira definição, deveríamos acrescentar também o aspecto circular, i.e., se há uma distinção entre opinião verdadeira e opinião verdadeira + logos, os aspectos definitórios desta última fórmula não podem se basear nos aspectos que caracterizam a primeira.

\subsection{A rejeição das espécies de conhecimento}

A rejeição das espécies de conhecimento indica a confiança numa propriedade unitária do saber. De um modo geral, no Teeteto Sócrates argumenta que a questão do diálogo consiste na busca de uma fórmula que seja capaz de exibir o elemento comum da idéia de conhecimento. Uma enumeração ou lista de conhecimentos não poderá mostrar essa propriedade, o que não significa que determinada espécie de lista não seja uma resposta plausível à pergunta o que é conhecimento em outros contextos. O que vemos no argumento do Teeteto, no entanto, é a negação de que a menção a casos de conhecimento como geometria, arte, matemática, seja um procedimento tão informativo quanto a apresentação de uma fórmula que descreve uma propriedade essencial do item em questão.

Essa tese aparece de modo evidente no momento que Teeteto responde à pergunta do diálogo com a sugestão de que a geometria e as atividades dos artesãos são conhecimento (146c-d). Sócrates alega que Teeteto é "generoso"

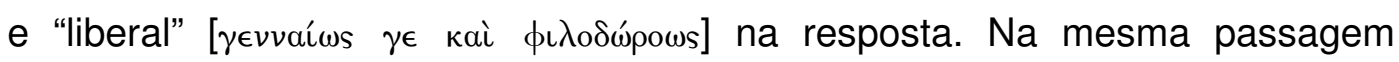
Sócrates diz que a resposta de Teeteto oferece uma variedade em lugar de

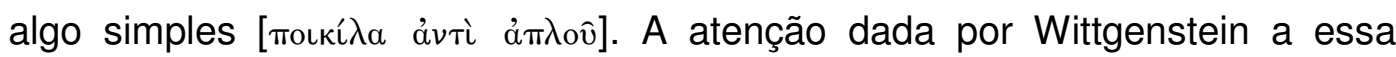
passagem ${ }^{80}$ gerou uma literatura sobre a rejeição dos exemplos nas perguntas socráticas. Wittgenstein julga que Sócrates rejeita com muita pressa a resposta de Teeteto. Para Wittgenstein, a atitude de Sócrates é suspeita porque, provavelmente, não há uma essência de conhecimento que presida a unidade

\footnotetext{
${ }^{80}$ Cf. WittgensteIn, The Blue and Brown Books. Oxford, 1958, 20.
} 
das espécies de saber citadas pelo jovem matemático, as quais, note-se, já estão num nível de generalidade que pode, conforme o que Wittgenstein considera suficiente, representar uma resposta geral à pergunta de Sócrates. Seguindo a crítica de Wittgenstein, Peter Geach ${ }^{81}$ identificou no $\epsilon^{\prime} \lambda \epsilon \gamma \chi \chi^{\circ}$ as seguintes teses:

(i) Se estou predicando determinado termo ' $\mathrm{T}$ ' corretamente, devo 'conhecer o que é ser T' no sentido de ser capaz de oferecer um critério geral para $\mathrm{T}$;

(ii) Não há nenhuma utilidade em tentar obter o significado de ' $T$ ' por meio de exemplos de coisas que são T.

Geach interpreta (ii) como conseqüência de (i) porque, se não estou na posse de um critério para predicar determinado termo, não posso me assegurar da validade dos casos de T citados. Para Geach temos aqui uma falácia que ele batiza de "falácia socrática". É uma falácia, segundo Geach, porque há muitas coisas que posso conhecer sem que, para tanto, eu precise estar de posse de um critério geral para predicar o termo que se refere ao tópico do meu conhecimento. Há, por exemplo, muitas coisas que posso conhecer sem ter uma definição de conhecimento. Como argumenta também Strawson: “(...) sabemos bastante bem o que é conhecer, muito antes de ouvirmos falar (se isso alguma vez acontecer) de teoria do conhecimento" ${ }^{82}$ A leitura de Geach (comprovada por meio de análises do Eutífron) defende que Sócrates assume, invalidamente, uma tese sobre a prioridade do conhecimento do que significa um termo em relação ao uso do termo em qualquer contexto.

Se Sócrates estivesse entendendo que qualquer menção a casos de conhecimento não pode se dar sem uma definição de conhecimento, certamente ele estaria equivocado. Posso usar o termo "filosofia" em contextos

\footnotetext{
${ }^{81}$ GEACH, P., 'Plato's Euthyphro: An Analysis and Commentary', Monist, 50 (1966), pp. 369-382. (citado a partir de GEACH, P., Logic Matters . Oxford: Blackwell, 1972, 33-4). Para a análise do argumento de Geach ver BURNYEAT, M., 'Examples in Epistemology: Socrates, Theaetetus and G. E. Moore', Philosophy, Vol. 52, №. 202, (1977), pp. 381-398.

${ }^{82}$ Strawson, P. F. Análise e Metafísica. São Paulo: Discurso Editorial, 2002, p. 20.
} 
onde certa familiaridade com 0 mundo acadêmico me garante um conhecimento vago da espécie de coisas que o termo cobre, mas não preciso ter o entendimento dos filósofos profissionais para tal. Teeteto, que é um jovem

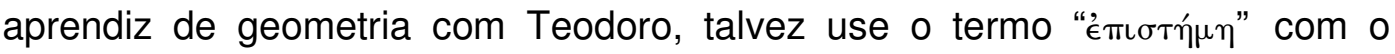
mestre e é provável que nesse uso não lhe seja cobrado uma definição conforme os cânones do $\epsilon^{\prime} \lambda \epsilon \gamma \chi$ os.

Quero supor que há certa plausibilidade no ponto de Sócrates se ele estiver argumentando que um entendimento do referente do nome conhecimento, seja qual for, é fundamental no entendimento do que significa de fato a expressão "o conhecimento do sapateiro" ${ }^{83}$ A consciência da diferença entre um hábito de uso do nome e uma compreensão do referente do nome é freqüentemente citada por Platão para orientar o exame de uma questão. Por exemplo, quando termina a apresentação da Digressão e retoma o exame da doutrina protagoreana, em 177c-d, Sócrates discute duas perspectivas: uma concepção de administração pública, cujos princípios são relativos aos cidadãos - conforme o espírito do protagoreanismo -, e uma

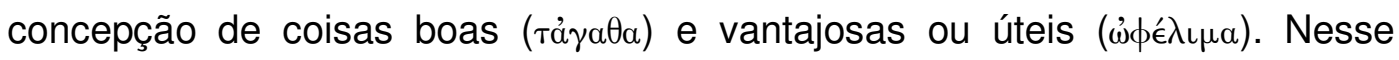
contexto Sócrates diz que a investigação sobre o sentido desta última categoria não deve ser baseada "na palavra" ("丷vopa), mas naquilo que a palavra designa $(\pi \rho \hat{\gamma} \gamma \mu \alpha)$.

O argumento do Teeteto que rejeita as especialidades pode ser a tese de que é necessário um entendimento prévio da definição do referente do termo "conhecimento" para que se possa entender o que é ou não é sugerido na frase "conhecimento do sapateiro" (cf. Teeteto 147b). Mesmo que aceitemos essa tese, ela não implica que o entendimento da essência do conhecimento seja uma condição necessária para seu uso na prática cotidiana e, creio, nada no texto do Teeteto demonstra que Platão queira argumentar isso.

A questão de Sócrates pode ser abordada como uma diferença entre um conhecimento prático e um conhecimento teórico (proposto pelo filósofo):

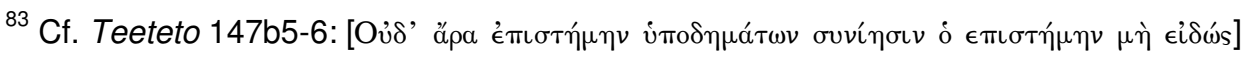


Da mesma forma que possuímos um domínio funcional da gramática de nossa língua nativa, também possuímos um domínio funcional desse equipamento conceitual. Sabemos manejá-lo, usá-lo no pensamento e no discurso. Mas tal como o domínio prático da gramática não implica a habilidade de determinar quais são as regras que observamos sem esforço, do mesmo modo o domínio prático do equipamento conceitual não implica de forma alguma possuir entendimento claro, explícito, dos princípios que governam a utilização do equipamento, possuir a teoria da nossa prática. Assim - concluindo a analogia - do mesmo modo que o gramático, especialmente o gramático moderno de modelos, se esforça em produzir uma análise sistemática da estrutura das regras que seguimos sem esforço ao falar gramaticalmente, também o filósofo se esforça para produzir uma análise sistemática da estrutura conceitual geral cujo domínio tácito e inconsciente é mostrado na prática. ${ }^{84}$

Quando Sócrates faz a pergunta sobre o sentido geral de conhecimento no Teeteto, é um saber análogo ao do gramático que ele deseja. Sócrates não está rejeitando os exemplos enquanto tais, eles os está rejeitando porque a menção às espécies de conhecimentos não acrescenta nada de unitário à investigação, mesmo que haja algo de geral nos casos. A questão que o Teeteto coloca, portanto, é uma questão sobre a possibilidade de uma estrutura do conhecimento enquanto tal. Seria evidentemente implausível defender que o autor do Teeteto identifica a investigação da propriedade (definição) com a propriedade ou com o que ele nomeia ousia, mas sem a primeira não se pode entender a estrutura da última.

\subsection{Separação entre razão e sensação no Fédon}

Talvez o argumento mais clássico sobre o que está na base do entendimento da ousia em Platão seja o texto do Fédon 74b-c. Em Fédon 74bc temos um argumento sobre a distinção entre sensíveis e Formas. Sócrates argumenta uma diferença entre propriedades sensíveis que mantêm co-

\footnotetext{
${ }^{84}$ StRaWSON, 2002, p. 21.
} 
presença de opostos e uma Forma que não mantém essa co-presença. O argumento tem a seguinte estrutura:

1) pedras e paus, sendo iguais, aparecem iguais a alguém e desiguais a

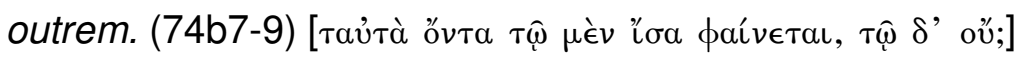

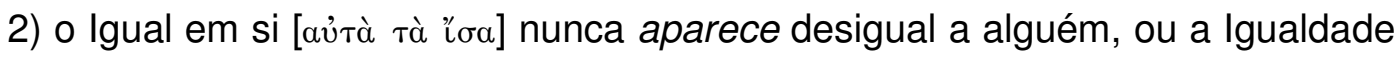
Desigualdade (74c1-3)

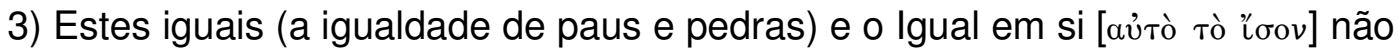

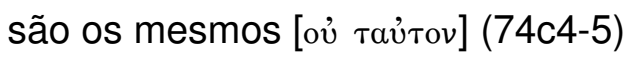

A passagem argumenta que há uma distinção entre a idéia de Igualdade e as "igualdades" atribuídas a pedras e paus, quando alguém os vê como iguais e outra pessoa os vês como desiguais. Irwin interpreta "tō(i) men isa phainetai, tō(i) d'ou" como o fato de algo aparecer no campo visual de alguém enquanto igual (e ser de fato igual) e no campo visual de outra pessoa parecer desigual (e ser de fato desigual). Irwin contesta que phainetai (parecer) tenha um sentido não-verídico na frase de 74b7-10. Se 'parecer' é verídico - e não neutro - então o ponto é que diferentes pessoas consideram estes iguais em diferentes comparações e obtêm diferentes resultados. ${ }^{85}$ Irwin vê um paralelo entre esta passagem e aquele trecho sobre os três dedos em República 523-5. As duas passagens mostram que, se o critério de julgamento é a sensação, o resultado é uma confusão entre o caráter de $\mathrm{F}$ e os $\mathrm{F}$ particulares. Isso nos leva a concluir que o critério da distinção entre Formas e sensíveis é um critério de diferença: $F$ enquanto Forma do Igual é distinta dos predicados atribuídos a pedras e paus, assim como F enquanto Forma da Grandeza e da Pequenez é distinta dos predicados atribuídos a itens grandes ou pequenos, na experiência. O mesmo argumento pode ser defendido para a apreensão da ousia.

Mas como se esse entendimento da unidade de uma ousia se conecta à propriedade essencial do conhecimento que constitui o tema do Teeteto? No Teeteto Platão não se detém para explicar a complexidade desse processo na

\footnotetext{
${ }^{85}$ Cf. IRWIN, T. 'Plato's Heracleiteanism', The Philosophical Quarterly, Vol. 27, No. 106 (1977), $1-13$, aqui p. 9
} 
alma. Como vimos em 184-6, ele está preocupado em mostrar que se trata de uma perspectiva pura em relação aos processos sensíveis. Ele retrabalha o aspecto da unidade das definições no seu conceito de koiná. Tanto o Fédon 74b-c como o Teeteto 184-6 sugerem uma espécie de separação entre razão e sensação na apreensão da ousia e do ser: não há nada de comum, de misturado ou de cooperativo entre o trabalho intelectual da mente e o processo sensível da percepção enquanto tal. Mas isso não significa que razão e sensação não possam ser momentos - distintivos - do mesmo fato que ocorre à alma.

\section{CAPÍTULO IV}

\section{RAZÃO E SENSAÇÃO NA SEGUNDA PARTE DO TEETETO}

\section{1 identidade e predicação: entre o Teeteto e o Sofista.}

O conhecimento é investigado na estrutura do Teeteto por meio de três hipóteses: sensação, opinião verdadeira e opinião verdadeira acompanhada de logos. Trata-se de uma estratégia similar às definições modernas de conhecimento. Essas definições costumam argumentar a seguinte tese:

Um sujeito $N$ conhece uma proposição $p$ no caso (i) $N$ acredita que $\mathrm{p}$, (ii) $\mathrm{p}$ é verdadeiro, e (iii) a crença verdadeira de $\mathrm{N}$ recebe um incremento de outros fatores, como um corpo coerente de evidências que dão suporte, ou procedimentos de formação de crença confiáveis. ${ }^{86}$

Essa tese tripartite parecer representar o esqueleto de todas as teorias sobre o conhecimento disponíveis, o que revela que Platão quis tocar no cerne dos problemas epistemológicos. As epistemologias modernas manifestam,

\footnotetext{
${ }^{86}$ Cf. SAYRE, K. Belief and Knowledge, Rowman \& Littlefied Publishers, 1997, p. 04.
} 
obviamente, divergências quanto ao que deve ser considerado o fator que tornará a opinião verdadeira - ou "belief" - um estado cognitivo genuíno, i.e., um estado de cognição distinto da mera opinião. Mas, de um modo geral, no âmbito das discussões contemporâneas, se crê que a opinião é um estado cognitivo e o conhecimento uma espécie de opinião que exibe um refinamento, uma qualidade da opinião quando o sujeito adquire uma evidência que a justifica. Um contato simples com o Teeteto já é suficiente para se perceber essa estrutura em dois aspectos: nas três partes do diálogo, cada uma representando um componente da moderna concepção de conhecimento (experiência sensível + crença + razão) e, de modo compacto, na terceira definição, onde opinião verdadeira acompanhada de logos (meta logos) tornase uma hipótese de trabalho para Sócrates e Teeteto.

Na segunda parte do Teeteto Platão discute a relação entre a alma e os itens cognoscíveis no âmbito de uma definição que não vê distinção entre opinião e conhecimento. A moderna abordagem de Platão e a literatura do Teeteto, no entanto, exibem uma preocupante divergência quanto ao significado do que Platão está propondo nessa parte do diálogo. As dificuldades se avolumam, principalmente, nos estudos dos argumentos que perfazem a discussão da opinião falsa.

É comum supor que os problemas da segunda parte do Teeteto são resolvidos no Sofista. Argumenta-se, corretamente, que no Teeteto e no Sofista Platão parece estar envolvido com questões ligadas à forma como se deve explicar a relação entre a alma e os objetos conhecidos por ela. Uma destas questões é o problema da falsidade. Platão demonstra no Teeteto 187c-201d e no Sofista - na seção que Moravcsik chama de "ensaio sobre o discurso" (a partir de $259 e)^{87}$, uma percepção apurada da insuficiência das posições que procuram descrever a estrutura do falso, sobretudo das posições que negam sua existência. Em geral as doutrinas gregas assimilam a opinião falsa ao nãoser.

\footnotetext{
${ }^{87}$ Cf. MORAVCSIK, J. Platão e Platonismo: aparência e realidade na ontologia, na epistemologia e na ética. São Paulo, Loyola, 2006.
} 
O Estrangeiro de Eléia, no Sofista, argumenta que a tese de que o erro tem uma conexão com o não-ser é uma tradição antiga, um modo consagrado de se entender a expressão do não-ser na linguagem. Quando explicamos, conforme a tradição de Parmênides, que exprimir o falso é exprimir "o que não é" (mē on) parece se tratar da tese de que o referente do falso, o que corresponde ao que é expresso pela sentença falsa, não existe. Parece que sentenças falsas são um caso de coisas que não permitem o uso de termos como, "ti" (algo) "epi" (sobre) ou "peri" (acerca de, "about"). Se não há um referente que corresponda ao que a sentença falsa expressa, não há um conteúdo, descrição ou, pelo menos, um agrupamento qualquer de aspectos que possam ser identificados por meio dos termos que exprimem o erro.

A estratégia do Estrangerio de Eléia no exame das teses que se oferecem como fundamento dessa explicação é mostrar dois equívocos: (i) há uma confusão no entendimento do que significa a partícula "não" que acompanha o termo "ser" para formar "não-ser". Acredita-se que a conexão da partícula com o verbo gera uma expressão que significa ( $\sigma \eta \mu a i ́ v \in \iota v)$ "nada"; (2) há um equívoco sobre o que significa uma sentença ( $\lambda$ ó $\left.{ }^{\circ}\right)$ ). O Estrangeiro mostra que a conjunção destes dois equívocos não permite o entendimento da natureza do falso, pois impede que se perceba que a verdade ou a falsidade de uma sentença depende da relação entre o que é expresso na sentença e o sujeito da sentença.

Para Owen ${ }^{88}$ a estratégia de argumentação usada no estudo do não-ser não expressa apenas um exame dos problemas ligados à partícula "não" da nominalização "o não-ser", mas põe na discussão também os paradoxos ligados ao próprio ser. Essa estratégia, nomeada por Owen "parity assumption", revela que Platão está, na verdade, recolocando o ser e o não-ser em novos termos. A novidade em questão é o fato que Platão torna evidente, no Sofista, a necessidade de lidarmos com pelo menos dois modos de se "dizer o ser", para emprestar o jargão aristotélico. Platão não está expressando a tese da Metafísica Zeta 1. A idéia aqui é que Platão reconhece apenas uma idéia de

\footnotetext{
${ }^{88}$ Owen, G. E. L., 'Plato on Not-Being', in: Vlastos, G., (ed.) Plato I: A Collection of Critical Essays. Garden City, 1970, 223-267.
} 
ser, mas sugere que há um uso absoluto e um uso relativo de einai nessa idéia. Para que esse rompimento com a forma antiga de explicação do não-ser seja possível, é necessário também rejeitar a tese de que há uma coincidência perfeita entre o ser de x e a expressão de outras características de x. Esse tema surge no Sofista do seguinte modo.

No Sofista 251a-c o Estrangeiro de Eléia discute o pensamento dos

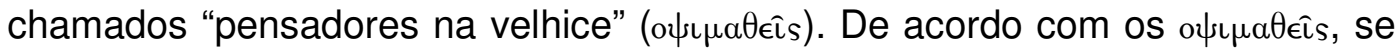
expresso algo como x é y e o referente de y é uma propriedade ou um aspecto que não representa a completude de $x$, não estou exprimindo nada. Neste caso estou cometendo o equívoco de atribuir a $x$ algo que não representa sua natureza. No exemplo do Sofista, se digo "homem é bom", atribuo ao homem uma propriedade que não expressa seu ser. O correto é dizer "o homem é homem" e "o bom é bom". Sobre x só posso dizer que $x$ é $x$. Há diferentes interpretações para o sentido dessa passagem do Sofista. Hamlyn e outros

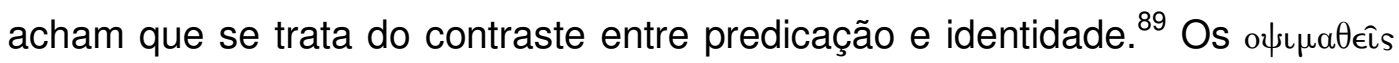
estariam defendendo que predicar é, basicamente, exprimir frases que se enquadram no esquema “...é...”. Aqui a cópula é uma conexão sem muita importância, pois o que realmente conta é que o espaço após o verbo seja preenchido por um termo ou fórmula que expresse exatamente o que está no espaço que precede o verbo.

Embora o argumento possa sugerir uma distinção entre o "é" da identidade e o "é" da predicação, há divergências na literatura acerca da pertinência de vermos ali a consciência platônica dessa distinção. A tese de um "é" da identidade como distinto de um "é" da predicação tornou-se conhecida por meio da obra de G. Frege, sobretudo no artigo "On Concept and Object" ${ }^{90}$ Frege assimila o "é" da identidade ao sinal da equação na matemática. Isso lhe permite argüir que uma sentença de identidade é conversível, ao passo que numa sentença predicativa do tipo $x$ é $y$ a conversibilidade não é o caso.

\footnotetext{
89 HamLYN, D. W., 'The Communion of Forms and the Development of Plato's Logic', The Philosophical Quarterly, Vol. 5, No. 21. (1955), pp. 289-302.

${ }^{90}$ Frege, G., 'On Concept and Object', Mind, New Series, Vol. 60, No. 238 (1951), pp. 168-180.
} 


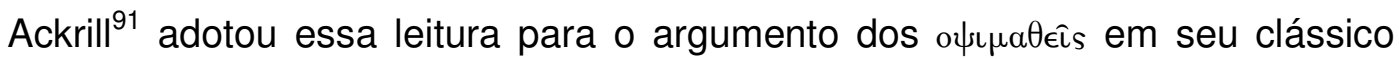
artigo sobre a cópula no Sofista, onde ele se ocupa, basicamente, da refutação da interpretação de Cornford para o trecho da comunhão dos gêneros.

A leitura "fregeana", contudo, é rejeitada por vários intérpretes do Sofista, entre os quais L. Brown, D. Bostock e M. Frede. ${ }^{92} \mathrm{O}$ argumento comum desses comentadores é que não há evidências suficientes que nos permitam ver, em 251a-c e em 254-259 - no argumento da comunhão dos gêneros -, uma antecipação do conceito fregeano. Conforme a leitura de M. Frede, o argumento do Sofista propõe, de fato, um critério para se entender o modo como o ser é usado em dois casos: para expressar aspectos que indicam a idéia de identidade e para exprimir a predicação. Mas Frede argumenta que não se trata de um critério baseado nos "sentidos" do verbo ser ou na identificação da noção de identidade. Para Frede trata-se de dois usos que exibem aspectos distintos de é-esti: (i) $F$ é $F$ em si mesmo ou por si mesmo e (ii) $F$ é $F$ quando está numa relação com outra coisa. Sócrates é branco por estar numa relação com uma cor. A cor branca, por seu lado, é branca em si mesma e não depende de uma relação com Sócrates. A solução de M. Frede "lembra" a argumentação de Aristóteles na Metafísica Zeta. Segundo Frede

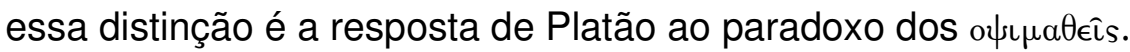

De outro lado, do ponto de vista do emprego do verbo "ser" entre os gregos, de Parmênides a Aristóteles, a tese de que os gregos argumentam a partir da percepção, no verbo einai, de um "é" de identidade distinto do "é" da predicação é uma interpretação contestada nos trabalhos de Charles Kahn. ${ }^{93} \mathrm{~A}$

\footnotetext{
91 ACKRILL, J. L., 'Plato and the Copula: Sophist 251-259', The Journal of Hellenic Studies, Vol. 77, Part 1 (1957), pp. 1-6

92 Cf. Bostock, D. 'Plato on “Is-not” (Sophist 254-9)', OSAP 2, 1984, 89-119; FreDE, M. 'Plato's Sophist on False Statements', in Cambridge Companion to Plato, ed. by R. Kraut, CUP, 1990, 397-424; Brown, L. 'The Sophist on Statements, Predication, and Falsehood', in The Oxford Handbook of Plato, ed. by G. Fine, OUP, 2008, pp. 437-462.

93 Os comentários de Charles Kahn sobre o verbo Ser constituem um monumental estudo sobre as características próprias do emprego de certas estruturas sintáticas nos textos de Parmênides, Platão e Aristóteles para exprimir os temas da filosofia grega. Desde o primeiro artigo, em 1966, até as sucessivas "despedidas" do tema, o trabalho de Kahn continua único e
} 
distinção também é contestada por Michael Lockwood em "On Predicating Proper Names" (1975). Amparando-se neste trabalho, L. Brown adota a tese de que a antecipação de uma distinção fregeana não precisa ser admitida para

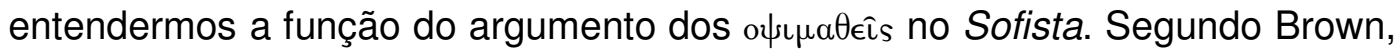
o Estrangeiro de Eléia irá propor como resposta ao argumento uma distinção

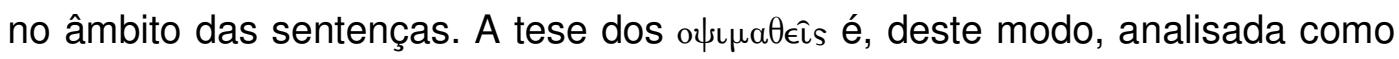
a tese de que não há outra forma de sentença que não seja a sentença de identidade. O Estrangeiro de Eléia proporá, todavia, que sentenças de identidade constituem apenas uma subclasse de sentenças. Esse tipo de sentença não é adequada para a predicação. É preciso examinar a estrutura das sentenças predicativas. A continuação do Sofista a partir daí (a partir de 254) é um argumento que procura defender essa perspectiva como resposta aos paradoxos colocados pelo argumento dos o $\psi \iota \mu a \theta \in \hat{\imath} s$, em 251-c. Não vou me ocupar dos detalhes disso. O que me interessa é essa tese sobre a percepção de uma idéia de ser em si e de ser relacional. O primeiro é a expressão do que define o ser de $x$ essencialmente e o segundo é a expressão de propriedades ou relações.

extremamente influente. A relação original de seus trabalhos sobre o verbo ser é a seguinte: “The Greek Verb 'to be' and the Concept of Being”, Foundations of Language 2 (1966), 245265; "The Thesis of Parmenides" and "More on Parmenides" Review of Metaphysics 22 (196869), 700-724 e 23 (1969-70), 333-340; "The Terminology for Copula and Existence", In Islamic Philosophy and The Classical Tradition: Essays...to Richard Walzer (Cassirer, Oxford, 1972), 141-158); The Verb 'Be' in Ancient Greek (Reidel 1973) = vol 16 Foundations of Language Supplementary Series, ed. J. W. M Verhaar: The Verb 'Be' and its Synonyms, Par 6 (relançado em 2003); "On The Theory of the Verb 'to be'", in Logic and Ontology, ed. Milton K. Munitz (N.Y.U. Press, 1973), pp. 1-20; "Why Existence does not emerge as a distinct concept in Greek Philosophy", Archiv fur Geschichte der Philosophie 58 (1976), 324-334; "Linguistic Relativism and the Greek Project of Ontology", in The Question of Being, ed. Mervyn Sprung (P. S U. Press, 1978), pp. 31-44, republicado em Neue Hefte fur Philosophie, 25 (1978), Heft 15/16, pp. 20-33; "Questions and Categories: Aristotle's doctrine of categories in the light of modern research", in Questions, ed. H. Hiz (Heidel 1978), pp. 227-278; "A Return to The Theory of the Verb 'Be' and the Concept of Being”, in Ancient Philosophy Fall 2004 (2) 381-405. 
Se o tema dessa seção do Sofista é o tema da estrutura das sentenças predicativas, trata-se então da busca de uma explicitação para a estrutura de qualquer discurso declarativo, i.e., do tipo de discurso que não se define, exclusivamente, como a expressão do ser completo de $\mathrm{x}$, mas que se baseia também na articulação de uma descrição de propriedades, de aspectos pertencentes ou das relações de $\mathrm{x}$. Este, quero crer, é o problema que ronda a discussão do falso na segunda parte do Teeteto, pois Platão atribui à equação opinião-verdadeira = conhecimento o ônus da explicação de como e possível à opinião expressar o ser de $\mathrm{x}$, de modo satisfatório, sem cair no não-ser e sem oferecer descrições incompletas.

Não vou argumentar nesta seção, obviamente, que Platão está esclarecido sobre todos os aspectos da predicação, mas vou defender que, na segunda parte, seus argumentos requerem uma leitura a partir de um dos aspectos destacados no Sofista sobre einai: o conhecimento deve ser definido como um discurso que exprime a constituição essencial de $x$ e o estado mental que detém esse saber não pode ser compatível com o desconhecimento de aspectos essenciais de x. Há dois problemas aí: (i) como é possível a copresença, na alma, do conhecimento e não-conhecimento do mesmo item? No Teeteto esse problema antecipa a discussão do segundo problema: (ii) como explicar a diferença entre opinião verdadeira e conhecimento? Platão responde ao segundo problema num argumento curto (200d-201c) após a análise do falso, mas não dá uma solução ao primeiro. Será que ele não sabe como resolvê-lo? Minha hipótese é que Platão está argumentando a necessidade de uma fórmula de conhecimento que conserve o aspecto durativo e efetivo do conhecimento. A comparação com o Sofista é relevante porque qualquer interpretação do tema da predicação, no Sofista, precisa incorporar na análise o aspecto parmenídico da $\mathrm{F}^{\text {dade }}$, interpretado como identidade de $\mathrm{x}$, um traço da ontologia parmenídica que manifesta a idéia de duração do conhecimento. Não creio que o autor dos diálogos tenha abandonado essa idéia em sua visão madura da predicação, no Sofista. É a partir desse aspecto que quero ler os movimentos cruciais do argumento da segunda parte do Teeteto. 


\subsection{O argumento da segunda parte do Teeteto e a tese de Russell}

Uma parte da literatura da segunda seção do Teeteto entende que Platão ainda não tinha formulado a solução para o problema do erro quando escreveu a segunda parte do diálogo. Essa tese carrega consigo a suposição de que o problema do Sofista é uma queixa contra as ontologias - monistas e pluralistas - que não permitem descrições parciais ou relacionais, i.e., asserções que não são asserções de identidade. Supõe-se que o argumento da segunda parte do Teeteto também está marcado por essa tese, pois o argumento se desenvolve no contexto em que opinião verdadeira $=$ conhecimento. Na segunda parte a tese geral é que o estado mental de quem opina com verdade é idêntico ao estado mental de quem conhece. Claro que Platão está argumentando contra essa identificação, mas a questão é saber como ele está concebendo a noção de conhecimento que gera o problema da explicação do erro.

Parte dos intérpretes defende que em 188a-c, onde Platão diz que aquele que conhece $x$ ou (i) conhece $x$ ou (ii) não conhece $x$, ele está exprimindo uma versão "parmenídica" da ontologia criticada no Sofista. Eu concordo que se trata de uma versão parmenídica, mas penso que é a versão virtuosa de Parmênides. Se ela está sendo criticada no Sofista, é um problema com o qual não vou me preocupar. Quero defender que o argumento da segunda parte do Teeteto é platônico e expressa uma condição do conhecimento: o conhecimento de $\mathrm{x}$ precisa ser suficiente para evitar que 0 sujeito adquira opiniões equivocadas sobre $x .{ }^{94}$

A hipótese acima costuma ser evitada, seja porque ela parece muito óbvia para representar a estrutura complexa da segunda parte, seja porque ela parece depender de uma identificação entre conhecimento proposicional e

${ }^{94}$ Minha interpretação da segunda parte do Teeteto deve seu escopo, sobretudo, a três comentários: BENSON, H. 'Why Is There a Discussion of False Belief in the 'Theaetetus?' , Journal of the History of Philosophy, 30:2 (1992), pp. 171-199; CrivelLI, P., 'Plato's Waxen Block', Ideal and Culture of Knowledge in Plato, W. Detel, A. Becker, and P. Scholz (eds.). Stuttgart: Franz Steiner Verlag, 2003, pp. 175-200; SEDLEY, D.The Midwife of Platonism. Oxford: OUP, 2004, pp. 118-152. 
familiaridade, o que revelaria um lapso platônico na percepção do fato que nem todo conhecimento é uma questão de "contato". Platão estaria inconsciente da distinção entre conhecimento "by acquaintance" e conhecimento "by description", tal como Russell a formulou. No que segue mostro que essa distinção pode ser relacionada a Platão de modo equivocado. A boa relação entre Russell e Platão reside em outro aspecto.

A distinção acquaintance-description é proposta pela primeira vez no artigo "Knowledge by Acquaintance and Knowledge by Description" (1910-11). Russell propõe que há dois modos de se conhecer objetos (things, cf. o texto de The Problems of Philosophy). Podemos conhecer por "acquaintance" (conhecimento por familiaridade) ou por "description" (conhecimento proposicional). A tese pode ser interpretada como uma distinção entre um modo de conhecimento que envolve a familiaridade com determinados itens e um modo de conhecimento que envolve acquaintance com proposições sobre os itens. No texto de "Problems" fica claro que se não trata de uma separação entre conhecimento de objetos (físicos) e conhecimento proposicional (proposições), mas de dois modos (complementares) de conhecimento de objetos, um que envolve verdades e outro que se define como familiaridade ou conhecimento baseado no contato, não necessariamente sensível. ${ }^{95}$

Se a distinção russeliana for interpretada do ponto de vista do contraste entre uma relação cognitiva (alma e objeto) análoga à percepção e uma relação cognitiva análoga ao conhecimento de verdades, o bloco de cera (cf. 191a-196c) e o aviário (196d-200c) podem ser interpretados do ponto de vista de uma distinção semelhante a de Russell. No entanto, no Teeteto estas duas passagens não exprimem uma dicotomia entre acquaintance e description (mesmo em Russell não se trata de uma dicotomia). Os dois modos de conhecimento são discutidos no contexto de uma proposição sobre o conhecimento: ou o estado mental de quem conhece garante o sucesso do conhecimento de $\mathrm{x}$ ou o estado mental de quem conhece não é um estado mental equivalente ao conhecimento genuíno.

\footnotetext{
${ }^{95}$ Ver sobretudo as pp. 25 e 32 (primeira e última p. do cap. 05) em Russell, B. The Problems of Philosophy. Oxford: OUP, 2001.
} 
Gail Fine e John McDowell defenderam interpretações divergentes para o significado dessa condição imposta ao conhecimento pelo argumento da segunda parte. Em termos gerais, no entanto, tanto Fine como McDowell defendem que Platão escreve a partir de um princípio análogo ao princípio de Russell para os juízos. Em The Problems of Philosophy, no final do capítulo 05, Russell sugere que "every proposition which we can understand must be composed wholy of constituents with which we are acquainted." 96 Nesse capítulo Russell argumenta que acquaintance e description são dois modos de conhecimento que se complementam, uma tese que não está imune a objeções, mas que pode enfrentá-las de forma convincente, pois se ampara no princípio de que nossos juízos e suposições dificilmente são confiáveis "without knowing what it is that we are judging or supposing about". Na segunda parte do Teeteto a discussão da opinião falsa é inteiramente marcada por um princípio análogo, o qual sugere a impossibilidade de não se conhecer aquilo que se conhece.

Platão, todavia, pode estar se ligando a um aspecto do conhecimento que é uma idéia dos gregos de um modo geral: o conhecimento precisa ser efetivo, sempre verdadeiro, não-relativo. ${ }^{97}$ Aristóteles manifesta essa tese na Ethica Nicomaquéia $\mathrm{VI}, 3$, quando diz que "todos acreditamos que não é

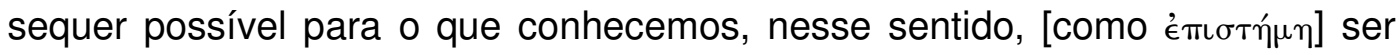

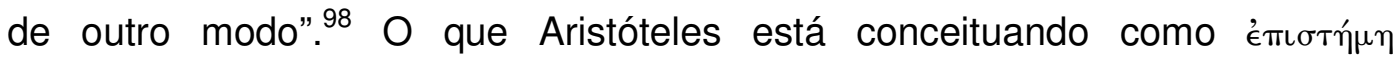
(traduzido por Ross e Irwin como "scientific knowledge"), nessa passagem, envolve duas habilidades principais: dedução de conclusões a partir de premissas e a capacidade de apreender as premissas últimas a partir das quais a dedução deve proceder. ${ }^{99}$ As disciplinas que se organizam conforme esse ideal de conhecimento sistemático são a matemática, a teologia e as áreas

\footnotetext{
${ }^{96}$ Russell, 2001, p. 32.

97 Cf. HiNTIKKA, J., 'Time, Truth, and Knowledge in Ancient Greek Philosophy', American Philosophical Quarterly, vol. 4, 1967, pp. 1-14., aqui p. 07.

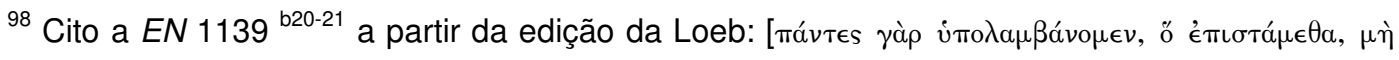

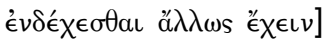

${ }^{99}$ Cf. Bostock, D., Aristotle's Ethics. Oxford: OUP, 2006 [2000], 75-6;
} 
que, para Aristóteles, são cobertas pela física, como biologia e psicologia. Aristóteles entende que o conhecimento obtido nestas áreas busca verdades necessárias. Nós concebemos "necessidade" sob diferentes formas, entre as quais analítica, metafísica e física, mas, quando discute aqui o contraste entre conhecimento teórico e prático, Aristóteles se ampara numa concepção de necessidade que expressa o ideal de um conhecimento do que é universal, o conhecimento em sentido próprio. É esse tipo de conhecimento que está sendo definido no Teeteto. É a crença no tipo de necessidade mencionada por Aristóteles, claramente baseada em Platão, que levará Sócrates aos limites da hipótese da segunda parte, inclusive descartando as analogias do bloco de cera e do aviário.

O aspecto necessário do conhecimento, mencionado acima, aparece no Teeteto da seguinte forma. Na segunda parte do diálogo, no contexto da definição de conhecimento como opinião verdadeira, Sócrates está procurando uma explicação plausível para a co-presença, no estado mental do sujeito que tem a pretensão de conhecimento, do saber e do não-saber do mesmo item (cf. 188a-c). Cinco hipóteses são elaboradas para explicar essa co-presença e todas fracassam pela mesma razão: não oferecem uma explanação satisfatória de como é possível conhecermos coisas concretas (Teeteto, Teodoro) ou proposições (que o número 12 é o resultado de 7+5) e, apesar desse saber, exprimirmos uma opinião falsa. Parte da literatura lembra que o problema é resolvido no Sofista, onde a opinião falsa é explicada como um logos que falha na relação entre, de um lado, a sentença e, de outro, o estado de coisas ou as propriedades vinculadas ao sujeito da sentença.

Vimos que o Sofista discute os problemas do não-ser e propõe uma tese sobre dois sentidos de uso do verbo ser. Contudo, eu penso que há uma condição da opinião falsa sendo explicitada na segunda parte do Teeteto. Essa condição não é mencionada no Sofista. O argumento da segunda parte quer mostrar que a opinião falsa não existe no âmbito da indistinção entre opinião verdadeira e conhecimento, i.e., a opinião falsa só é possível numa definição que tem sucesso na diferenciação destes dois estados cognitivos.

Quanto à similaridade com Russell, ela é sugestiva porque Russell lembra que o discurso é um meio de expressão de idéias que, 
necessariamente, devem ser compreendidas pelo sujeito. Se essa compreensão não é perfeita ou se há uma falha na familiaridade com os constituintes da sentença, nossos juízos podem ser formalmente válidos, mas não serão um caso de conhecimento. Pelo menos para Platão, a linguagem é um meio de expressão do conhecimento, mas o ideal de uma definição de saber deve também considerar o aspecto psicológico que define a relação entre o sujeito e o objeto do conhecimento. O entendimento do que se passa na estrutura da sentença não esgota essa compreensão. ${ }^{100}$

\section{3 análise do argumento da segunda parte}

A segunda parte do Teeteto investiga a hipótese de que o conhecimento situa-se no ato de opinar (doxazein). O argumento de 184b-186e praticamente impôs essa tese quando defendeu que a alma detém a habilidade de produzir juízos por sua própria conta, seja qual for o objeto, sensível ou inteligível. Mas isso é apenas um aspecto do conhecimento. Falta agora examinar a natureza das condições cognitivas que se instalam na alma. Na segunda parte do Teeteto o tema dominante é o aspecto durativo do conhecimento.

Como o problema do falso entra aí? Segundo Heidegger, ${ }^{101}$ o exame do falso parte da seguinte premissa: como a $\delta$ ć $^{102}$ comporta tanto juízos falsos

\footnotetext{
100 Não estou relacionamento "aspecto psicológico" com Russell, mas com Platão. Tento revigorar um comentário de Cornford (1935) que ficou esquecido devido à competência do ataque de R. Robinson ('Forms and Error...' 1950, 3-30) e J. Cooper (1970) a sua interpretação. Cornford destaca que na segunda parte do diálogo a discussão tem um aspecto psicológico que determina a formulação do aspecto lógico. A psicologia do conhecimento em Platão tem a ver com a noção de alma e, como qualquer intérprete reconhece, o conhecimento em Platão é uma propriedade de (i) um discurso e (ii) de um estado mental. A questão é explicar como os dois se combinam para exprimir o que o sujeito conhece.

${ }^{101}$ HEIDEGGER, The Essence of The Truth. New York/London: Continuum, 2002, p. 184.

102 Teeteto, 187a. Estou traduzindo o termo 'Sóga' na segunda parte do Teeteto por 'opinião'. Cabem duas observações importantes. 1) o verbo grego doxazzein permite tomar uma locução substantiva que designa o objeto da doxa. Pode-se afirmar 'doxazein A' que significa "opinar A" ou "crer A". Mas em português (opinar, julgar), assim como no inglês (to believe, to judge), a construção direta é estranha. É mais adequado escrever "opinar que" ou "opinar algo sobre"
} 
como verdadeiros, o entendimento dos segundos exige, antes, um esclarecimento sobre a estrutura dos primeiros, caso queiramos, de fato, justificar a hipótese de que o saber é alethēs doxa. ${ }^{103}$

Como já anunciei, meu propósito é examinar a tese que está na base dessa explicação da opinião falsa: a disjunção saber ou não saber. ${ }^{104}$ Para alguns comentadores, a tese serve ao duplo propósito de, por um lado, criar as condições de possibilidade da definição de conhecimento enquanto opinião verdadeira e, por outro, demonstrar que sob tais condições a hipótese é falsa. Abrem-se, então, dois caminhos de interpretação. Intérpretes como Bostock, McDowell e White julgam que a tese é a responsável pelo fracasso da definição de conhecimento como opinião verdadeira e que o autor do Teeteto se compromete com esse resultado, i.e., ele não sabe como resolver o problema de um conhecimento que convive com o erro. Já para outros, como Fine, Platão está consciente de que a tese é problemática, mas pensa que a melhor maneira de revelar isto é provar que a hipótese da opinião verdadeira como saber está estruturalmente ligada à disjunção epistemológica que a tese propõe. Assim, refutando-se a hipótese, descarta-se a tese.

(em inglês "to believe about", cf. Crivelli, P., 'ALLODOXIA', Archiv Fur Geschichte Der Philosophie 80 (1998), 1-29, aqui p. 3). Isso cria um problema na tradução (ver Burnyeat, 1990, p. 70, n. 4). Em certos casos convém conservar as construções estranhas "Opinar A" ou "crer A" para manter-se fiel ao texto; (2) o outro ponto é que as palavras "opinião", em português, e "belief", em inglês, captam um aspecto importante da discussão na segunda parte. A doxa de que trata o texto é, predominantemente, uma disposição mental (e somente em alguns casos um juízo). Segundo Bostock, a opção por "julgar" ou "juízo", que também são possíveis traduções para doxazein e doxa, tendem a destacar o estado mental de quem julga algo "neste momento aqui", o que não corresponde à continuidade e disposicionalidade da doxa que Platão deseja explorar (Cf. Bostock, 1988, p. 156). Predomina no texto, de fato, uma preocupação com doxa no sentido de um "estado contínuo da mente". Esta é também a posição de Burnyeat, 1990, p. 68.

103 187c3-4.

${ }^{104}$ Essa disjunção é mencionada em várias passagens: 165b2-4, 188a10-b2, 188b4-5, 191b79, 196c1-2, 196c7-d2, 199a7-9, 199c5-6, 199d1-8. 
Afastando-me das duas linhas, sustento que a disjunção "saber ou nãoSaber" permanece intacta ao longo da discussão, servindo, sobretudo, como apoio para a rejeição dos modelos de explicação da opinião falsa. Se estiver correto, poderemos encontrar na segunda parte um elemento que dá unidade à temática do diálogo. Trata-se da proposta de que o saber deve apresentar um aspecto durativo e efetivo. Vou interpretar esse aspecto como uma condição suficiente do saber. Pode ser considerado um aspecto derivado da tese da prioridade da definição, que já discutidos, assim como pode ser também relacionado com o aspecto necessário do entendimento da noção de $F^{\text {dade }}$, tal como é discutida nos diálogos.

Em alguns trechos a disjunção saber ou não-saber expressa a impossibilidade de se conservar na alma o conhecimento e o nãoconhecimento do mesmo item: "é desde logo impossível que quem sabe algo não o saiba, ou que quem não sabe o saiba" (188a10-b1). Em outras passagens o princípio é usado para denunciar uma falha nos modelos de explicação do erro discutidos no diálogo. Um exemplo deste caso está no ataque ao bloco de cera, quando Sócrates questiona o fato de uma pessoa confundir os números 11 e 12: "Pois a pessoa a quem isto acontece crê que o que sabe é diferente daquilo que sabe, caso que estávamos a dizer ser impossível" (196b8-10) .

A discussão mais extensa do princípio está em 188a-c. Trata-se do trecho que abre o exame da opinião falsa por meio da oposição direta, sem intermediários, entre saber e não saber (188a1-2):

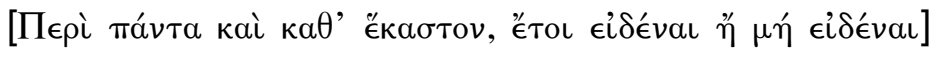

Acerca de tudo e de cada particular, ou sabemos ou não sabemos. ${ }^{105}$

\footnotetext{
105 Por causa dos exemplos usados por Sócrates na explicação da tese (objetos visíveis como Teeteto), CORNFORD julga que a tese está restrita a afirmações de identidade entre objetos que a mente se recorda, excluídos os casos de identificação entre verdades (cf. 1935, p. 113). Mas a primeira parte da sentença em 188a1-2 parece indicar que a tese é ampla. Contra CORNFORD, Williams, C. J. F. ('Referential Opacity and False Belief in the Theaetetus' The Philosophical Quarterly, Vol. 22, No. 89 (1972), pp. 289-302, p. 295ss) argumenta que o modelo da allodoxia indica que o exame platônico não se restringe à afirmações de identidade,
} 
Aqui a tese propõe duas possibilidades para o conhecimento no âmbito da opinião. O conhecimento é uma relação entre a mente e o item cognoscível regrada pela disjunção: deve-se possuir ou não possuir o conhecimento daquilo que está sob exame na alma ou que figura como objeto de um juízo de conhecimento. Chamo o princípio que Platão está expondo em 188a1-2 e em todo o trecho de 188a-c de Princípio Forte do Saber (daqui em diante PF). ${ }^{106}$ Nas análises a seguir examino três aspectos de PF no Teeteto.

\subsection{A interpretação de PF na literatura secundária}

Segundo Bostock, a segunda parte do Teeteto mostra que os instintos platônicos "are, as it were, in the right place, but they are still unarticulated instincts and not yet a clear understanding". Bostock crê que o autor do Teeteto não vê com clareza as implicações de PF. ${ }^{107}$

mas introduz um princípio geral capaz de comportar construções mais complexas: "we may well regard Plato's interest in the judgment that Socrates is Theaetetus as due to its exemplifying the more general formula ' $x$ believes that something which is not $A$ is $A$ ' rather than the more specific ' $x$ believes that A is the same as B" (p. 298). Cf. também Sedley, 2005, pp. 121-125.

106 A idéia de que na segunda parte está em jogo um princípio forte de saber é uma sugestão de OWEN: "for Plato these conditions carried a strong corollary. He seems to have supposed that if I can say what justice is, for example, then I can know everything about it; for he held, correspondingly, that if I am insecure or mistaken or open to counter-argument or counterevidence on these other questions I do not know what justice is. Transfers this conviction to the Theaetetus, and there is a ready explanation for the assumption that if I know something, in the sense of being able to think or speak of it and so have it firmly before my mind, I cannot be mistaken about it and in particular cannot confuse it with anything else." (OWEN, 1986, p. 28). A interpretação de Owen, porem, tem um problema: não há nada no texto que permita ler o princípio como a tese de que se conheço tenho que "know everything about it". O que preciso conhecer é o que está conectado a $x$ de modo essencial. A justiça pode ser associada a muitos outros conceitos na história e quem detém o conhecimento da justiça não poderá, obviamente, conhecer estas relações.

107 Bostock, 1988, p. 197. Segundo Bostock, Platão apresenta uma solução bastante promissora ao problema do falso no bloco de cera e, rapidamente, deixa de lado esta solução para deter-se no aviário. Para Bostock o bloco de cera atrai o instinto platônico porque já contém os elementos da solução do erro: um item pode ser conhecido sob um aspecto 
Mas esse não é o caso da maior parte dos intérpretes. Parte-se da hipótese de que o objetivo da segunda parte é provar a limitação de PF. Para Santos $^{108}$, Platão faz uma crítica ao princípio eleático da separação entre saber e não-saber, o que colocaria o Teeteto na atmosfera que gera o parricídio no Sofista. Para Chappell, a segunda parte mostra que "there is no way for the empiricist to construct contentful belief from contentless sensory awareness alone". ${ }^{109}$ Este comentador entende que o exame do falso é um novo acerto de contas platônico ${ }^{110}$ com o empirismo. Para Cornford, as premissas inseridas na segunda parte não são platônicas: "the whole discussion, however, as we shall see, is limited by certain fundamental premisses, which are not Plato's own". ${ }^{111}$ Já Robinson ${ }^{112}$, comentador que elabora uma minuciosa crítica das análises de Cornford do Teeteto, acha que os argumentos platônicos revelam um modelo de pensamento em que "thinking is sensing without organs". Para Robinson esse modelo impede Platão de ver que o erro e o conhecimento são compatíveis.

(memória) e não sob outro (sensação) e pode "figurar no pensamento" (sensação atual) sob uma perspectiva e não sob outra (impressão). É por isso que Bostock julga que Platão não está criticando PF, mas endossando-o por não conseguir ver com clareza os problemas do princípio. Mas nada nos obriga a aceitar que a alternativa de Bostock é a solução dos problemas discutidos por Platão. Se o estado cognitivo é uma cognição que obtém sucesso no conhecimento de $\mathrm{x}$, certos aspectos essenciais não podem ser ignorados nesse saber. Além do mais, o bloco de cera sugere dois níveis de apreensão, mas Platão está interessado em saber como o conhecimento, definido no bloco de cera como impressão, pode permitir o não-saber, o que indica que se trata de investigar o erro e o conhecimento no mesmo nível de consciência. A idéia de perspectiva não parece interessar a Platão.

${ }^{108}$ SANTOS, J. T., in: PLATÃO, Teeteto. Lisboa: Fundação Calouste Gulbenkian, 2005, pp. 123124.

${ }^{109}$ ChAPPELL, 2005, p. 152.

${ }^{110}$ Para Chappell o primeiro acerto de contas é a refutação da definição de conhecimento como sensação.

${ }^{111}$ CORNFORD, 1935, p. 111.

112 Robinson, R. 'Forms and Error in Plato's Theaetetus', The Philosophical Review, Vol. 59, No. 1. (1950), p. 25. 
Numa linha de argumentação muito semelhante às análises acima, David Barton julga que Platão explora um grupo de "metáforas materialistas" (bloco de cera, aviário, verbos que sugerem "apreender, agarrar") para destacar a fragilidade deste tipo de recurso, sobretudo porque tais analogias procuram descrever a cognição de um modo análogo à apreensão de objetos na mão. ${ }^{113}$ Empirismo, materialismo, eleatismo, "sensação sem órgãos" são modos diferentes de dizer, ora que Platão é vítima de PF, ora que ele o está atacando.

Parece-nos que os intérpretes se baseiam em dois grupos de evidências: 1) argumentos externos ao texto contra a tese de 188a-c e (2) críticas do Teeteto à tese. Vejamos o primeiro caso.

De um ponto de vista externo ao texto, os comentadores lêem o argumento de 188a-c a partir de uma premissa flagrantemente contemporânea: conhecer é compatível com errar. ${ }^{114}$ Pode-se defender que há conhecimento na circunstância em que alguém formula um conteúdo explanatório acerca de um objeto, um saber que não precisa ser uma cognição de tudo o que há para se conhecer. Basta que seja um conhecimento fundado em conteúdos parciais ou fragmentados. Dessa perspectiva, há saber, por exemplo, sobre a matemática quando há domínio de algumas proposições elementares da área, mas seria um erro, nessa linha, afirmar que um matemático "não tem conhecimento" se ainda se bate com certos problemas teóricos sem solução ou se, inadvertidamente, como um erro de calculo.

Essa linha de argumentação não atinge o princípio de Platão. Não se trata da tese de que o conhecimento de $x$ implica o saber, teórico ou empírico, de todos os aspectos de $x$. Trata-se da tese de que conhecimento implica saber que é essencial do item. Além disso, não há evidências de que a tese da compatibilidade entre conhecimento e erro seja óbvia a Platão. É certo que a passagem do bloco de cera (190e5-196c6) mostra que no nível da sensação o autor do Teeteto aceita a compatibilidade, mas isso não quer dizer que PF seja abandonado. Quando analisar o bloco de cera, vou sustentar que o argumento

\footnotetext{
${ }^{113}$ BARTON, D. 'The Theaetetus on how we think', Phronesis, V. XLIV/3, 1999.

114 BURNYEAT segue uma linha de argumentação semelhante, 1990, pp. 72-77, mas não a endossa como linha geral de análise para a segunda parte.
} 
do bloco de cera não ataca o princípio de forma generalizada, mas sua aplicação nos contextos epistêmicos que envolvem a sensação.

\section{5 saber total, acquaintance model e saber efetivo}

Alguns comentadores julgam que 188a-c apresenta uma tese sobre a onisciência do saber. Aqui se afirma que o propósito do autor do diálogo é construir argumentos, baseados em $P F$, que levem à impossibilidade da opinião falsa e provar, com essa estratégia, a inconsistência da hipótese de que a opinião verdadeira é conhecimento. Se isto está correto, é plausível defender que o autor do Teeteto não se compromete com o princípio, mas o utiliza para demonstrar as conseqüências inválidas que o princípio gera quando é assumido como verdadeiro para o conhecimento. Para alguns, uma prova de que o princípio é dialético (e não está sendo assumido) seria o fato de que o bloco de cera e o aviário são modelos de explicação da opinião falsa que admitem gradações e níveis de saber. Se o autor do Teeteto vê algo de positivo nestas analogias, deve ser o fato de que admitem a compatibilidade entre erro e conhecimento. Além disso, essas passagens produzem argumentos que citam PF como princípio a ser superado caso as analogias sejam adequadas.

Julgo essa leitura equivocada pelas razões que procuro explicitar a seguir: (1) em 188a-c o Teeteto não defende uma tese do saber total, mas uma tese do saber efetivo: (2) a discussão do bloco de cera e do aviário não produz argumentos para defender a possibilidade do erro, mas insiste que enquanto essa possibilidade não for eliminada, as analogias não ajudam na discussão. É preciso se valer de um aspecto de "caridade" na interpretação dessas analogias. Platão está no controle da dinâmica das passagens. Quando ele organiza um contra-exemplo, deve-se entender que se trata de uma estratégia transparente: é um argumento do autor do Teeteto contra o argumento desenvolvido nas analogias.

A tese de que a segunda parte do Teeteto é uma demonstração indireta das limitações de $P F$ foi defendida recentemente - e com relativa aceitação entre os comentadores -, por Gail Fine. Fine sustenta que PF (que ela nomeia 
"K") é um princípio inerente à concepção de saber como "acquaintance model". Já vimos que o acquaintace model é uma tese sobre a familiaridade com os termos que estão na consciência do sujeito. Fine argumenta que Platão está se servindo do princípio russelliano para dar apoio à hipótese da segunda definição: o conhecimento é alethēs doxa (cf. 187b). Como há uma rejeição desta hipótese, o "acquaintance model" também seria recusado. ${ }^{115}$ Fine julga que o exame da opinião falsa é um componente essencial desta estratégia de ataque à segunda definição, o que justificaria a longa discussão do tema do erro nesta seção do diálogo.

Há muitos aspectos da análise de Fine que considero atraentes, sobretudo seu esforço para livrar a "allodoxia" dos defeitos dos demais modelos usados para explicar o erro mental. No entanto, Fine comete um equívoco em sua análise ao propor que há um paralelo entre o acquaintance model do Teeteto e o acquaintance model de Russel. Há, em certo sentido, uma similaridade, pois tanto o texto Teeteto como Russell sustentam que algum tipo de contato mental com os termos do juízo - na linguagem russelliana: com os referentes dos termos aos quais se atribui algum significado - é uma condição necessária para a formulação do juízo. ${ }^{116} \mathrm{O}$ erro de Fine é julgar que para Russel o acquaintance model possui a característica da onisciência que estaria também em 188a-c: saber tudo o que há para saber sobre o objeto. ${ }^{117}$ Como mostra Barton ${ }^{118}$, Russel não formula esta conclusão, ou seja, não há em Russell a tese de que "acquaintacce" confere saber total. Deste modo, a relação entre o acquaintance model e a noção de um princípio que confira saber total se torna problemática.

Não sendo um critério de Russell, resta saber se é do Teeteto. Propor que PF é um princípio de onisciência cognitiva implica defender que haveria uma relação cognitiva entre a mente e os objetos caracterizada como saber

\footnotetext{
${ }^{115}$ Cf. FINE, G. "False Belief in the Theaetetus", in: FINE, 2003, p. 213.

${ }^{116}$ Cf. BURNYEAT, 1990, pp. 75-6.

117 "acquaintance, in this sense, confers total knowledge" (2003, p. 216)

${ }^{118}$ Barton, D. 'The Theaetetus on how we think', Phronesis, v. XLIV/3, 1999, pp. 170-173.
} 
absoluto. Mas o que significa "saber absoluto" no contexto da segunda parte? Há duas possibilidades:

(1) "Se conheço A, devo conhecer "tudo sobre A" a ponto de não confundi-lo com B. ${ }^{119}$

(2) Se conheço A, devo ser capaz de distinguir A de B.

A primeira é a tese da onisciência. Parece-me que o que sustenta esta leitura é um conceito de saber absoluto projetado no Teeteto e não uma evidência textual. Não encontramos no texto nenhum sinal desse princípio, apesar de que 0 argumento tem um conceito de conhecimento que não se define de modo específico. É um conceito geral. Mas note-se que a generalidade serve ao propósito da seção: defender a indistinção entre conhecimento e opinião. É uma característica bem conhecida do platonismo, a partir do diálogo Mênon, atribuir à opinião uma recalcitrância, uma prédisposição à mudança, enquanto que o conhecimento deve ser estável. Estabilidade não implica, porém, onisciência.

Em 188a1-2 o princípio forte é apresentado: "acerca de tudo e de cada particular, ou sabemos ou não sabemos". Em seguida, Sócrates descarta os processos intermediários de aprendizado (188a2-4). Em 188a7-8 Sócrates comenta que quem opina, ou opina acerca do que sabe (oî̉ $\in v$ ) ou do que não sabe ( $\mu$ 门 oî $\delta \in v)$. O movimento seguinte apresenta o que julgo ser uma afirmação sobre a impossibilidade de se conhecer e não conhecer simultaneamente o mesmo (тò aủro) item (188a9-b1):

É impossível que quem sabe [o mesmo item] não o saiba ou que quem não sabe 0 saiba. ${ }^{120}$

Não há nada nesta frase que indique onisciência. Trata-se de propor que o conhecimento de um item não pode conviver com o não-conhecimento do mesmo item. Mas como ainda não há uma definição de conhecimento, é temerário assumir que se trata de um "conhecimento absoluto". Em seguida há

\footnotetext{
${ }^{119}$ Cf. SeDLeY, 2004, p. 120

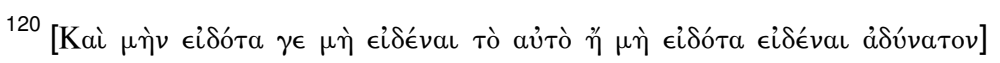


uma breve explicação (188b2-c8) do que poderia acontecer na alma de quem está na condição (contrária à hipótese de 188a9-b1) de saber e não saber o mesmo item. São apresentadas duas possibilidades: 1) quem opina falsamente toma um item que sabe por outro item que sabe, mas na verdade não conhece ambos; 2) ou então considera que as coisas que não sabe são outras, diferentes destas de que não tem conhecimento. Sócrates propõe um exemplo: quem não conhece Teeteto e Sócrates, poderia pensar que Sócrates é Teeteto e Teeteto é Sócrates, caso que se revela impossível. Este exemplo instancia o que está afirmado em 188a9-b1: é impossível, simultaneamente, saber e não saber o mesmo item. Daí a impossibilidade da opinião falsa.

Segundo McDowell, 188b8-c1 propõe que: "if one is to have something in one's judgement, then one must know that thing" ${ }^{\text {"121 }}$. Para McDowell todo 0 trecho de 188a-c tem por base a premissa platônica: "se um item figura em meu juízo, devo conhecê-lo". Trata-se da interpretação de PF em 188a-c: se pronuncio (discursivamente ou não) uma sentença sobre $x$ que tem a pretensão de conhecimento, tenho que ter um contato mental prévio com $\mathrm{x}$. Essa é a conexão entre o argumento de 188a-c e Russell, conforme McDowell defende. É preciso, porém, esclarecer essa condição.

Sedley sugere a seguinte via de análise. No platonismo há dois critérios de conhecimento que criam as condições de possibilidade da seguinte tese: (1) Se conheço $A$, devo ser capaz de distinguir $A$ de $B$. O primeiro critério é uma regra de conversibilidade entre "conhecer x" e "conhecer o que é x". O segundo é uma regra de exclusividade dos itens de que se tem conhecimento, exigência proposta na terceira parte do diálogo (209c5-10). Examinemos o primeiro critério. Em 147b2-7 Sócrates pergunta:

\footnotetext{
${ }^{121}$ Cf. MCDoweLL, 1973, p. 194-198, 213; Identity Mistakes: Plato and the Logical Atomists', p. 385, in: FINE, Plato 1: Metaphysics and Epistemology (ed. Gail Fine), OUP, 1999; BURNYEAT, 1990 , p. 74.
} 
Crês que alguém tem o entendimento do nome de qualquer coisa, quando não sabe o que a coisa é? - De nenhum modo. - Então a pessoa que não sabe o que é conhecimento não entende o conhecimento dos sapatos. ${ }^{122}$

Nesta passagem, cujo contexto já examinamos anteriormente, Sócrates parte da premissa de que o não entendimento do sentido do termo "conhecimento" impede que alguém compreenda o que está implícito na a expressão "conhecimento dos sapatos" (cf. 147b5-6). O que está em jogo na passagem é uma tese sobre a prioridade de um conhecimento essencial sobre o termo "conhecimento" para que se possa entender corretamente a sentença "conhecimento dos sapatos" no âmbito do "conhecimento geral". A prioridade da definição revela o vínculo entre "conhecer x" e "conhecer o que é x". ${ }^{123}$ Se relacionarmos essa convergência entre o conhecimento de $x$ e conhecer o que é $x$ à passagem de 188a-c, teremos um critério para a identificação ou nãoidentificação entre $A$ e $B$, conforme o seguinte princípio:

(1a) se conheço $A$, devo ser capaz de definir $A$ de forma a não confundir $A$ e $B$.

À luz de 147b2-7, não precisamos de um conceito de saber total ou absoluto para entender 188a-c. Não se trata de saber tudo o que há para saber sobre $A$, mas de ter trato mental com um conjunto de aspectos definicionais de A que me permita distinguir $A$ de $B$, se for o caso, ou identificar $A$ e $B$, se for 0 caso. Em 188a-c Sócrates diz que se não conheço nem Sócrates e nem Teeteto, é impossível afirmar a identidade de ambos. Pelo critério de conversibilidade, se conheço Teeteto, então tenho acesso mental a certos traços definicionais de Teeteto, o que é suficiente para que o conhecimento que tenho de Teeteto me permita não confundi-lo com Sócrates. PF pode ser

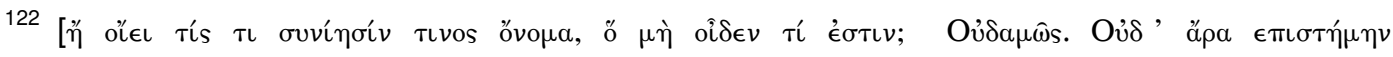

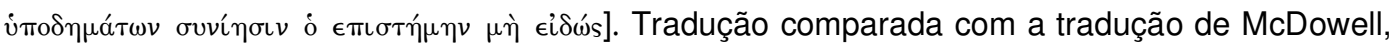
1973.

${ }^{123}$ A conversibilidade é notada também por MCDoweLl, 1973, pp. 115-16, 192-93, 195, e FINE, "knowledge and Logos in the Theaetetus" in: FINE, G. Plato on Knowledge and Forms, Oxford, Clarendon Press, 2003, p. 225.
} 
interpretado como princípio do saber efetivo. Ele é suficiente para a identificação ou não identificação do item conhecido.

O segundo critério (regra de exclusividade) proposto por Sedley está na passagem de 209c5-10:

Creio, contudo, que em mim não se formará uma opinião de Teeteto, antes que este achatamento, como uma certa recordação que se diferencia de outro que vi, assente e fique estampado em mim (...) e se amanhã me encontrar contigo, [este achatamento] há de fazer-me recordar e opinar coisas corretas sobre ti. ${ }^{124}$

Essa passagem revela que Platão tem em mente uma concepção de opinião verdadeira que trabalha os itens de conhecimento do ponto de vista de seus aspectos exclusivos. No contexto da terceira definição, a passagem questiona a tese de que o acréscimo de um logos, definido como marca exclusiva ( $\sigma \eta \mu \hat{\epsilon} \iota o v)$, tornaria a opinião verdadeira um conhecimento. Sócrates argumenta que a opinião verdadeira já deve conter uma apreensão dos aspectos característicos de cada objeto que está sob consideração na alma. A percepção de Teeteto é um exemplo: para que se possa opinar corretamente que o indivíduo que minha percepção capta à distância é Teeteto e não Teodoro, devo reconhecer os traços que pertencem exclusivamente a Teeteto.

O critério da exclusividade e o critério da conversibilidade entre 'conhecer x' e 'conhecer o que é' (prioridade da definição) nos levam ao núcleo da tese de 188a-c: é impossível conhecer e não conhecer um item.

\subsection{Críticas a PF}

A defesa de 188a-c sob a perspectiva do platonismo não elimina todas as evidências de que o princípio está sob ataque. Aqui entra em jogo o que se supõe ser uma crítica explícita a PF. Após o descarte da allodoxia, em 189b-

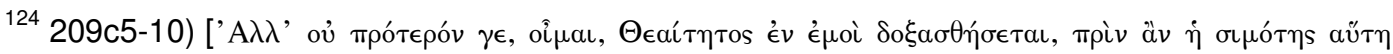

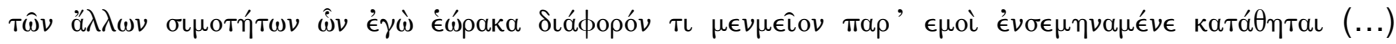

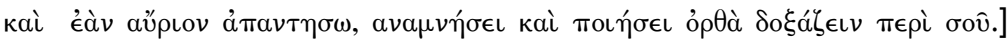


190e, Sócrates e Teeteto dispensam o princípio forte para assumir uma via de argumentação em que o erro é possível:

Digo-te que não chegamos a um acordo correto quando concordamos que é impossível estar em falsidade, ao opinar que o que alguém sabe são as coisas que não sabe. Pelo contrário, é de algum modo possível. (191a8-b1)

Esse recuo em relação ao princípio forte se justifica porque Sócrates pretende introduzir um modelo de explicação do erro em que é possível conhecer um objeto e errar a consideração do objeto no momento da sensação. É o que ocorre no bloco de cera, analogia em que a alma é

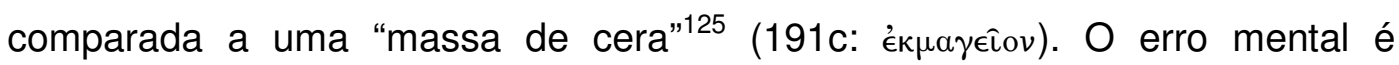
caracterizado como "desajuste" entre a marca do item impresso na massa de cera (alma) e a visão atual do item:

Pois bem, supõe, tendo em vista o argumento, que nas nossas almas há uma espécie de bloco de cera que recebe as impressões; maior em uns, menor em outros; em alguns de cera mais pura, noutros mais suja; nuns de cera mais dura e noutros mais líquida, mas em alguns com consistência apropriada. (191c8-d1) $)^{126}$

As imagens impressas na massa de cera não são itens originais. Elas são "produtos do original" ${ }^{127}$, uma espécie de "dublê" da imagem original. Mas como Platão concebe esta conexão entre a sensação atual e a memória impressa? Segundo Crivelli, não se trata de uma produção sob a circunstância em que a memória impressa de x é "produzida" por uma sensação que, por sua vez, é produzida por $x$. Se fosse este o caso, haveria uma relação causal entre o $\mathrm{x}$ original e a memória de $\mathrm{x}$ impressa na massa de cera. Embora plausível, a relação causal supõe que Platão está fazendo uma descrição empirista: o que

\footnotetext{
${ }^{125}$ Segundo Heidegger (2002, p. 209,) o modelo de cera é uma 'massa' na qual algo é impresso. Crivelli (2003) traduz por "bloco de cera" ("waxen block"). Para Crivelli Platão tem em mente blocos nos quais se deixam marcas.

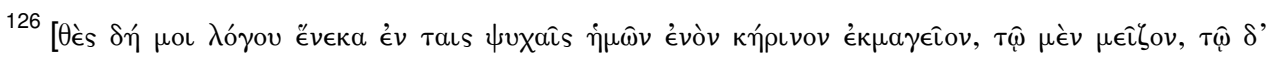

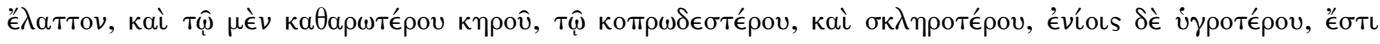
$\delta$ ' oîs $\mu \in \tau \rho i ́ \omega s$ '́x $\chi 0 \nu \tau o s]$.

${ }^{127}$ Cf. BenARDETE, S. Plato's Theaetetus: part I of The Being of the Beautiful. Chicago and London: UCP, p. 155.
} 
há na mente é causado pela percepção (numérica) de x. Segundo Crivelli Platão vê o processo de outro modo. A memória de $\mathrm{x}$ reproduz aspectos de $\mathrm{x}$ porque é uma memória impressa que "se encaixa" ${ }^{128}$ com o original. Esse aspecto é importante para entendermos o sentido preciso da analogia. A memória de $\mathrm{x}$ reproduz traços do original que lhe pertencem de forma exclusiva. Crivelli cita 209c5-10 (cf. acima) e explica o ponto da seguinte maneira:

(...) the main use of memory imprints is within (successful or unsuccessful) identifications (see 193c4-5), as when Socrates (successful or unsuccessful) identifies Theatetus by matching his memory imprint of Theodorus with his vision of Theaetetus. In such identifications one uses the perception of the object which one is trying to identify in order to discover whether the object has certain characteristics which are recorded in one's memory. Since the natural way of expressing such an identification is to utter a sentence like "This is Theatetus", there seems to be some reason to conclude that the name "Theaetetus" refers to the man Theaetetus in so far as the characteristics recorded by the memory imprint belong exclusively to him."129

A idéia aqui é que Platão concebe o argumento do bloco de cera sob a forma de um encaixe de imagens mentais com imagens atuais da percepção. O conhecimento, definido no bloco de cera como impressão, não é resultado de sucessivas experiências com o item na experiência. $O$ bloco de cera não especifica a origem dessas impressões. O bloco de cera é uma analogia para retratar a relação entre o conhecimento e a percepção de itens que se referem ao que está na alma. Por isso Crivelli destaca que no bloco de cera o conceito operativo é o de comparação entre o item na alma e o item experienciado na percepção.

Mas por que o bloco de cera é visto como crítica a PF? Segundo McDowell, o bloco de cera rompe com a tese de 188a-c: "if one is to have something in one's judgement, then one must know that thing" ${ }^{\text {"130 }}$, pois a lista de

\footnotetext{
${ }^{128}$ É também a forma com BURNYEAT lê o bloco de cera, cf. 1990, pp. 91-105.

${ }^{129}$ Crivelli, 2003, p. 188.

${ }^{130}$ MCDOWELL, 1973, p. 196
} 
casos em 191e9-192 $d^{131}$ apresenta situações em que a sensação de algo, sem o conhecimento correspondente, é suficiente para que o objeto esteja sob consideração na alma, quebrando assim a tese da necessidade do conhecimento do item. Para McDowell, se em 188a-c a tese do contato estava em jogo para marcar a necessidade de que a alma tenha uma apreensão prévia do item para formar o juízo, aqui se trabalha com a hipótese de que existem duas formas distintas de contato mental com um item: a sensação e o conhecimento. McDowell crê que 188a-c propõe o modelo de acquaintance russelliano, em que conhecimento é trato mental, uma familiaridade com o item (cf. o verbo connaître) sob a forma de contato. Deste ponto de vista, o bloco de cera estaria mostrando que há compatibilidade entre conhecer x e errar acerca de x, contrário a 188a-c.

Mas proponho ler o argumento de outro modo. Minha hipótese é que 188a-c propõe a impossibilidade de se conhecer e não conhecer o mesmo item sob o mesmo modo de acesso epistêmico (PF), tese que chamei de princípio forte ou princípio do saber efetivo. Sob esse ponto de vista, na medida em que o bloco de cera se oferece como contra-exemplo à tese, deve-se esperar que essa analogia mostre que é possível apreender incorretamente um item sob o

\footnotetext{
131 MCDOWELL, 1973, pp. 210-211, classifica os casos em que a opinião falsa é impossível (cf. 191e9-192d2). Todos os casos se enquadram no esquema "algo" (por exemplo 'a') é outra coisa (por exemplo 'b'):

(1) Casos em que a opinião falsa é impossível (192a1-5)

(a) casos em que somente o conhecimento está envolvido (192a1-7):

(i) $a$ conhecido, $b$ conhecido

(ii) $a$ conhecido, $b$ não-conhecido

(iii) a não-conhecido, $b$ não-conhecido

(iv) a não-conhecido, $b$ conhecido

(b) casos que envolvem somente percepção (192a7-b2):

(i) a percebido, $b$ percebido

(ii) $a$ percebido, $b$ não-percebido

(iii) a não-percebido, $b$ não-percebido

(iv) a não-percebido, $b$ percebido

(c) casos em que percepção e conhecimento estão envolvidos (192b2-c5):

(i) a conhecido e percebido (percepção combinada com impressão), $b$ do mesmo modo.

(ii) a conhecido e percebido (percepção combinada com impressão), $b$ não-conhecido

(iii) a conhecido e percebido (percepção combinada com impressão), $b$ percebido

(iv) a não-conhecido e não-percebido, $b$ do mesmo modo

(v) a não-conhecido e não-percebido, $b$ não-conhecido

(vi) a conhecido e não-percebido, $b$ não-percebido

(2) casos em que a opinião falsa é possível

(i) a conhecido, b conhecido e percebido

(ii) a conhecido, $b$ não-conhecido, mas percebido

(iii) $a$ conhecido e percebido, $b$ do mesmo modo.
} 
mesmo modo de acesso epistêmico. Ao falar de "modo de acesso epistêmico" estou me servindo da análise de Burnyeat: "Plato speaks of perceiving $X$ and Knowing $Y$, distinguishing two epistemic routes from mind to thing". ${ }^{132}$ Com efeito, para que haja refutação de PF, como quer McDowell, o bloco de cera deve mostrar em que condições é possível tomar o conhecimento de $X$ como conhecimento de $Y$ no mesmo modo de acesso epistêmico, isto é, do ponto de vista do conhecimento de $\mathrm{X}$. Na seqüência, demonstro que o argumento não quer provar essa possibilidade.

Para esclarecer meu ponto, gostaria de comentar alguns detalhes da argumentação de Sócrates na parte do texto propriamente explicativa, isto é, após o inventário de casos em a opinião falsa é ou não possível. ${ }^{133}$ Nesta seção, a partir de 192e, temos a seguinte premissa:

(1) é possível perceber e não perceber um item conhecido (192e)

(1a) Exemplo: Sócrates conhece Teeteto e Teodoro. Em alguns casos Sócrates os vê, em outros não possui sensação alguma de ambos. No entanto, o conhecimento acerca dos dois permanece na alma (cf. 192d).

Tanto a premissa como o exemplo são afirmados após a lista de casos em que a opinião falsa se revelou impossível (192a-d), o que significa que Sócrates deseja agora efetivamente mostrar a fonte do erro. Examinemos a tese da premissa em 192e: a sensação pode ou não estar envolvida nos itens sobre os quais há conhecimento. Essa premissa é importante, pois revela que se trata agora de mostrar que há duas possibilidades para um item que é conhecido: ser ou não ser percebido. Quando a sensação não está envolvida,

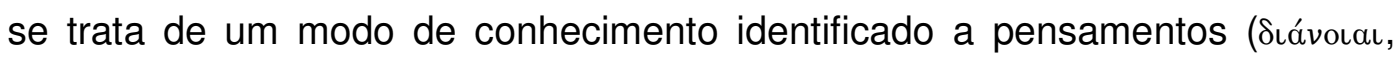
195d1, d2). É o ato de referir a um objeto apenas pela memória impressa, sem a percepção. ${ }^{134}$ Platão usa a expressão "possuir no pensamento" para

\footnotetext{
132 Burnyeat, 1990, p. 93. CrivelLi explora bastante essa possibilidade do argumento em CrivelLi, 2003.

${ }^{133}$ Os 14 casos lista em 191e9-192d2.

${ }^{134}$ Cf. CRIVELLI, 2003, p. 187.
} 


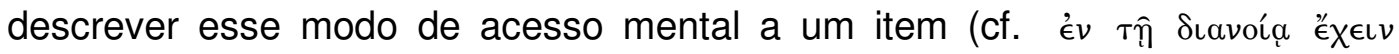

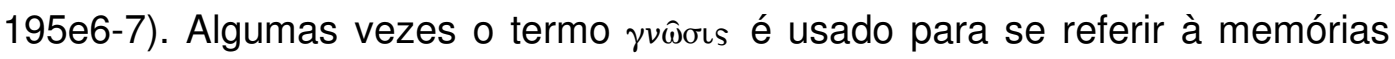
impressas (193d7; e1, e3). A relação entre os dois modos, percepção e pensamento, não é causal, como argumentamos acima. As memórias impressas não são produzidas por "uma impressão", mas são conhecimentos alojados na alma. Interpretar de modo causal é ignorar o fato que o bloco de cera é uma analogia para a alma (cf.191c).

O comentário de Sócrates sobre $1 a$ (ver acima) é o seguinte. Se Sócrates conhece Teeteto e não conhece Teodoro, não tendo dos dois nenhuma sensação atual, não pode crer que o que conhece é o que não conhece (cf. 193a). Essa afirmação é uma defesa explícita do princípio forte que expomos acima. $\mathrm{O}$ argumento seguinte de Sócrates é uma variação desta tese. Sócrates argumenta que sem conhecer e sem perceber a ambos (Teeteto e Teodoro), não se pode crer que o que não se conhece é algum outro item que também não se conhece. Aqui se observa que percepção e conhecimento são dois modos distintos ${ }^{135}$ de acesso a um item. Crivelli nota que há um claro contraste entre sensação e sonhecimento no bloco de cera: "this constrast presupposes that perception of an object is not knowledge of it". ${ }^{136}$

Isso significa que o bloco de cera não está propondo que o conhecimento "envolve a sensação", permitindo ao saber uma mistura com a percepção, como nas epistemologias empiristas. Embora o argumento esteja "comparando" as possibilidades de "cruzamento" entre os dois níveis, nota-se que a comparação é "empírica" e não "teórica". A comparação é feita sob a condição empírica em que um item conhecido "mentalmente", caso da impressão na alma de Teeteto, é relacionado ao contato direto com um dado de percepção (Teeteto). Note-se que esse exemplo parece ser típico no texto: 192a1-4, c9-d1, d3-5, 192e8-193a11, 193b10. Em todas essas passagens 0 que se tem é a comparação entre um item conhecido pela alma e um item percebido, sobretudo na passagem 192d3-5, onde Sócrates compara o

\footnotetext{
${ }^{135}$ Cf. BuRnYeAt, 1990, p. 92; Bostock, 1988, p. 177.

${ }^{136}$ CrivelLi, 2003, p. 180.
} 
conhecimento de Teodoro e Teeteto na alma com a percepção de ambos. Mas essa comparação não implica uma "fusão" entre conhecimento e sensação. $\mathrm{Na}$ seção seguinte isto ficará mais evidente quando Sócrates mostrar a gênese do erro no bloco de cera.

O erro ocorre no seguinte caso: Sócrates conhece Teeteto e Teodoro e tem no bloco de cera os sinais dos dois, mas não vê os dois de forma adequada. A idéia é que a percepção não retrata adequadamente Teeteto e Teodoro:

A opinião falsa se produz quando alguém conhece e vê ambos, ou tem alguma outra percepção de ambos, mas não tem os sinais de cada um na sua própria percepção, e, como um mau arqueiro, se desvia do alvo. ${ }^{137}$

Há um esforço para se identificar o tipo de item presente na percepção e para "combinar" esta sensação com a marca existente na alma. O erro ocorre porque este esforço não produz o resultado esperado devido à falta de rigor da percepção atual. Note-se que a tese é que o erro ocorre em casos em que há conhecimento e percepção do mesmo item. Em 194b Sócrates diz que, acerca de casos em que não há conhecimento ou não há percepção, não se pode produzir opiniões falsas. A estrutura destas passagens não está questionando $P F$, pois não mostra que é possível "conhecer e não conhecer o mesmo item", mas indicando que o erro ocorre no momento da percepção. Isso quer dizer que não é o conhecimento, interpretado na passagem como "marca" ( que "causa" o erro, mas a sensação atual.

A passagem seguinte é crucial para o argumento. Trata-se do momento que Sócrates imagina um questionador que irá perturbar sua aparente satisfação com a solução proposta. A solução, lembremos, é a tese de que o erro é um desajuste entre sensação e memória impressa na alma. Como argumenta o questionador imaginário:

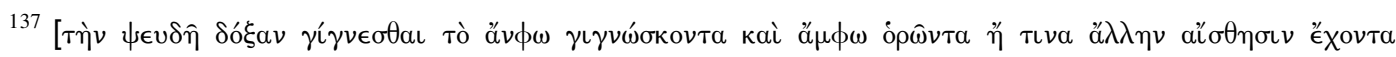

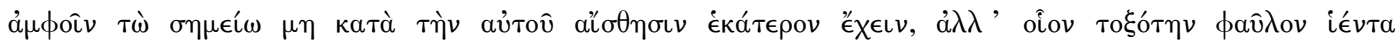

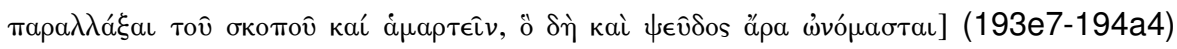


Sócrates, não descobriste que a opinião falsa não se dá no domínio das percepções, umas com as outras, nem no do pensamento, mas no da relação da percepção com o pensamento... ${ }^{138}$

Como acertadamente percebe Campbell, comentando a passagem acima, "If mistake arises upon the wrong union of sensation and thought, thought cannot be mistaken when unaccompanied by sensation." ${ }^{139}$ Ao retirar da passagem a mesma conseqüência que Campbell, Burnyeat não consegue evitar seu desapontamento, pois o bloco de cera parece afastar-se da crítica a PF para explorar a fonte do erro na sensação. Para Burnyeat o bloco de cera:

(...) does not suggest that a correct understanding of what is involved in thinking of $X$ will show it to be compatible with misidentifying $X$, but rather that thinking of $X$ (as $X)$ is compatible with misidentifying $X$ in circumstances such that the thought of $X$ (as $X$ ) plays no part in bringing $X$ before the mind to be mistaken for $\mathrm{Y}^{140}$

A análise de Burnyeat toca no ponto crucial: o pensamento de $x$ (enquanto x) não tem parte no ato mental que gera o equívoco entre $x$ e y. Infere-se a partir desta análise que o erro não é compatível com o conhecimento no sentido formal, i.e., do ponto de vista do que deve ser a definição de conhecimento: conhecer um item é ter dele uma definição acerca de seus aspectos exclusivos. Burnyeat expressa isso ao dizer que o erro ocorre nas situações em que o pensamento de X "como X" não exerce função alguma, pois $X$ está aí sob efeito da percepção e não do pensamento (impressão). É a sensação que "bringing $X$ before the mind" propicia o erro. Segundo Burnyeat, o bloco de cera "assures us only that perception by itself is an independent way

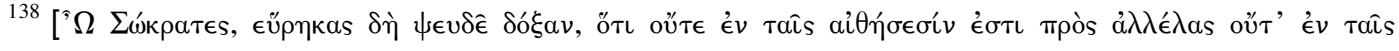

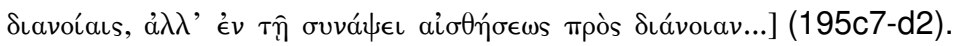

139 CAmpBeLL, L. The Theaetetus of Plato. Revisão do texto grego e notas em inglês por Lewis Campbell. Oxford: Clarendon Press, 1980 [1883], 193.

${ }^{140}$ BurnyeAt, 1990, p. 99.
} 
to 'get hold of something with the soul'; it offers no such guarantee for perception aided by thought". ${ }^{141}$

Creio que a análise acima mostra porque o objetivo do bloco de cera não é - como um ponto de vista moderno poderia supor - explicar que há diferentes modos de conhecimento e que, portanto, deve-se recusar a análise do saber sob a perspectiva de um único modo (PF). O objetivo do bloco de cera é, antes de tudo, definir apenas dois modos de acesso epistêmico: percepção e conhecimento (cf. 192e). Em segundo lugar, mostrar que há possibilidade de erro na conjunção, empírica, dos dois modos ou no interior de um deles (sensação atual). Mas o erro não ocorre quando o pensamento está sendo plenamente exercido, o que, conforme 184-6, significa apartar-se da sensação.

Uma vez definida a estrutura do bloco de cera, Sócrates e Teeteto se envolvem no criticismo da analogia. Aqui temos dois pontos importantes: (1) a crítica mostra que o modelo tem uma aplicação limitada; (2) como o bloco de cera sugere que um item conhecido (impressão) não exerce papel na sensação que comete um erro sobre o mesmo item, tem-se então uma situação em que o sujeito tem o saber, mas este permanece inerte em sua alma.

No aviário, analogia criada para explicar um erro cuja estrutura não pôde ser explicada pelo modelo de cera, esse problema da inércia do saber ganha destaque. Sócrates argumenta que o modelo de cera não é adequado para explicar o erro de quem soma ' $5+7$ ' e chega ao resultado ' 11 ', ao invés de '12'. Segundo Sócrates este erro implica uma identificação entre dois itens nos limites do pensamento. Há dois momentos distintos no processo. Primeiro, adquiro o conhecimento do 11 e do 12 e os coloco em minha alma-gaiola. Depois, uma necessidade de fazer um cálculo (uso) me faz ativar o conhecimento do 11. Na busca pelo 12 tomo o 11 como resultado da soma.

Já se observou muitas vezes, na literatura, que o que Platão expõe aqui é a distinção entre potencialidade e atualidade do conhecimento, mais tarde

141 Idem, p. 93. 
desenvolvida por Aristóteles. ${ }^{142}$ Mas a questão relevante é: por que o erro não é explicado a partir dessa distinção, ou seja, por qual razão o aviário se torna, na descrição de Sócrates, um modelo incapaz de explicar a opinião falsa? Gostaria de examinar o criticismo do aviário por meio da análise da seguinte passagem:

Em primeiro lugar, refiro-me à dificuldade de aquele que tem o saber ignorar aquilo que sabe, não devido à sua ignorância, mas ao seu próprio saber; segundo, opinar que o que sabe é algo diferente [heteron], e isto se identifica ao que sabe ... (199d1-3) $)^{143}$

A passagem chama a atenção para dois problemas notados na hipótese do aviário: (1) no aviário o erro é causado por um conhecimento; (2) o sujeito "opina" algo na condição de "heteron", de algo distinto, outra coisa. Nota-se que a crítica de Sócrates não leva em conta o principal aspecto do aviário: a distinção entre conhecimento potencial e conhecimento ativo. Sócrates poderia afirmar que o erro ocorreu porque o conhecimento potencial do número 11 , 0 saber do que ele é essencialmente, não foi ativado. Mas Sócrates não utiliza essa distinção na passagem acima. Ele provavelmente está dizendo que a distinção não ajuda a entender como o conhecimento pode ser a "causa" do erro. Por isso, a solução do aviário, se acordo com Sócrates, não é uma boa solução. A distinção entre conhecimento potencial e conhecimento ativo não é suficiente para introduzir o conceito de erro em PF. Se o conhecimento ativo não se vale de um estado cognitivo que lhe dá fundamento, continua o problema de um saber que não tem efetividade. Penso que o autor do Teeteto está consciente disso e, aparentemente, deseja que essa conseqüência seja explícita no aviário.

\subsection{Solução do problema da opinião falsa}

A passagem acima termina sugerindo que a opinião falsa é "outra coisa" (heteron). Há evidências no Teeteto de que essa hipótese é um tipo de

\footnotetext{
${ }^{142}$ Ver SEDLEY, 2004, p. 140.

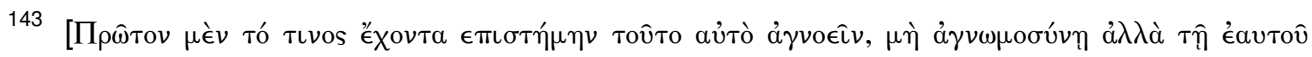
є̇
} 
estrutura platônica da opinião falsa que o texto se serve aqui e ali, embora nunca a defenda explicitamente. Neste sentido, pode-se interpretar as três últimas explicações da opinião falsa como instâncias da tese. Assim, na allodoxia a alma lida com dois itens e os confunde no pensamento, no bloco de cera a alma confunde o item conhecido com o item da percepção e no aviário a alma busca um item e, inadvertidamente, se depara com outro.

A estrutura dessa explicação exprime a hipótese de que o erro mental é uma situação em que se toma um item na condição de algo distinto dele. Essa tese não só está isenta de refutação no diálogo, como também é retomada no

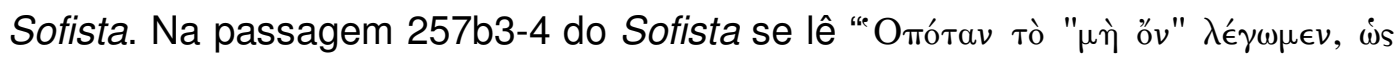

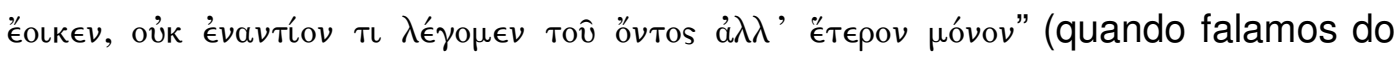
não-ser, ao que parece, não falamos de algo contrário ao ser, mas apenas de algo diferente). O Sofista produz uma análise satisfatória do problema, mas parte da mesma distinção feita no Teeteto: o não-ser ou o erro não é algo

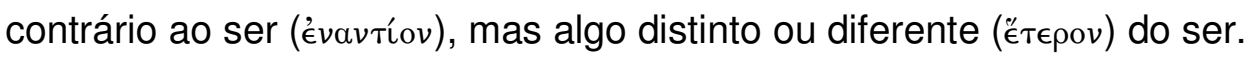

\section{CAPÍTULO V}

\section{RAZÃo E SENSAÇÃO NA TERCEIRA PARTE DO TEETETO}

No que segue apresento alguns resultados do meu exame da noção de razão (logos) e percepção na teoria do sonho. Procuro identificar as teses que o autor da teoria do sonho defende sobre as condições cognitivas dos elementos. Meu objetivo é interpretar de forma satisfatória uma condição específica citada em 202b7: que os elementos são perceptíveis. Não há uma informação precisa sobre o sentido dessa perceptibilidade no texto, embora na literatura do diálogo alguns comentadores tenham defendido que se trata de uma noção de sensação no sentido de impressão pura, tal como Platão 
apresenta no argumento de 184-6. Meu trabalho procura demonstrar as deficiências dessa leitura.

\subsection{Logos e composto na teoria do sonho.}

$\mathrm{Na}$ tradução de Levett a teoria do sonho se desenvolve do seguinte modo (201d8-202c6):

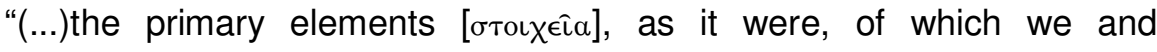

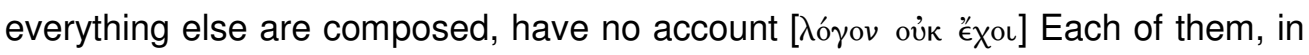

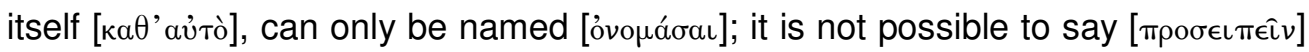

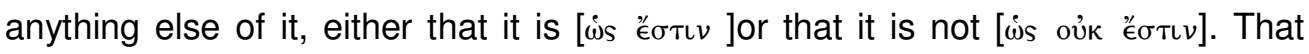
would mean that we were adding being or not-being to it; whereas we must not

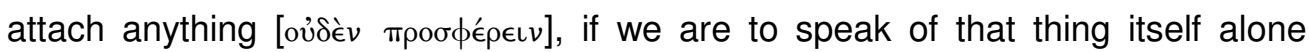

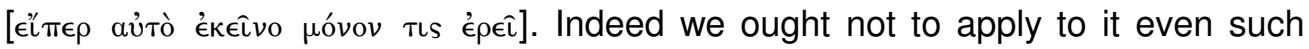
words as 'itself' or 'that', 'each', 'alone', or 'this', or any other of the many words of

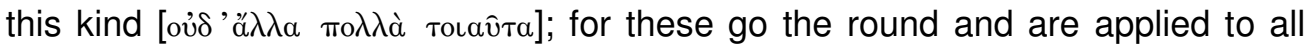

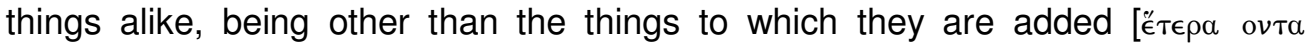

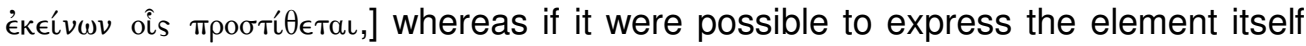

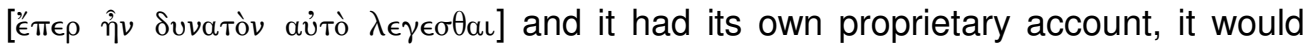

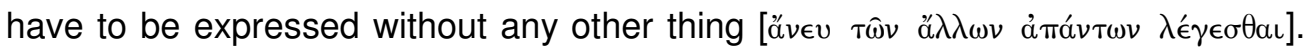
As it is, however, it is impossible that any of the primaries should be expressed in

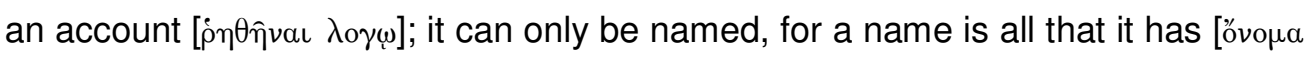

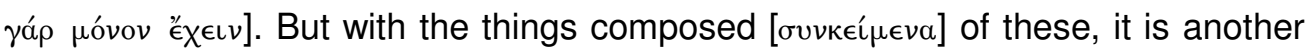
matter. Here, just in the same way as the elements themselves are woven together $\left[\pi \epsilon \in \pi \lambda_{\epsilon \kappa} \tau a l\right]$ so their names may be woven together and become an account of something - an account being essentially a complex of names

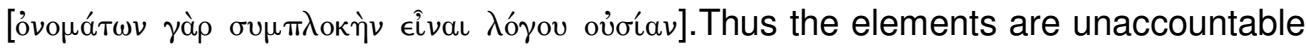

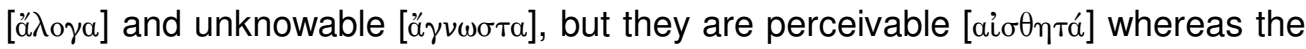

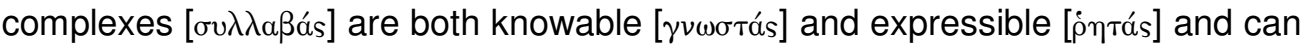
be the objects of true judgment. Now when a man gets a true judgment about something without an account, his soul is in a state of truth as regards that thing, but he does not know it; for someone who cannot give and take an account of a 
thing is ignorant about it. But when he has also got an account of it, he is capable of all this and is made perfect in knowledge". ${ }^{144}$

O texto atribui as seguintes características aos elementos: (i)] não são

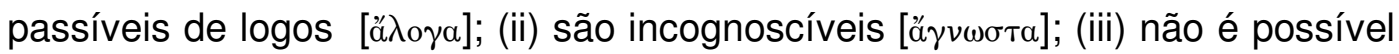
usarmos uma série de palavras para expressar [ $\pi \rho 0 \sigma \epsilon \iota \pi \epsilon \hat{\imath} \nu]$ algo sobre os elementos. Nesse grupo de termos estão: "ser, essência" [ơvoía], "mesmo"

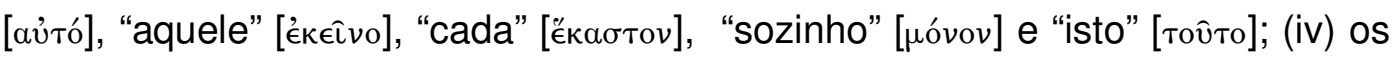
elementos são nomeáveis [ỏvouárau]; (v) os elementos são perceptíveis

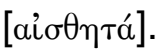

Estas cinco características são condições cognitivas. Por "condição cognitiva" entendo o modo como os elementos podem ser descritos do ponto de vista do conhecimento que se pode ter sobre eles. São condições cognitivas negativas, pois os elementos são analisados aqui de forma isolada, i.e., são lidos sob a perspectiva em que estão desprovidos de vínculos entre si.

O fato de todas as condições atribuídas aos elementos serem negações de um conhecimento genuíno sobre eles não impede que possamos chamar de cognitivas estas condições. Isso pode ser justificado do seguinte modo. $O$ contraste central da teoria - geralmente chamado de assimetria cognitiva, por se tratar de uma tese sobre a não-cognição dos elementos e a completa cognição dos compostos -, é um contraste entre itens cognoscíveis e itens não-cognoscíveis, mas também pode ser visto como um contraste entre duas vias de acesso cognitivo aos mesmos itens, os elementos. Para tanto, deve-se notar que o conceito de composto, onde reside o conhecimento genuíno, conforme a teoria, não é uma categoria absoluta ou discreta. O composto é um composto de elementos. Por isso, em qualquer referência que o autor da teoria fizer aos compostos, ele estará sempre se reportando ao modo como os elementos podem ali ser conhecidos e explicados.

De outro lado, é bastante claro que essa tese da assimetria não é aceita como válida por Platão, pois, além de ser falsa, a crítica à teoria do sonho em

\footnotetext{
${ }^{144}$ A versão de Levett está em Burnyeat (1990: 339). Todas as traduções da terceira parte usadas aqui são comparadas com a versão de Burnyeat-Levett.
} 
203-206 se dirige ao ponto nuclear da assimetria: a alegada incognoscibilidade do elemento. É, portanto, evidente que a teoria do sonho é uma teoria problemática aos olhos de Platão.

Pretendo mostrar que o problema da teoria do sonho é sua concepção de logos. Por meio da análise do conceito de logos na teoria podemos dizer que o autor do Teeteto está exprimindo um argumento sobre a inconsistência de uma tese sobre o conhecimento que atribui cognição ao conceito de composto sem, todavia, observar que a cognoscibilidade dos compostos depende de um conhecimento mais básico. Essa base primitiva do composto também exige conhecimento. Analisemos, primeiro, o conceito de logos da teoria do sonho.

Tudo na teoria do sonho é dito em função da tese de que os elementos não possuem logos, mas não há uma definição clara do significado desse conceito. Podemos obter, no entanto, alguma informação analisando a carpintaria da tese. A forma como aquelas condições que mencionamos se relacionam pode ser descrita da seguinte maneira: (ii) e (iii) são asserções derivadas de (i) e conectadas a esta condição por algumas afirmações feitas em 201e3, a saber: a) os elementos não possuem logos [ $\lambda$ ó si mesmos os elementos só podem ser nomeados; c) não é possível expressar

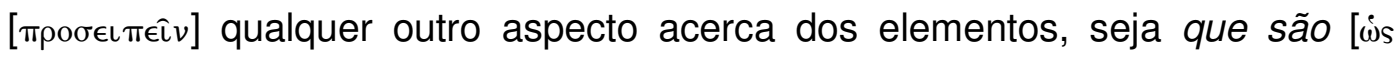

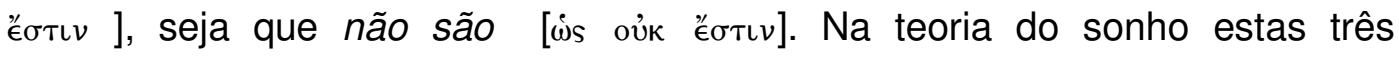
assertivas dão suporte à condição (i), expressa no texto em 201e2-3: os prōta stoicheia não possuem logos.

As condições (iv) (nomeabilidade) e (v) (perceptibilidade) atribuem aos elementos duas características positivas. Podemos conceder nomes aos itens primitivos e se pode ter alguma consciência deles na percepção. Destas duas condições, somente (iv) tem algum amparo em (i), pois não possuir um logos é a razão pela qual o elemento só pode ser nomeado. A nomeabilidade é o resultado de uma restrição na capacidade de se expressar um elemento. Provavelmente o autor da teoria do sonho entende que fornecer um nome aos elementos não implica nenhuma forma de explicação, definição ou uso do elemento numa frase em que o item tenha alguma função independente do que 
ele é em si mesmo. A atribuição de nomes, segundo a teoria do sonho, não envolve nada que não seja peculiar aos elementos. Por isso os nomes estão num contraste com o logos e com a cognição dos elementos

A condição (v), que menciona a perceptibilidade do elemento, nos interessa particularmente. Em contraste com todas as outras, essa condição não tem uma relação óbvia com nada do que constitui os alicerces da teoria. Não é claro o que 'perceptibilidade' de um elemento significa. Em geral os intérpretes ignoram a importância desse aspecto. G. Fine, por exemplo, se refere à perceptibilidade dos elementos como "lame concession", Bostock a considera "inessential" e Burnyeat interpreta a perceptibilidade "as dream theorist's way to secure for elements a momentary "epistemic access". ${ }^{145}$

Creio, contudo, que a perceptibilidade deixará de ser um aspecto tão indesejável se pudermos obter algum esclarecimento sobre o sentido de logos na teoria. Há na base da teoria uma tese sobre o que pode ser expresso ou descrito e o que não pode. Quando os elementos estão numa conexão, eles podem ser expressos, quando não estão, eles são incognoscíveis. Podemos afirmar que a premissa que governa a descrição dos elementos é que eles são inexplicáveis e desprovidos de expressão numa linguagem (exceto para o caso em que se lhes dá um nome) se, e somente se, não há sobre eles nenhum logos. Se pudermos obter algum esclarecimento do sentido desse conceito de logos, podemos interpretar a condição da perceptibilidade de um modo menos evasivo do que tem sido feito na literatura.

Não há uma tradução em português que cubra as possibilidades que o conceito de logos pode ter na teoria do sonho. As várias ocorrências de $\lambda \epsilon ́ \gamma \epsilon \iota \nu$ e seus cognatos indicam que se trata de um sentido básico de expressão de propriedades comuns em oposição à nomeação, algo que o verbo "dizer", como tradução do grego $\lambda{ }^{\prime} \gamma \epsilon \iota v$, não parece conseguir verter facilmente. Veja-

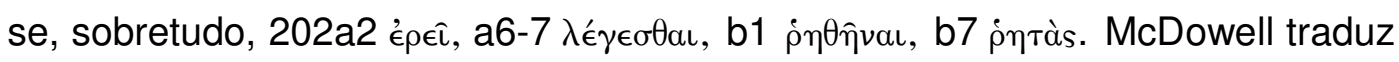
todos estes casos por "to express in an account" (1973). O problema é que há

145 Cf. FINE, 2003: 236; Bostock, 1988, 210; BuRNYEAT, 1990:174-5 e 182. Para uma interpretação mais positiva ver Watanabe , 1987: 152ff e Sedley, 2004: 156ff. Mas estas duas análises oferecem leituras muito controversas da perceptibilidade. 
pelo menos dois sentidos básicos para $\lambda \epsilon ́ \gamma \epsilon \iota v$ : enunciar e definir. ${ }^{146}$ Ambos são adequados para traduzir as instâncias do verbo citadas acima.

Quem defendeu que logos na teoria do sonho significa enunciar uma sentença, em oposição à nomeação ou menção de uma coisa, foi G. Ryle. ${ }^{147}$ Segundo Burnyeat, a interpretação de Ryle é suspeita porque os problemas que Ryle via no texto em $1952^{148}$ são excessivamente inflados pelos temas de Russell e Wittgenstein. ${ }^{149}$ Mas eu acredito que Burnyeat descarta muito rapidamente a análise ryleana. Além disso, seu argumento é controverso. Ele parece sugerir que os problemas discutidos por Ryle são semânticos e, eo ipso, se distanciam dos problemas metafísicos tratados por Platão. Porém, o aspecto semântico em Platão é a parte do conhecimento que implica compreender a relação entre, de um lado, a definição, o logos e o onoma e, de outro, aquilo que está sendo definido, explicado ou nomeado. Nada impede que esse aspecto seja relacionado com os problemas discutidos por Ryle. A análise ryleana da segunda parte do Teeteto, por exemplo, é inteiramente baseada na observação de que a fórmula de identificação entre $x$ e y não exprime o problema do erro. Platão precisa de outro conceito. No texto Platão atribui o problema à doxa, mas um filósofo como Ryle, que está bem informado sobre a história do tema, pode dizer que o problema é a ausência de um tratamento da complexidade da relação entre sentença e referência, questão que recebe no Sofista algum esclarecimento. Ryle está correto ao dizer que esse tratamento ainda não está articulado no Teeteto. O Teeteto se mantém nos limites de uma investigação sobre a idéia de conhecimento enquanto tal. Embora o problema da referência tenha alguma conexão com o tema do

\footnotetext{
${ }^{146}$ cf. Bostock, 1988: 203.

147 RYLE. G., 'Letters and Syllables in Plato', Philosophical Review, 1960, 431-51 e 'Logical Atomism in Plato's Theaetetus', Phronesis, 1990, 21-46.

${ }^{148}$ Foi nesse ano que Ryle leu o texto 'Logical Atomism in Plato's Theaetetus' no Magdalen Coledge, em Oxford, diante de figuras conhecidas como Russell, Miss Murdoch, Kneale, Price, Dodds e W. Hardie, entre outros.

149 Ver a crítica da interpretação de RYLE em BOSTOCK, 1988: 204-11, FINE, 2003: 228-35 e BURNYEAT, 1990: 149-64.
} 
conhecimento, o Sofista e o Crátilo são textos mais adequados para estudar isso.

Minha divergência com Ryle está no fato de que ele ignora o potencial da crítica à teoria do sonho. Platão - não podemos esquecer - está no comando dos detalhes da teoria e argumenta em 206d1-2 que devemos rejeitar a definição de logos que se a fundamenta na simples composição de termos e

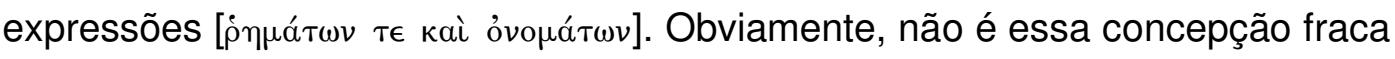
de logos que Ryle está considerando a mais interessante para Platão, pois Ryle tem na sua mira as teses do Sofista que, em sua leitura, anunciam a percepção da distinção entre coisas e predicados gramaticais.

A passagem citada acima, porém, indica que o autor do Teeteto desconfia do arranjo sentencial enquanto tal. Ele diz que qualquer um pode expressar um logos nesse sentido se não for surdo ou mudo desde o momento que expressa

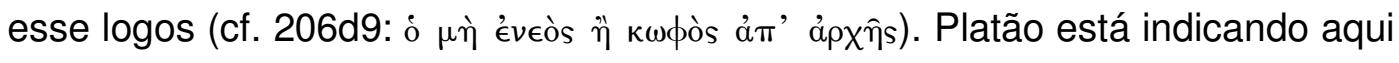
que esse sentido é inócuo como princípio de diferenciação entre logos e opinião verdadeira. Creio que essa passagem é uma objeção indireta ao modo

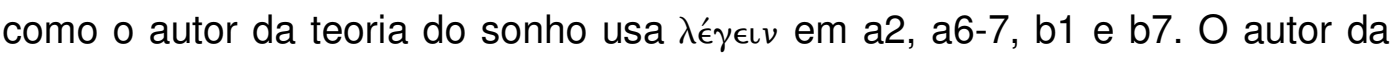
teoria parece argumentar que para um item ser cognoscível é suficiente que expressemos seus vínculos por meio do que ele chama "entrelaçamento de

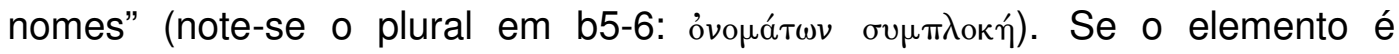
incognoscível porque se trata de um item isolado, o que essa metáfora do entrelaçamento de nomes está propondo? Nos limites do texto da teoria do sonho isso não pode significar outra coisa que uma lista dos nomes que os itens recebem uma vez que estão nos compostos. ${ }^{150}$ Embora eu não possa defender satisfatoriamente isto aqui, penso que Platão está indicando em 206d que a noção de logos como entrelaçamento de nomes não acrescenta muita coisa à definição de logos porque se trata, simplesmente, de uma fórmula verbal sem um conteúdo que expresse um estado de coisas no mundo e se encarregue de ser a condição genuína do saber.

${ }^{150}$ Cf. a excelente análise de MCDowELL, 1973, 232-9. 
Analisemos mais de perto esse conceito de logos como entrelaçamento de nomes. De acordo com o que o autor da teoria parece sugerir em 202b3, para um elemento possuir um logos - no texto isso significa poder ser expresso

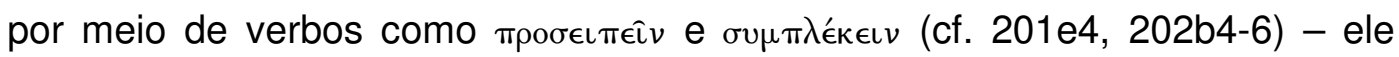
precisa perder sua condição de elemento e se tornar um item conectado a

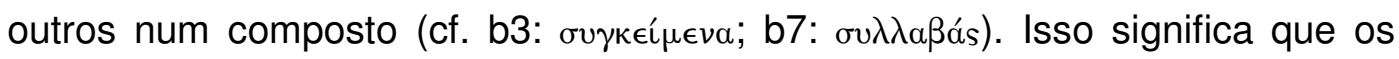
elementos estão sob as condições 1-5 (mencionadas acima) porque a alma (cf. 202c1: భuxí) não é capaz de vê-los sob conexões. Neste caso nossa alma tenta apreendê-los em si mesmos (cf. e3: кaق'aủró). Note-se que não há muita informação aí. Tudo o que a teoria propõe é um contraste entre o que é nomeado (elementos isolados) e o que tem logos (os elementos nos compostos).

Apesar dessa terrível generalidade da carpintaria da teoria do sonho, a crítica parece acreditar que há um conceito claro de logos como expressão peculiar de um item. ${ }^{151}$ Mas é difícil precisar o que isso significa no texto, porque o autor da teoria do sonho não parece ter uma concepção unitária de logos. Defende-se na literatura que o autor da teoria apresenta uma concepção de logos como "oikeios model" (logos peculiar, privado) em 202a7. Essa leitura é proposta por Fine, Bostock e Lee, entre outros. ${ }^{152}$ Segundo Bostock: "the theory very clearly implies that if a thing has a logos (in the relevant sense) then that logos is peculiar to it (202a5-8)." ${ }^{153}$ Mas em 202b3, onde Sócrates completa sua exposição sobre os elementos e começa então a explicar como o autor da teoria entende composto, tal autor parece argüir que logos deve ser definido sob a forma da metáfora da symplokē. Bostock, porém, observa que o oikeios logos é um aspecto sem importância. Ele tem razão, uma vez que o conceito de conhecimento na teoria implica receber um logos e os elementos, tomados em si, são incognoscíveis. Logos é uma condição incompatível com o

\footnotetext{
${ }^{151}$ Ao me deter sobre esse ponto me limito ao que Sócrates relata em 201d-202c. Não me reporto ao criticismo da teoria exposto por Sócrates em 203-206 (argumento do dilema e argumento da experiência).

152 Bostock, 1988: 206SS; FINE, 2003, 240; LEE, 2008, 425.

${ }^{153}$ Bostock , 1988, 206.
} 
nível dos elementos na teoria do sonho. Se o modelo de logos como oikeios é uma condição exclusiva dos elementos, temos uma grave inconsistência na teoria.

Talvez o autor da teoria esteja apenas parcialmente comprometido com o oikeios logos. Penso que o autor da teoria do sonho se ampara num conceito de logos descrito a partir da metáfora da symplokē, citada pela primeira vez em b4 e vertida em b5 como "onomatōn symplokē". ${ }^{154}$ Talvez Bostock, Fine e outros estejam argüindo que o tipo de composto que está em jogo na teoria não permite nenhuma forma de articulação efetiva, i.e., de articulação que exiba o elemento numa condição realmente distinta daquela que ele tem sob o regime de uma enumeração ou adição. Se esse é o caso, Platão estaria mostrando que apesar de logos implicar certa concepção de entrelaçamento de nomes, o conceito de logos da teoria é deficiente porque não percebe distinções nessa categoria. À luz do problema dos pensadores na velhice, (cf. Sofista 251a-c), isso poderia ser lido como uma menção, no Teeteto, à idéia de logos como identidade ou identificação entre um grupo de itens dispostos de certo modo, à esquerda, e outro grupo de itens dispostos de certo modo, à direita. ${ }^{155}$

Isso pode ser inteiramente correto, mas há um problema sério aí com o qual precisamos lidar. Na tese da assimetria os elementos são, de um lado, itens isolados, unicamente nomeáveis e perceptíveis e, de outro lado, itens cognoscíveis e explicáveis nos compostos. Se o oikeios model em a7 e a metáfora da symplokē em b5 estão exprimindo a mesma condição, me parece que a tese da assimetria desmorona antes mesmo de ser retomada em 202b5-

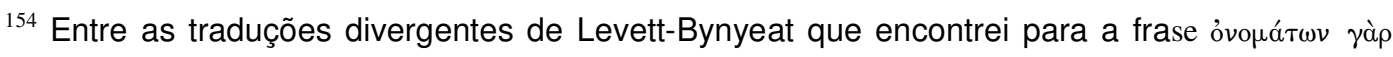

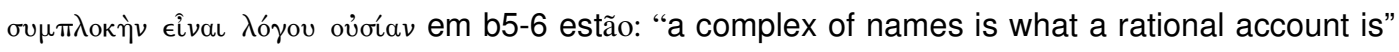
(Chapell, 2004); "car des mots tissés essemble, c'est ce qu'est une definition" (Narcy, 1994); "for a weaving together of names is just what a logos is" (Bostock, 1988); "for the plaiting of names is the being of speech" (Benardete, 1984); "a weaving together of names is the being of an account" (McDowell, 1973); "car la combinaison dont les noms sont formés est l'essence de leur definition" (Chambry, 1967); "a description being precisely a combination of names" (Cornford, 1935).

${ }^{155}$ CORNFORD Defende essa leitura, 1953 [1935], p. 145.
} 
7. Além disso, creio ser claro que logos como oikeios não se adapta aos compostos, enquanto que a metáfora da symplokē é sugerida para fornecer um modo de construí-los. Portanto, se não quisermos nos equivocar acerca do primeiro passo lógico que o autor da teoria está tentando dar, penso que devemos assumir que ele não está exclusivamente comprometido com o conceito de logos como oikeios. O autor da teoria pensa logos sob dois regimes: a) alguma forma de symplokē para os elementos do ponto de vista dos compostos e b) logos como oikeios sob a perspectiva, possível, de alguma descrição mínima dos elementos isolados, i.e., sem conexões. Esta última perspectiva, todavia, não é crucial à teoria.

Se isso está correto, qual é, então, o problema do conceito de logos da teoria do sonho segundo Platão? Esse conceito parece ser válido, já que perfaz exatamente aquilo que $\mathrm{o}$ autor da teoria pretendia, uma distinção entre elementos e compostos do ponto de vista da cognição de ambos.

Existem algumas dificuldades na aceitação do conceito de logos da teoria do sonho como um conceito adequado. Trata-se de um conceito definido pelo contraste com a condição da nomeação dos elementos, mas ele não parece superar o nível classificatório dos elementos (cf. 202a6-7). O autor da teoria tenta estabelecer um critério para a diferença entre a mera nomeação e algo mais substancial em 202b5-6. Trata-se do modelo da symplokē de nomes

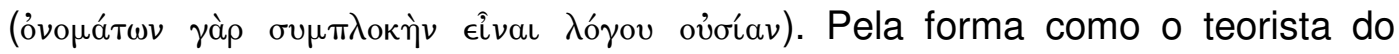
sonho contrasta o oikeios logos e a symplokē de nomes em b6 (övoua yàp... đà

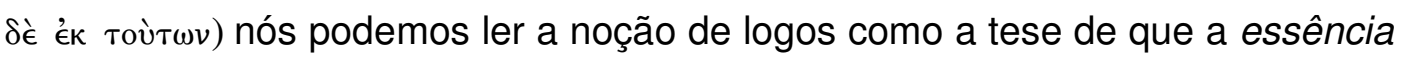
do logos é um complexo de nomes. Assim temos duas condições para retratar os elementos: 1) o oikeios logos como condição cognitiva que um elemento satisfaz somente quando não é conectado a nada mais; $;^{156}$ 2) logos dos elementos sob conexões, não apenas conexões por meio do conceito de ser, como indica o termo ỏvoía em 201e5 e 205c7, mas também conexões a partir

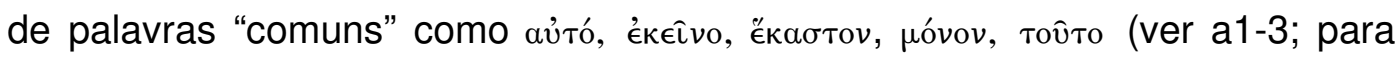

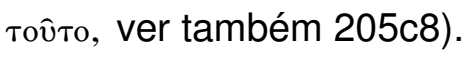

\footnotetext{
${ }^{156}$ Considerando o que é dito em 201e1-3, isso não poderia ser uma noção general de logos.
} 
Mas, como notam Kahn e Fine ${ }^{157}$, esse modelo de symplokē da teoria do sonho não é apropriado. O modelo não exibe a complexidade que leva a alma dos objetos simples aos gêneros quando se trata de expressar o conhecimento. A deficiência do conceito é que ele permanece no nível das relações entre palavras. Nesse nível o critério de diferenciação de objetos e conhecimento não ultrapassa o nível da relação entre coisas e nomes. $O$ discurso aí é um arremedo de "a tal objeto x tal nome y..." e assim por diante.

Devemos concluir que, apesar do fato que a teoria do sonho se vale de uma noção de symplokē, o argumento de Platão consiste em mostrar que essa noção não é suficiente para estabelecer a distinção entre dóxa verdadeira e conhecimento.

$\mathrm{Na}$ tentativa de se escapar dessa conclusão desanimadora sobre o conceito de logos na teoria, muitos argumentam que logos significa "definição". Segundo David Sedley logos na teoria é "a very specific application of the 'definition' one: to indicate an account which analyses a thing by listing its elements." ${ }^{158}$ Há duas possibilidades para esse sentido de logos: 1) análise de itens materiais como barro e carroça (cf. 147a, 206e-208b) em seus componentes básicos; 2) análise de itens logicamente primitivos em temas formais como números, palavras, música e assim por diante.

Burnyeat nomeia estas opções "análise concreta" e "análise abstrata". A primeira é sobre a estrutura de objetos físicos como barro, carroça, etc. A segunda opção focaliza tipos (types) nestas coisas ou em objetos abstratos como números. Nota-se, inclusive, que há uma distribuição desigual de exemplos no texto que se enquadram nos dois casos. Como argumenta Chappell, em 202a-206c Platão fornece cinco exemplos de uma relação do tipo complexo-simples:

\footnotetext{
${ }^{157}$ KAHN, C., 'Why Is the Sophist a Sequel to the Theaetetus?, Phronesis 52 (2007), 33-57, aqui pp. 42-3; FINE, 2003, p. 235.

${ }^{158}$ Sedley, 2004: 153. Sabemos que o teorista do sonho entende análise como lista de itens porque é assim que Sócrates menciona em 206e a noção de logos da teoria do sonho.
} 
In 202a-206c Plato gives five examples of the complex/simple relation. One of Plato's examples does concern relation between 'concrete individual things' (viz the regiment/soldier relation). The other four examples are the syllable/letter relation, the numerical sum/part relation, the musical chord/note relation and the geometrical acre/square foot relation. These examples cannot possibly be taken as concerned with relation between 'concrete individual things'. Syllables and letters, sums and parts, chords and notes, acres and square feet are all types, not concrete particulars. Certainly any instance of these types is a concrete particular, but that is another matter.

No contexto em que tais exemplos são citados, Sócrates não está redefinindo o conceito de análise da teoria do sonho. Ele está interpretando esse conceito, o que destaca o fato de que o conceito de logos da teoria do sonho é um conceito geral. Como nota Bostock: “(...) in all the subsequent illustrations and applications of this theory it is knowledge of a general type, and not a particular individual, that is being discussed."159 Embora na literatura se procure freqüentemente decidir entre duas concepções de logos (definição) para a teoria, (i) análise de itens físicos e (ii) análise de coisas abstratas, não estou convencido de que o autor da teoria do sonho vê estes sentidos como duas espécies distintas de análise. Creio que ele vê como "casos" de um padrão de explicação das coisas que consiste na enumeração de componentes primitivos, sejam formais ou materiais, como forma de mostrar o que é uma coisa. Já vimos que o autor da teoria não possui uma distinção entre o ato de dar nomes e o ato cognitivo de identificar aspectos, relações e pertencimentos. Tudo é interpretado sob a perspectiva da análise como ato de dar nomes. Portanto, o conceito de análise da teoria do sonho não está restrito à análise de coisas físicas e nem restrito à análise de coisas abstratas. É um conceito geral de classificação por meio de palavras de um modo geral.

\subsection{A perceptibilidade dos elementos}

${ }^{159}$ Cf. Bostock, 1988, 242;BURNYEAT 1990: 84-5; CHAPPELL 2005, 219. 
Essa noção de logos como nomeação ou classificação nos preparara para interpretar o problema da percepção dos elementos. Esse problema toma corpo quando o autor da teoria diz que os elementos estão numa condição

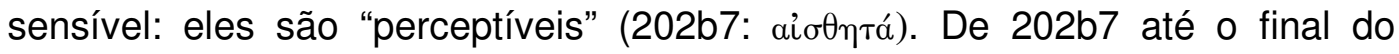
diálogo esta condição não é mais citada. Resta ao intérprete o trabalho de buscar evidências no contexto das teses da teoria do sonho. Já mencionei que há alguma relação mútua nas quatro condições impostas aos elementos, mas no caso da perceptibilidade, parece se tratar de um adendo isolado. Todavia, não podemos ignorar que é uma característica positiva, pois permite à alma alguma forma de acesso sensível aos elementos.

A questão que se impõe é: que forma de acesso uma alma tem pela via da percepção a um item cuja característica básica é não estar conectado ou relacionado a nenhum outro? Quando propõe que os elementos são nomeáveis, nós sabemos que o autor da teoria está tentando garantir um aspecto positivo que não viole a restrição imposta ao uso de expressões comuns para descrever os elementos, como verbos (proseipein e legesthai), gêneros (ousia) e pronomes (ekeino, touto), etc. Quando menciona essa restrição o autor da teoria parece ver um contraste entre palavras que usamos para descrever várias coisas - entre as quais sujeitos e propriedades - e nomes próprios. Contudo, isso não deixa de ser especulativo, pois o autor da teoria não esclarece seu conceito de onoma.

Segundo Cornford o autor da teoria não vê distinção entre a atribuição de nomes sob a forma de um conceito de logos e outras formas de sentenças que se pode enunciar sobre um elemento: "the effect is that the distinction between the definition and other statements about the thing is not drawn". ${ }^{160} \mathrm{O}$ termo "onoma", na língua grega, pode ser definido como uma categoria ampla de palavras, mas o autor da teoria do sonho não pode defender que se trata de uma categoria que inclui termos que podem se referir a outros itens. ${ }^{161}$ Ele não

\footnotetext{
160 CORNFORD, 1935, p. 145.

${ }^{161}$ O uso da expressão "onomata" como uma categoria geral para abarcar "nomes" e "palavras" na língua grega é comum em Platão (cf. FINE, G 'Plato on Naming', in FINE (2003); ACKRILL 'Language and Reality in Plato's Cratylus', in: ACKRILL, Essays on Plato and Aristotle. OUP,
} 
pode violar a restrição mencionada acima. Mas essa restrição se aplica à perceptibilidade? Trata-se de uma tese sobre a consciência do nome de um item sem qualquer forma de articulação ou proposição sobre seu sentido?

No que segue limito-me ao exame da perceptibilidade no tipo de análise que foca itens materiais em compostos físicos. Quero investigar esse conceito porque desejo contestar uma interpretação da relação entre a primeira e a terceira parte do Teeteto. Não vou discutir outras acepções de perceptibilidade, o que exigiria um estudo mais detalhado. Quero, contudo, dizer de modo um tanto dogmático que não vejo a condição da perceptibilidade dos elementos como uma condição cognitiva restrita a itens físicos. Pode ser também uma condição cognitiva como um estado mental sobre dados que não estão na percepção atual. Estou interpretando o conceito de definição da teria do sonho como um conceito bruto de classificação: tal item tem tais e tais características. Definir é expressar um complexo de nomes (cf. 202b5-6). Mas ser unicamente perceptível pode também significar um modo de apresentação "intuitiva" do item. Essa linha "kantiana" merece ser desenvolvida, mas não vou fazê-lo aqui.

Suponhamos que o autor da teoria do sonho está pensando numa análise de compostos físicos. Neste caso seu conceito de conhecimento se torna bastante limitado: conhecimento é listar partes elementares em compostos físicos. Em relação à perceptibilidade dos elementos, o problema

1997; Williams, B., 'Cratylus Theory of Names', in: Shofield \& Nussbaum, Language and Logos, CUP, 1982; Sedley, Plato's Cratylus, CUP, 2003). Platão conserva dois usos de onoma: onoma em oposição a rhēma (nomes como referentes e verbos como algo que se diz sobre os referentes, cf. Sofista 262a-d) e onoma como categoria ampla que abarca palavras de um modo geral. Note-se que o autor da teoria não se refere a verbos na metáfora da symplokē em 202b4-5 (em 206d, por outro lado, no contexto da crítica à teoria do sonho, especula-se que logos poderia consistir de onomata e rhēmata). Talvez o teorista do sonho se alinhe ao uso amplo de onomata para definir logos, pois esta noção está em contraste com as restrições impostas aos elementos. Mas, de outro lado, no nível dos itens elementares não se pode usar categorias de palavras responsáveis por articulações, especialmente verbos e pronomes. Estaria, portanto, o teorista do sonho trabalhando com duas noções de onomata, uma ampla para o logos dos elementos e outra restrita para os elementos em si mesmos? É difícil decidir isso devido à ambigüidade das condições impostas aos elementos. 
agora é o seguinte. Trata-se de uma forma de apresentação de um objeto físico disponível à alma somente quando o elemento não tem nenhuma função num composto? Sendo a perceptibilidade uma condição restritiva dos elementos, podemos supor que a resposta do autor da teoria é afirmativa. ${ }^{162}$ Mas neste caso o que dizer da ocorrência simultânea da percepção de um item e da visão de sua pertença a uma estrutura? Os elementos podem ser, concomitantemente ${ }^{163}$, membros de um composto e perceptíveis, como as partes de uma carroça no exemplo examinado por Sócrates em 206e-208b. ${ }^{164}$ Do ponto de vista de uma pessoa que conhece "o que é uma carroça", esse conhecimento é um estado mental que consiste em ver claramente como as partes se organizam para formar a estrutura da carroça. ${ }^{165}$ Trata-se de um cenário fácil de imaginar se pensarmos no conhecimento de um fazendeiro ou de um vendedor de peças. Para tais pessoas os materiais que integram o objeto de seu trabalho possuem uma estrutura que eles conhecem bem e nada impede que os componentes destes objetos estejam sempre lá para serem observados da perspectiva dessa estrutura. Isso significa que é difícil imaginar uma situação em que itens pertencentes a uma estrutura são percebidos isoladamente. Não há contraste entre percepção e estrutura no conceito de definição como análise de item físicos, pois os elementos podem ser percebidos na estrutura. Essa objeção, no entanto, só faz sentido se o autor da teoria do sonho limita a perceptibilidade ao nível do logos peculiar (oikeios logos), negado-a no nível da estrutura, pois se ele a expande não haveria problema na concomitância entre perceptibilidade e pertença ao composto. Creio que ele admite o primeiro caso. Mas por que ele limita a perceptibilidade dessa maneira? Em que consiste esta condição de perceptibilidade? É uma sensação bruta?

\footnotetext{
${ }^{162}$ Cf. BURNYEAT, 1990, 182.

163 Obviamente não na mesma percepção, mas na mesma situação de percepção quando se pode olhar para os itens de perspectivas distintas.

${ }^{164}$ Esse aspecto é explorado por BURNYEAT (1990) E FINE (2003).

${ }^{165}$ Ver HARING, E. S., The Theaetetus Ends Well, Review of Metaphysics, 35:3 (1982) pp.509528 , aqui p. 520.
} 
David Sedley argumenta que o autor da teoria do sonho concebe percepção no sentido de sensação de coisas físicas, o que nos lembra o

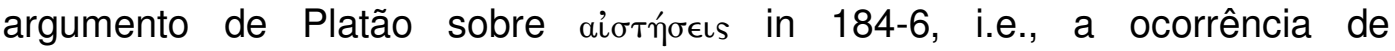
perturbações físicas na alma que, tomadas em si, não passam de impressão pura, sem nenhuma capacidade de articular informações mínimas como "esta rosa é vermelha". Os elementos e os sensíveis da primeira parte estariam, neste caso, partilhando a mesma condição cognitiva. Ambos estão confinados numa noção extremamente limitada de consciência, de modo que sua principal característica é serem itens "não-cognoscíveis". ${ }^{166}$ Segundo Sedley:

It is a commonplace of Platonic thought that what is accessible to the senses is limited to particulars and their properties, while universals, whether at the level of species or genera, are accessible only to the intellect ${ }^{167}$.

Sedley parece sustentar o que segue: para Platão se x é perceptível x é um item acessível aos sentidos e, por isso, se trata de um item particular, não um universal. Portanto, se os elementos da teoria do sonho são perceptíveis, eles não podem ser itens abstratos ou itens gerais, i.e., eles não podem ser uma propriedade geral, apenas instâncias dessa propriedade, como este vermelho específico é uma instância da propriedade vermelho e a febre que sinto é um caso do que se encontra num manual de medicina sob o nome "febre". Se Sedley está certo, o autor da teoria está argüindo que não há acesso cognitivo às instâncias do vermelho, às partes da carroça ou aos sintomas desta febre particular. Dada a tese da assimetria, onde os elementos são vistos sob duas condições cognitivas bem distintas, deve-se então concluir que no nível dos elementos o que uma alma percebe é o que se chama na literatura de "tokens", ocorrências específicas em oposição ao que é comum nas ocorrências (types).

\footnotetext{
${ }^{166}$ Essa conexão entre a primeira parte do diálogo e o texto da teoria do sonho não é nova. Ela foi sugerida nos seguintes trabalhos: CORNFORD (1935), RYLE (1990 [1951]), MEYERHOFF (1958), SAYRE (1969), DESJARDINS (1990) E SEDLEY (2004).

167 SEDLEY, 2004, p. 156.
} 
Sedley não vê distinção entre o que o texto da teoria do sonho argumenta e o que Platão concebe como válido na sensação. Isso é controverso, mas vou ignorar esse detalhe. Em geral, levando-se em conta o que Platão argumenta em 184-6, há de fato a tese de que a sensação estrita ou bruta não envolve a apreensão de aspectos gerais. Mas o contraste de Sedley é forçado. No argumento de 184-6 o contraste é entre a impressão bruta e o conhecimento da impressão (ou de temas abstratos) a partir dos recursos que uma alma é capaz de usar (categorias comuns como ser e as categorias especiais: identidade, diferença, etc.) Já na teoria do sonho o contraste capital é entre itens sobre os quais não há logos/conexão (elementos) e itens sobre os quais há logos/conexão (compostos). Se há um paralelismo implícito entre 184-6 e 201d-202d temos que projetar em 184-6 a tese do sonho. Dessa perspectiva, temos que encontrar em 184-6 a seguinte tese (explícita na teoria do sonho): os sensíveis não possuem logos e as proposições conhecidas ou articuladas pela alma são o logos. A última frase está virtualmente em 184-6, mas Platão não diz nada em 184-6 que implique a primeira. Já a teoria do sonho claramente recomenda a não-cognoscibilidade de seus elementos. Se Sedley está certo, posso inferir o seguinte. Assim como não se deve expressar por meio de verbos e palavras comuns o que um elemento é em si mesmo, também não se deve fazê-lo sobre os dados da sensação, o que, claramente, não é sugerido pelo argumento de 184-6.

A questão aqui depende de se observar o seguinte contraste entre as duas passagens. Há uma tese sobre a simplicidade dos elementos na teoria do sonho e em 184-6 não há nada que se pareça com isso. A tese da simplicidade é uma conseqüência das restrições cognitivas impostas aos elementos. Quanto não é possível limitar mais o núcleo primitivo de um composto, estamos na categoria dos elementos. Há basicamente três categorias de palavras excluídas dos elementos para formar essa condição: gêneros, verbos e pronomes.

Note-se que em 184-6 Platão diz que o conhecimento requer o uso de determinados conceitos sobre os dados da sensação ou sobre os temas nãosensíveis. Em 186d2-5 Sócrates diz: 
Não é naquelas impressões, por conseguinte, que reside o conhecimento, mas no raciocínio a seu respeito; é o único caminho, ao que parece, para atingir a essência e a verdade; de outra forma é impossível. ${ }^{168}$

O que é crucial aqui é nos perguntarmos se 184-6 e a teoria do sonho partilham a tese da simplicidade. Podemos dizer que a tese central de 184-6, cuja conclusão está na passagem acima, é que existem aspectos ou propriedades no mundo que podemos acessar por meio dos sentidos, como os sons particulares e as cores particulares mencionadas em 185b9-c2. De outro lado, há aspectos sobre essas coisas, sua identidade, diferença, oposição, etc., que nós não podemos pensar no nível da capacidade perceptiva. Interpreto essa tese como um tipo de assimetria entre o que pode ser pensado e o que pode ser unicamente sentido. Podemos dizer que a mente tem acesso aos particulares quando se exime de pensar sobre seus aspectos universais. Isso é tudo o que o argumento pode permitir em termos de acesso aos particulares.

Mas note-se que isso não é suficiente para obtermos o nível dos elementos na teoria do sonho. Lá precisamos de uma premissa adicional: se um item não pode mais ser decomposto então ele é um elemento. Em 184-6 Sócrates não precisa dessa tese para desenvolver o argumento. Tudo o que se requer é a premissa: para se pensar, articular ou expressar propriedades é necessário um trabalho intelectual da alma e a sensação não participa disso. Nada aí proíbe, no entanto, que o dado da sensação seja composto.

O que Sedley precisa provar é que a condição da sensação em 184-6 e a condição dos elementos é essencialmente a mesma. Mas isso é extremamente difícil porque a "simplicidade" dos elementos decorre diretamente de sua condição de aloga e do fato de não se poder mais identificar partes primitivas, enquanto que em 184-6 a não cognoscibilidade dos sensíveis é uma potência que os dados sensíveis não possuem, não uma

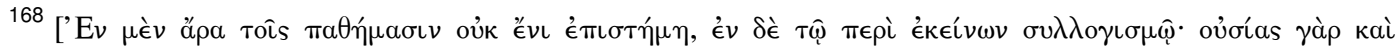

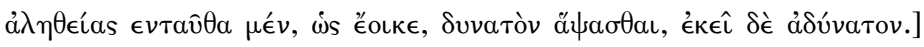


negação do conhecimento de seus aspectos. Penso que 184-6 não defende a tese de que os sensíveis são incognoscíveis, uma condição que está no núcleo da concepção de elemento da teoria do sonho. O argumento de 184-6 defende a tese de que os sensíveis não participam na cognição, o que é uma afirmação muito diferente.

A moral de 184-6 é que se é o caso de pensarmos acerca do sensível isto ou aquilo, então é também o caso de já não podermos tê-los na alma sob a perspectiva da percepção bruta. Por isso, concluo que as duas passagens possuem noções distintas de não-cognoscibilidade e não partilham a mesma noção de aloga. Os elementos da teoria do sonho não são, portanto, exclusivamente itens sensíveis. Eles estão numa condição de generalidade: podem ser letras, peças mecânicas, elementos da natureza, soldados, medida de agricultura, números, e assim por diante.

\section{CONSIDERAÇÕES FINAIS}

Em sua estrutura o Teeteto exibe a forma crítica dos diálogos socráticos, combinada com algumas teses maduras de Platão, como a crença na distinção entre opinião e conhecimento, a crítica à sensibilidade na cognição e o conceito de ousia.

No presente trabalho procurei identificar no diálogo o núcleo da posição platônica sobre a distinção entre razão e sensação. Considerei que o objetivo de Platão, na primeira parte, é mostrar que é possível argumentar a tese de que a percepção é cognitiva, mas, para tanto, é preciso provar que o mundo está estruturado de uma forma que permite à percepção a descrição válida da realidade. O argumento em 151-60 se ocupa da articulação dessa posição, mas a intenção é explorar os limites dessa tese por meio da crítica da teoria epistemológica que o argumento propõe. A estratégia desse exame na primeira parte é dialética. Platão tem um apreço pelo método dialético porque este método lhe fornece o que é necessário para descrever os detalhes da tese sob 
exame. Quando o texto de Platão se envolve na crítica à tese, o leitor já está bastante familiarizado com as articulações da doutrina, sobretudo com a tese da infalibilidade, e não terá dificuldades para compreender suas deficiências. Ao criticar Protágoras, Platão deseja provar que não é possível à sensação conhecer, pois o conhecimento exige objetos estáveis, algo que a tese protagoreana não pode admitir.

$\mathrm{Na}$ segunda parte do diálogo procurei dar uma interpretação positiva ao argumento "saber e não-saber" (188a-c). Parte significativa da crítica do Teeteto tem dificuldades para associar esse argumento com a filosofia de Platão. Minha interpretação consiste num esforço para relacionar o argumento da segunda parte com um argumento platônico transparente, i.e., um argumento que não oferece seus resultados por via indireta, mas exibe em sua estrutura uma tese objetiva. A tese que identifiquei no argumento é a idéia de que o conhecimento precisa ser efetivo e não pode ser compatível com o erro. Apesar do fato que as análises modernas rejeitam essa tese, creio que ela está no coração da epistemologia de Platão. Não se trata, porém, de uma posição epistemológica ingênua ou de um traço indesejável da tradição cognitiva da filosofia grega. Penso que é uma tese plausível se interpretada do ponto de vista do estado mental que define o saber. Essa definição constitui o objeto do Teeteto.

Por fim, creio que minha análise da teoria do sonho oferece alguma novidade à literatura atual dessa parte do diálogo. Os problemas discutidos na literatura sobre a terceira definição são muitos e eu não cheguei a mencionar nem a metade. Meu foco foi muito específico. Tentei entender a carpintaria do texto da teoria do sonho a partir daquilo que Sócrates atribui ao autor da teoria, mesmo sabendo que o autor, no fundo, é o próprio Platão. Mas, ao contrário da segunda parte, na descrição da teoria do sonho Platão claramente não se envolve com o argumento principal, a posição epistemológica que chamei de "assimetria cognitiva". Em minha análise procurei mostrar que há um conceito de logos na teoria que, segundo Platão, é insuficiente. Esse conceito concebe uma forma padrão de análise que consiste na enumeração e classificação por meio de nomes. Os problemas da perceptibilidade dos elementos são discutidos no contexto em que essa definição de logos é o pano de fundo. 


\section{BIBLIOGRAFIA (SELECIONADA)}

Edições críticas do Teeteto

DIÈs. A. Théétète. Tradução francesa e edição crítica por Auguste Diés. Paris: Les Belles Lettres, 1926.

Plato, Opera, I, Ed. Duke, Hicken, Nicoll, Robinson e Strachan. Oxford: OUP, 1995.

Traduções do Teeteto

BenARDETE, S., Plato's Theaetetus: part I of The Being of the Beautiful. Chicago/London: UCP, 1984.

Chambry, E. Théétète. Tradução francesa de Émile Chambry. Paris: Flammarion, 1967.

DIĖs, A. Théétète. Tradução francesa de Auguste Diés.Paris: Les Belles Lettres, 1926.

LeVETt, M. J., in: BuRnYEAT, M. F., The Theaetetus of Plato. Hackett:

Cambridge/Indianapolis, 1990.

McDowell, J. Plato Theaetetus. Tradução e comentário. Oxford: OUP, 1973.

NARCY, M. Théétète. Tradução francesa, introdução e notas por Michel Narcy.

Paris: Flammarion, 1994.

NunEs, C. A., Teeteto-Crátilo. Belém: EDUFPA, 2001 [1973].

Nogueira, A. M., \& Boeri, M, Teeteto. Lisboa: Calouste Gulbenkian, 2005.

Traduções dos diálogos de Platão.

COOPER, J. (Ed.), Plato Complete Works. Indianapolis: Hackett, 1997.

Edições de textos de Aristóteles

JAEGER, W. Aristotelis Metaphysica. Oxford: OUP, 1957. 
HaCKHAM, H., Ed. e Trad., Aristotle Nicomachean Ethics. London: HUP (Loeb), 2003 [1926].

Comentários sobre o Teeteto, Platão e Platonismo

Ackrill, J. L. Essays on Plato and Aristotle. Oxford: OUP (OCT), 2007.

'Plato and the Copula: Sophist 251-259', The Journal of Hellenic Studies, Vol. 77, Part 1 (1957), pp. 1-6

Allen, R. E., 'Participation and Predication in Plato's Middle Dialogues', The Philosophical Review, Vol. 69, No. 2 (1960), pp. 147-164.

Armstrong, D. M., Belief, Truth and Knowledge. Cambridge: CUP, 1973.

AnGIONI, L., Introdução à Teoria da Predicação em Aristóteles. Campinas, Editora da Unicamp, 2006.

Aubenque, P. (dir.), Etudes Sur Le Sophiste de Platon. Paris: Bibliopolis, 1991

BARTON, D. 'The Theaetetus on how we think', Phronesis, v. XLIV/3, 1999.

BenARDETE, S. Plato's Theaetetus: part I of The Being of the Beautiful. Chicago and London: UCP, 1984.

Benson, H. 'Why Is There a Discussion of False Belief in the 'Theaetetus?',

Journal of the History of Philosophy, 30:2 (1992), pp. 171-199.

BLuck, 'Knowledge by Acquaintance' in Plato's Theaetetus' Mind, New Series, Vol. 72, No. 286. (1963), pp. 259-263

Bobonich, C. Plato's Utopia Recast. Oxford: Clarendon Press, 2002.

Bostock, D., Plato's Theaetetus. Oxford: OUP, 1988.

'Plato on "Is-not" (Sophist 254-9)', OSAP 2, 1984, 89-119

Brown, L., 'Understanding the Theaetetus'. A discussion of David Bostock,

Plato's Theaetetus, and Myles Burnyeat, The Theaetetus of Plato", OSAP 11, 1993, 199-224.

'Being in the Sophist: a syntactical enquiry', OSAP, 4 (1986), 49-70

'The Sophist on Statements, Predication, and Falsehood', in The Oxford

Handbook of Plato, ed. by G. Fine, OUP, 2008, pp. 437-462.

BURNYEAT, M., The Theaetetus of Plato, revisão da tradução e introdução por

M. Burnyeat. Indianápolis/Cambridge: Hackett, 1990.

'Plato on the Grammar of Perceiving', Classical Quarterly, Vol 26, n. 1 (1976) pp. 29-51. 
'Socrates and the Jury: Paradoxes in Plato's Distinction between knowledge and True Belief, Part I', Proceedings of the Aristotelian Society, suppl. 54 (1980), pp. 173-191.

'Idealism and Greek Philosophy: what Descartes Saw and Berkeley Missed', The Philosophical Review, Vol. 91, No. 1. (1982), pp. 3-40.

'Examples in Epistemology: Socrates, Theaetetus and G. E. Moore', Philosophy, Vol. 52, №. 202, (1977), pp. 381-398.

'Protagoras and Self-refutation in Later Greek Philosophy' Philosophical Review 85 (1976), 44-69;

'Protagoras and Self-refutation in Plato's Theaetetus', Philosophical Review 85, 172-95;

CAmpBelL, L. The Theaetetus of Plato. Revisão do texto grego e notas em inglês por Lewis Campbell. Oxford: Clarendon Press, 1980 [1883].

CHAPPELL, T. Reading Plato's Theaetetus. Indianápolis/Cambridge: Hackett, 2005.

CHERnISS, H., 'The Philosophical Economy of the Theory of Ideas', American Journal of Philology 57 (1936), 445-456.

'The Relation of the Timaeus to Plato's Later Dialogues', The American Journal of Philology, Vol. 78, No. 3. (1957), pp. 225-266

Crivelli, P., 'AlLODOXIA', Archiv Fur Geschichte Der Philosophie 80 (1998), 1-29.

'Plato's Waxen Block' In Ideal and Culture of Knowledge in Plato, W. Detel, A. Becker, and P. Scholz (eds.). Stuttgart: Franz Steiner Verlag, 2003, pp. 175-200.

Crombie, An Examination of Plato's Doctrines, vol. II. New York, Routledge \& Kegan Paul, 1963.

CoOPER, J. M., 'Plato on Sense-Perception and Knowledge' (Theaetetus 184-6), Phronesis, 15 (1970), 123-146, reimpresso in IRWIN, T., (ed.), Plato's Metaphysics and Epistemology, New York \& London, Garland Publishing, 1995.

CORNFORD, F. Plato's Theory of Knowledge. London: Routledge \& Kegan Paul LTD, 1953 [1935]

Cross, R., 'Logos and Forms in Plato', Mind, Vol. 63, N. 252. (1954), pp. 433450. 
Crowley, T. J., 'On the Use of Stoicheion in the Sense of Element', OSAP, vol. 24 (2005), pp. 367-394.

DAY, J. M., 'The theory of perception in Plato's Theaetetus', OSAP 15, 1997, 5180.

DESJARDINS, R. The Rational Enterprise: logos in Plato's Theaetetus. New York: Suny Series in Ancient Greek Philosophy, 1990.

FINE, G. 'Knowledge and True Belief in The Meno', OSAP 27 (2004), pp. 41-81 (ed.) Plato 1: Metaphysics and Epistemology. Oxford: OUP, 1999. Plato on Knowledge and Forms, Oxford: Clarendon Press, 2003 On Ideas: Aristotle's Criticism of Plato's Theory of Forms. Oxford: OUP, 1993.

The Oxford handbook of Plato (ed.). Oxford: OUP, 2008.

'Plato's Refutation of Protagoras in the Theaetetus', Apeiron 31/3, 1998, 20134.

Plato on Perception', OSAP 1988 (suppl. Vol.), 15-28

Frede, M., 'Observations on Perception in Plato's Later Dialogues', in: IRWIN, 1995, pp. 389-394.

'Being and Becoming in Plato', OSAP Supplementary Volume 1988, 37-52 'Plato's Sophist on False Statements', in Cambridge Companion to Plato, ed. by R. Kraut, CUP, 1990, 397-424.

GEACH, P., Logic Matters . Oxford: Blackwell, 1972.

GentZler, G. (ed.) Method in Ancient Philosophy. Oxford: OUP, 2007.

Gerson, L. P., Knowing Persons: a study in Plato. Oxford \& New York, OUP, 2003.

Grice, H. P., \& White, A. R., 'The Causal Theory of Perception', Proceedings of the Aristotelian Society, Supp. Vol. 35 (1961), pp. 121-168.

HACKFORTH, 'Platonic Forms in the Theaetetus', The Classical Quarterly, New Series, Vol. 7, No. 1/2, 1957, pp. 53-58.

Hamlyn, D. W., 'The Communion of Forms and the Development of Plato's Logic', The Philosophical Quarterly, Vol. 5, No. 21. (1955), pp. 289-302

HARING, E. S., 'The Theaetetus Ends Well', Review of Metaphysics 35 (1982), 509-528.

HARTE, V. Plato on Parts and Wholes. Oxford: Clarendon Press, 2002.

HeIDEgGer, The Essence of The Truth. New York/London: Continuum, 2002. 
Concepts Fondamentaux de la Philosophie Antique, tradução do alemão por Alain Boutot. Paris: Gallimard, 2003

HINTIKKA, J., 'Time, Truth, and Knowledge in Ancient Greek Philosophy', American Philosophical Quarterly, vol. 4, 1967, pp. 1-14

Hochberg, H., 'Nominalism, Platonism and "Being True of"', Nous, vol. 1, n. 04 (1967), pp. 423-419.

Holland, A. J. 'An Argument in Plato's Theaetetus: 184-6', The Philosophical Quarterly, Vol. 23, No. 91. (1973), pp. 97-116

IRWIN, T., (ed.), Plato's Metaphysics and Epistemology, New York \& London, Garland Publishing, 1995.

'Plato's Heracleiteanism', The Philosophical Quarterly 27 (1977), 23-35.

Plato's Ethics. Oxford; OUP, 1995.

Joubaud, C., Le Corps Humain dans la Philosophie Platonicienne. Paris: J. Vrin, 1991.

KaHN, C. "Some Philosophical Uses of 'to be' in Plato", Phronesis, vol. 26, no 2/1981, 105-134.

'Why Is the Sophist a Sequel to the Theaetetus?', Phronesis 52 (2007), 3357.

'Retrospectiva do Verbo Ser e do Conceito de Ser', in: Sobre o verbo grego ser e o conceito de ser. Trad. Maura Iglesias e al. Rio de Janeiro: Núcleo de Estudos de Filosofia Antiga, Departamento de Filosofia da PUC-RJ, 1997, pp. 155-195,

KanaYAmA, Y., "Perceiving, Considering, and Attaining Being (Theaetetus 1846)', OSAP 1987, 29-81

LEE, M. K. Epistemology after Protagoras: responses to relativism in Plato, Aristotle and Democritus. Oxford: Clarendon Press, 2005.

'The Theaetetus', in: G. FINE, 2008, pp. 411-436.

LockWOOD, M., 'On Predicating Proper Names', Philosophical Review, 84, 1975, 471-498.

LORENZ, H., The Brute within. Oxford: OUP, 2006.

MARQUES, M. Platão, pensador da diferença. Belo Horizonte: Editora UFMG, 2006.

MAson, A. 'The Good, Essences and Relations', in Pursuing the Good: Ethics and Metaphysics in Plato's Republic, ed. by Cairns, D., Herrmann, F. G., and 
Penner, T., Edinburgh Leventis Studies 04, 2007.

MCDOWELL, J., Plato Theaetetus. Oxford: OUP, 1973.

'ddentity Mistakes: Plato and the Logical Atomists', in FINE (ed.), 1999.

MeYERHOFF, J., 'Socrates "Dream" in the Theaetetus', Classical Quarterly 8 (1958), 131-8.

MODRAK, D., 'Plato: a theory of perception or a nod to sensation?' in BENSON,

H. (ed.), A Companion to Plato. Blackwell Publishing, 2006, pp. 133-45

Moravsick, J., Platão e Platonismo. São Paulo, Loyola, 2006.

MOLINE, J. Plato's Theory of Understanding. Wisconsin: The University of

Wisconsin Press, 1981.

NAKHINIKIAN, G., 'Plato's Theory of Sensation', Review of Metaphysics, 9 (1955/1956) 129-148.

Nehamas, A. Virtues of Authenticity. New Jersey: PUP, 1998.

"Confusing Universals and Particulars in Plato's Early Dialogues" The Review of Metaphysics, Vol. 29, No. 2 (1975), pp. 287-30.

NARCY, M. (Org.), Platon, l'amour du savoir. Paris, PUF, 2001.

OWEN, G. E. L., Logic, Science, and Dialectic, ed. por Martha Nussbaum. NY, Cornell University Press, 1986.

'A Proof in the П€िì I $\delta \epsilon \hat{\omega} v '$ ', The Journal of Hellenic Studies, Vol. 77, (1957),

pp. 103-111;

'The Place of the Timaeus in Plato's Dialogues', The Classical Quarterly, Vol. 3, No. 1/2 , 1953, 79-95.

Pradeau, Jean-Françols (Coord.), Platon: Les Formes Intelligibles, Paris: PUF RoBinson, R. 'Forms and Error in Plato's Theaetetus', The Philosophical

Review, Vol. 59, No. 1., 1950.

Plato's Earlier Dialectic. Oxford: Clarendon, 1953.

RuE, R., 'The Philosopher in Flight: the Digression (172c-177c) in Plato's

Theaetetus', Oxford Studies in Ancient Philosophy, 11 (1993), pp. 71-100

RusseLL, B. Logic and Knowledge, ed. R. C. Marsh. London, 1956.

'Perception', Journal of Philosophical Studies, Vol. 1, No. 1 (Jan., 1926), pp. 78-86.

History of Western Philosophy (London: George Allen \& Unwin LTD, 1957.

The Problems of Philosophy. Oxford: OUP, 2001

RyLE, G., 'Letters and Syllables in Plato', Philosophical Review (1960), 431-51. 
'Logical Atomism in Plato's Theaetetus', Phronesis (1990).

'Plato's Parmenides', Mind 48 (1939), 129-51

SAYRE, K., Plato's Late Ontology: a riddle resolved, with a new introduction.

Parmenides Publishing, 2005.

Plato's Analytic Method. Chicago: University of Chicago Press, 1969.

Belief and Knowledge, Rowman \& Littlefied Publishers, 1997

SCHOFIELD, M. (Ed.), Language and Logos: studies in ancient greek philosophy presented to g.e.l owen. Cambridge \& New York:

Cambridge University Press, 1983.

ScotT, D. Recollection and Experience. Cambridge: CUP, 1995.

SedLeY, D. The Midwife of Platonism. Oxford: Clarendon Press, 2005

Stern, P., Knowledge and Politics in Plato's Theaetetus. New York: CUP, 2008

TAYLOR, A. E., The Man and His Work. New York, Dover, 2001 [1937].

VLAStOS, G. (Ed.), Plato I: collection of critical essays. New York, D. \& C., 1971.

WAtANABE, K., 'The Theaetetus on Letters and knowledge', Phronesis, Vol 32, n. 02 (1987), 143-164.

WILLIAMS, C. J. F., 'Referential Opacity and False Belief in the Theaetetus', The Philosophical Quarterly, Vol. 22, No. 89. (972), pp. 289-302.

WHITE, N. P., Plato on Knowledge and Reality. Indianapolis \& Cambridge, Hackett, 1976;

A Companion to Plato's Republic. Indianapolis \& Cambridge, Hackett, 1979.

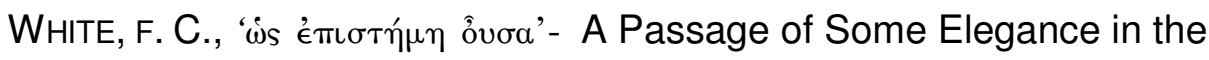

Theaetetus', Phronesis 17, 1972, 219-226

ZINGANO, M. (Org.), Sobre a Metafísica de Aristóteles: textos selecionados.

São Paulo, Odysseus Editora, 2005.

"Auto-Predicação, Não-Identidade, Separação", Analytica vol. 3, n. 2, 1988, pp. 241-259. 